ISBN 978-623-6833-61-2 (PDF)

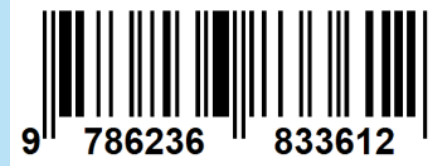

SISTEM INFORMASI

AKUNTANSI \& MANAJEMEN

Imelda Dian Rahmawati, SE., Ak., M.Ak.CA

Ir. Sumarno, MM

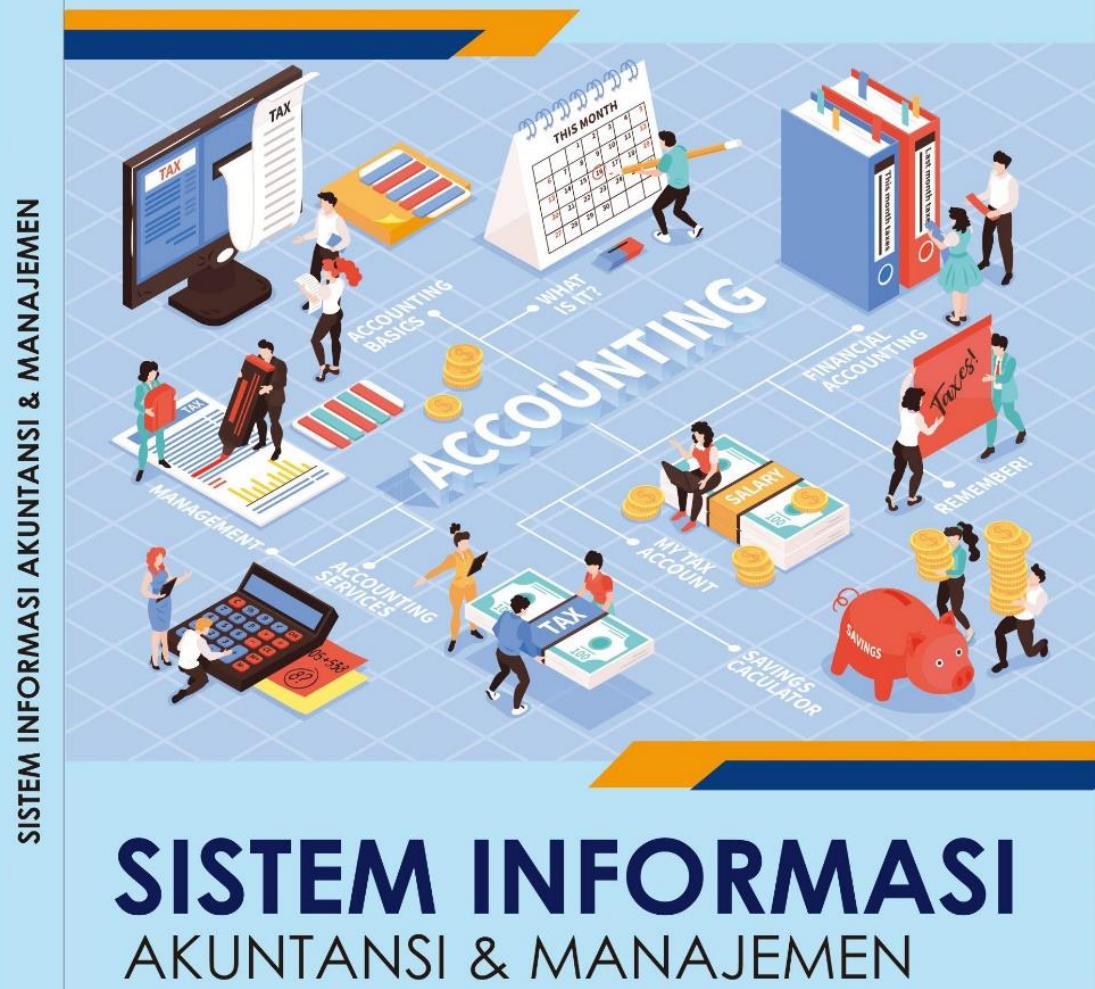

(UP) Imelda Dian Rahmawati, SE., Ak., M.Ak.CA Ir. Sumarno, MM 


\section{BUKU AJAR \\ SISTEM INFORMASI AKUNTANSI DAN \\ MANAJEMEN}

Oleh

Imelda Dian Rahmawati.,SE.Ak.M.Ak.CA

Ir. Sumarno, MM.

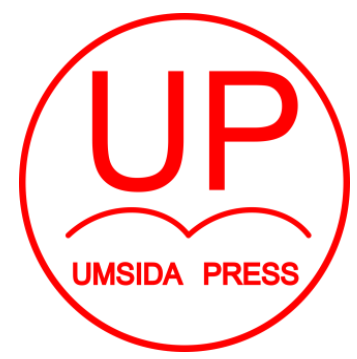

UNIVERSITAS MUHAMMADIYAH SIDOARJO

2020 


\section{BUKU AJAR \\ SISTEM INFORMASI AKUNTANSI DAN MANAJEMEN}

\section{Penulis:}

Imelda Dian Rahmawati.,SE.Ak.M.Ak.CA

\section{ISBN :}

978-623-6833-61-2

\section{Editor:}

Sarwendah Biduri.,SE.MSA

\section{Design Sampul dan Tata Letak:}

Mochammad Nashrullah, S.Pd.

Yoga Ammy Prajati, S.Kom.

Penerbit:

UMSIDA Press

Anggota IKAPI No. 218/Anggota Luar Biasa/JTI/2019

Anggota APPTI No. 0020181092017

Redaksi

Universitas Muhammadiyah Sidoarjo

Jl. Mojopahit No 666B

Sidoarjo, Jawa Timur

Cetakan Pertama, September 2020

(CHak Cipta dilindungi undang undang

Dilarang memperbanyak karya tulis ini dengan sengaja, tanpa ijin tertulis dari penerbit. 


\section{KATA PENGANTAR}

Puji syukur kehadirat Allah swt atas terselesaikannya buku ajar ini. Buku ajar ini disusun dilatarbelakangi saat ini kita berada pada zaman tekhnologi informasi digital atau dengan kata lain kita masuk dalam desruption era 4.0. Salah satu upaya memasuki era tersebut prodi akuntansi mengadakan lokakarya kurikulum, hasil dari lokakarya tersebut salah satunya adalah menggabungkan matakuliah sistem informasi manajemen dan sistem informasi akuntansi menjadi satu mata kuliah dengan nama Sistem Informasi Akuntansi dan Manajemen. Dengan harapan mahasiswa mendapatkan bekal pengetahuan dan wawasan tentang sistem informasi secara sistematis dan terintegrasi antara tinjauan sistem informasi manajemen dan sistem informasi akuntansi. Capaian dari mata kuliah ini diharapkan mahasiswa bisa memahami sistem informasi manajemen dan akuntansi perusahaan beserta aplikasi yang ada untuk memudahkan dalam pengambilan keputusan yang dilakukan oleh manajer dan akuntan perusahaan. Pengambilan keputusan menjadi semakin mudah, akurat, lengkap dan tepat, dapat dipercaya karena semua dilakukan dengan transparan dan akuntabel dengan menggunakan tekhnologi informasi.

Akhirnya saya sampaikan terimakasih atas support dan dukungan semua pihak atas terselesaikannya buku ajar 
ini. Selanjutnya semoga buku ajar ini bisa memberikan manfaat berarti pada mahasiswa dan sejawat sehingga bisa memperkaya hasanah ilmu pengetahuan di Indonesia. 


\section{COVER}

\section{KATA PENGANTAR}

DAFTAR ISI

\section{BATANG TUBUH}

\section{BAB 1 KONSEP DASAR SISTEM INFORMASI}

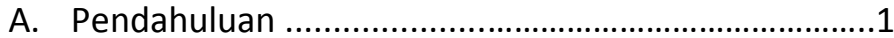
B. Konsep Dasar Sistem dan Informasi ...................2
C. Karakteristik dan Klasifikasi Sistem Informasi.....3
D. Peran Sistem Informasi....................................5
E. Sistem Informasi Manajemen (SIM) \& Sistem Informasi Akuntansi (SIA).................................6

\section{BAB 2 SISTEM MANAJEMEN DATABASE}
A. Pendahuluan....................................................14
B. Manfaat Sistem manajemen basis data.............15
C. Komponen Utama DBMS............................16
D. Keuntungan dan Kerugian Sistem Manajemen

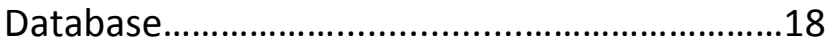
E. Proses Menciptakan Database.........................21 


\section{BAB 3 ANALISIS DAN PENGEMBANGAN SISTEM INFORMASI}
A. Pendahuluan
25
B. Pengertian Analisis Sistem 26
C. Tugas Analis Sistem 28
D. Tujuan dan Fungsi Analisis Sistem .29
E. Langkah - Langkah Analisa Sistem 30
F. Analisis Kelemahan Sistem Dan Laporan Hasil Analisis Sistem.

\section{BAB 4 SISTEM INFORMASI PEMASARAN}
A. Pendahuluan 34
B. Pengertian Sistem Informasi Pemasaran .35
C. Komponen - Komponen Dasar Sistem Informasi Pemasaran.
D. Peran Sistem Informasi Pemasaran 38
E. Model Sistem Informasi Pemasaran 40

\section{BAB 5 SISTEM INFORMASI SDM}
A. Pendahuluan
49
B. Pengertian Sistem Informasi Sumber Daya Manusia.... .50
C. Fungsi dan Tujuan Sistem Informasi Sumber Daya Manusia 51


D. Kegunaan Sistem Informasi Sumber Daya

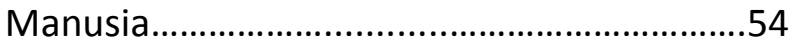

E. Model Sistem Informasi SDM..........................56

\section{BAB 6 SISTEM INFORMASI MANUFAKTUR}
A. Pendahuluan
63
B. Pengertian Sistem Infomasi Manufaktur........64
C. Manfaat Sistem Informasi Manufaktur............65
D. Model Sistem Informasi Manufaktur................66
E. Komputer Sebagai Sistem Informasi .72

\section{BAB 7 SISTEM INFORMASI KEUANGAN}

A. Pendahuluan ………………………………....... 80

B. Pengertian Sistem Informasi Keuangan.............81

C. Model Sistem Informasi Keuangan ...................82

D. Sifat Dan Bentuk Sistem Informasi Keuangan...86

E. Fungsi, Tujuan dan Ruang Lingkup Sistem Informasi Keuangan .87 


\section{BAB 8 SISTEM INFORMASI EKSEKUTIF DAN SISTEM PENDUKUNG KEPUTUSAN}
A. Pendahuluan
.94
B. Pengertian Sistem Informasi Eksekutif .95
C. Karakteristik dan Model Sistem Informasi Eksekutif (SIE)
D. Penerapan
SIE
Pada
suatu
Organisasi .98
E. Konsep dan Manfaat Sistem Pendukung Keputusan 100

\section{BAB 9 SISTEM INFORMASI AKUNTANSI}
A. Pendahuluan.......................................................105
B. Pengertian Sistem Informasi Akuntansi..........106
C. Fungsi Sistem Informasi Akuntansi .................107
D. Jenis Sistem Informasi Akuntansi....................109
E. Bagian - Bagian dan Keandalan Sistem Informasi Akuntansi

\section{BAB 10 TEKNIK DOKUMENTASI DAN PENGEMBANGAN SISTEM}

A. Pendahuluan 
B. Pengertian Dokumentasi dan Pengembangan

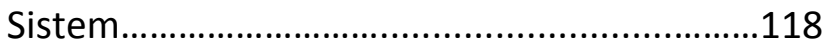

C. Diagram Alir Data (DFD).................................119

D. Data Flowchart (Bagan Alir)...............................121

E. Pengembangan Sistem.....................................124

\section{BAB 11 PENGENDALIAN DAN SISTEM INFORMASI}

\section{AKUNTANSI}

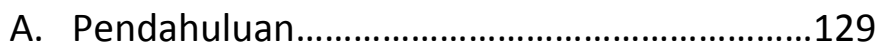

B. Konsep Pengendalian.......................................130

C. Kerangka

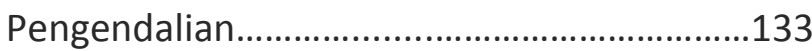

D. Aktivitas

Pengendalian......................................................135

E. Lingkungan Internal.........................................144 
BATANG TUBUH DAN SUB-CAPAIAN PEMBELAJARAN MATA KULIAH

\begin{tabular}{|c|c|}
\hline BAB & SUB-CAPAIAN PEMBELAJARAN MATA KULIAH \\
\hline $\begin{array}{l}\text { BAB } 1 \\
\text { KONSEP DASAR } \\
\text { SISTEM } \\
\text { INFORMASI }\end{array}$ & $\begin{array}{l}\text { Mahasiswa diharapkan untuk mampu : } \\
\text { 1. Memahami konsep dasar sistem } \\
\text { informasi } \\
\text { 2. Menjelaskan karakteristik serta } \\
\text { klasifikasi sistem informasi } \\
\text { 3. Menjelaskan peran sistem informasi } \\
\text { 4. Memahami sistem informasi } \\
\text { manajemen dan sistem informasi } \\
\text { akuntansi }\end{array}$ \\
\hline $\begin{array}{l}\text { BAB } 2 \\
\text { SISTEM } \\
\text { MANAJEMEN } \\
\text { DATABASE }\end{array}$ & $\begin{array}{l}\text { Mahasiswa diharapkan untuk mampu : } \\
\text { 1. Memahami definisi sistem manajemen } \\
\text { database } \\
\text { 2. Menjelaskan manfaat sistem } \\
\text { manajemen database } \\
\text { 3. Menjelaskan komponen utama sistem } \\
\text { manajemen database } \\
\text { 4. Menjelaskan keuntungan dan kerugian } \\
\text { sistem manajemen database } \\
\text { 5. Menjelaskan proses menciptakan } \\
\text { database. }\end{array}$ \\
\hline
\end{tabular}




\begin{tabular}{|c|c|}
\hline $\begin{array}{l}\text { BAB } 3 \\
\text { ANALISIS DAN } \\
\text { PENGEMBANGAN } \\
\text { SISTEM } \\
\text { INFORMASI }\end{array}$ & $\begin{array}{l}\text { Mahasiswa diharapkan untuk mampu : } \\
\text { 1. Memahami definisi analisis sistem dan } \\
\text { analis sistem } \\
\text { 2. Menjelaskan tugas analis sistem } \\
\text { 3. Menjelaskan tujuan dan fungsi analisis } \\
\text { sistem } \\
\text { 4. Menjelaskan langkah-langkah analisa } \\
\text { sistem } \\
\text { 5. Menjelaskan cara menganalisis } \\
\text { Kelemahan Sistem Dan membuat } \\
\text { Laporan Hasil Analisis Sistem }\end{array}$ \\
\hline $\begin{array}{l}\text { BAB } 4 \\
\text { SISTEM } \\
\text { INFORMASI } \\
\text { PEMASARAN }\end{array}$ & $\begin{array}{l}\text { Mahasiswa diharapkan untuk mampu : } \\
\text { 1. Memahami definisi sistem informasi } \\
\text { pemasaran } \\
\text { 2. Menjelaskan komponen-komponen } \\
\text { dasar sistem informasi pemasaran } \\
\text { 3. Menjelaskan peran sistem informasi } \\
\text { pemasaran } \\
\text { 4. Menjelaskan model-model sistem } \\
\text { informasi pemasaran }\end{array}$ \\
\hline $\begin{array}{l}\text { BAB } 5 \\
\text { SISTEM } \\
\text { INFORMASI SDM }\end{array}$ & $\begin{array}{l}\text { Mahasiswa diharapkan untuk mampu : } \\
\text { 1. Memahami definisi sistem informasi } \\
\text { SDM }\end{array}$ \\
\hline
\end{tabular}




\begin{tabular}{|c|c|}
\hline & $\begin{array}{l}\text { 2. Menjelaskan fungsi dan tujuan sistem } \\
\text { informasi SDM } \\
\text { 3. Menjelaskan kegunaan sistem informasi } \\
\text { SDM } \\
\text { 4. Menjelaskan model sistem informasi } \\
\text { SDM }\end{array}$ \\
\hline $\begin{array}{l}\text { BAB } 6 \\
\text { SISTEM } \\
\text { INFORMASI } \\
\text { MANUFAKTUR }\end{array}$ & $\begin{array}{l}\text { Mahasiswa diharapkan untuk mampu : } \\
\text { 1. Memahami definisi sistem informasi } \\
\text { manufaktur } \\
\text { 2. Menjelaskan manfaat sistem informasi } \\
\text { manufaktur } \\
\text { 3. Menjelaskan model sistem informasi } \\
\text { manufaktur } \\
\text { 4. Menjelaskan komputer sebagai sistem } \\
\text { informasi }\end{array}$ \\
\hline $\begin{array}{l}\text { BAB } 7 \\
\text { SISTEM } \\
\text { INFORMASI } \\
\text { KEUANGAN }\end{array}$ & $\begin{array}{l}\text { Mahasiswa diharapkan untuk mampu : } \\
\text { 1. Memahami definisi sistem informasi } \\
\text { keuangan } \\
\text { 2. Menjelaskan model sistem informasi } \\
\text { keuangan } \\
\text { 3. Menjelaskan sifat dan bentuk sistem } \\
\text { informasi keuangan } \\
\text { 4. Menjelaskan fungsi, tujuan dan ruang } \\
\text { lingkup sistem informasi keuangan }\end{array}$ \\
\hline
\end{tabular}




\begin{tabular}{|c|c|}
\hline $\begin{array}{l}\text { BAB } 8 \\
\text { SISTEM } \\
\text { INFORMASI } \\
\text { EKSEKUTIF DAN } \\
\text { SISTEM } \\
\text { PENDUKUNG } \\
\text { KEPUTUSAN }\end{array}$ & $\begin{array}{l}\text { Mahasiswa diharapkan untuk mampu : } \\
\text { 1. Memahami definisi sistem informasi } \\
\text { eksekutif } \\
\text { 2. Menjelaskan karakteristik sistem } \\
\text { informasi eksekutif dan Modelnya } \\
\text { 3. Memahami contoh sistem informasi } \\
\text { eksekutif dalam organisasi } \\
\text { 4. Memahami konsep dan manfaat sistem } \\
\text { pendukung keputusan }\end{array}$ \\
\hline $\begin{array}{l}\text { BAB } 9 \\
\text { SISTEM } \\
\text { INFORMASI } \\
\text { AKUNTANSI }\end{array}$ & $\begin{array}{l}\text { Mahasiswa diharapkan untuk mampu: } \\
\text { 1. Memahami definisi sistem informasi } \\
\text { akuntansi } \\
\text { 2. Menjelaskan fungsi sistem informasi } \\
\text { akuntansi } \\
\text { 3. Menjelaskan jenis sistem informasi } \\
\text { akuntansi } \\
\text { 4. Menjelaskan bagian-bagian dan } \\
\text { keandalan sistem informasi akuntansi }\end{array}$ \\
\hline $\begin{array}{l}\text { BAB } 10 \\
\text { TEKNIK } \\
\text { DOKUMENTASI } \\
\text { DAN } \\
\text { PENGEMBANGAN } \\
\text { SISTEM }\end{array}$ & $\begin{array}{l}\text { Mahasiswa diharapkan untuk mampu: } \\
\text { 1. Memahami definisi dokumentasi dan } \\
\text { pengembangan sistem } \\
\text { 2. Memahami dan menjelaskan data flow } \\
\text { diagram }\end{array}$ \\
\hline
\end{tabular}




\begin{tabular}{|c|l|}
\hline & $\begin{array}{l}\text { 3. Memahami dan menjelaskan data } \\
\text { flowchart } \\
\text { 4. } \begin{array}{l}\text { Menjelaskan teknik pengembangan } \\
\text { sistem }\end{array}\end{array}$ \\
$\begin{array}{c}\text { BAB 11 } \\
\text { PENGENDALIAN } \\
\text { INFORMASI } \\
\text { AKUNTANSI }\end{array}$ & $\begin{array}{l}\text { Mahasiswa diharapkan untuk mampu : } \\
\text { 1. Memahami konsep pengendalian } \\
\text { internal }\end{array}$ \\
& $\begin{array}{l}\text { Memahami dan menjelaskan kerangka } \\
\text { Memahami dan menjelaskan aktivitas } \\
\text { pengendalian } \\
\text { 4. Memahami dan menjelaskan lingkungan } \\
\text { internal pengendalian }\end{array}$ \\
\hline
\end{tabular}




\section{PENDAHULUAN}

Saat ini kita berada pada zaman tekhnologi informasi digital atau dengan kata lain kita masuk dalam desruption era 4.0. Karena itu prodi akuntansi mengadakan lokakarya kurikulum dan melakukan kajian kurikulum yang akan diberikan kepada mahasiswanya. Hasil dari lokakarya tersebut salah satunya adalah menggabungkan matakuliah sistem informasi manajemen dan sistem informasi akuntansi menjadi satu mata kuliah dengan nama ............... Dengan harapan mahasiswa mendapatkan bekal pengetahuan dan wawasan tentang sistem informasi secara sistematis dan terintegrasi antara tinjauan sistem informasi manajemen dan sistem informasi akuntansi. Capaian dari mata kuliah ini diharapkan mahasiswa bisa memahami sistem informasi manajemen dan akuntansi perusahaan beserta aplikasi yang ada untuk memudahkan dalam pengambilan keputusan yang dilakukan oleh manajer dan akuntan perusahaan. Pengambilan keputusan menjadi semakin mudah, akurat, lengkap dan tepat, dapat dipercaya karena semua dilakukan dengan transparan dan akuntabel dengan menggunakan tekhnologi informasi. 


\section{BAB 1}

\section{KONSEP DASAR SISTEM INFORMASI}

\section{Tujuan instruksional}

Dengan membaca bab ini, mahasiswa diharapkan untuk mampu :

1. Memahami konsep dasar sistem informasi

2. Menjelaskan karakteristik serta klasifikasi sistem informasi

3. Menjelaskan peran sistem informasi

4. Memahami sistem informasi manajemen dan sistem informasi akuntansi

\section{A. Pendahuluan}

Informasi di dalam sebuah perusahaan sangat penting untuk mendukung kelangsungan perkembangannya, sehingga terdapat alasan bahwa informasi sangat dibutuhkan bagi sebuah perusahaan. Akibat bila kurang mendapatkan informasi, dalam waktu tertentu perusahaan akan mengalami ketidakmampuan mengontrol sumber daya, sehingga dalam mengambil keputusan-keputusan strategis sangat terganggu, yang pada akhirnya akan mengalami kekalahan dalam bersaing dengan lingkungan pesaingnya. Disamping itu, sistem informasi yang dimiliki seringkali tidak dapat bekerja 
dengan baik. Masalah utamanya adalah bahwa sistem informasi tersebut terlalu banyak informasi yang tidak bermanfaat atau berarti (sistem terlalu banyak data).

\section{B. Konsep Dasar Sistem dan Informasi}

Sistem merupakan kumpulan elemen yang saling berhubungan satu sama lain yang membentuk satu kesatuan dalam usaha mencapai suatu tujuan (Oetomo, 2002). Informasi adalah data yang diolah menjadi bentuk yang memiliki arti bagi penerima dan bermanfaat bagi pengambilan keputusan saat ini atau mendatang (McLeod, 2004).

Informasi dibedakan menjadi dua jenis yakni informasi Formal dan informasi Informal. Ciri-ciri dari Informasi yakni Terbaru, Tepat Waktu, Relevan, Konsisten dan Penyajian dalam bentuk yang sederhana.

Menurut O'Brien \& George M Marakas (2016) Sistem informasi adalah kombinasi terorganisasi apapun dari manusia, perangkat keras, perangkat lunak, jaringan komunikasi, sumber data dan kebijakan serta prosedur yang terorganisasi yang menyimpan, mengambil, mengubah, dan memisahkan informasi dalam sebuah organisasi.

Sehingga dapat disimpulkan bahwa Sistem informasi adalah suatu sistem yang menyediakan informasi bagi semua tingkatan dalam organisasi tersebut kapan saja 
diperlukan. Sistem ini menyimpan, mengambil, mengubah, mengolah dan mengkomunikasikan informasi yang diterima dengan menggunakan sistem informasi atau peralatan sistem lainnya.

Perangkat sistem informasi :

1. Hardware : komputer, printer, dan teknologi jaringan

2. Software

a. Operating System : Windows, Linux, Novell Netware, dll

b. Aplikasi : Ms.Office, GL, Corel Draw, dll

c. Utility : anti virus, Norton Utility, Disk Doctor, dll.

d. Bahasa Pemrograman : V.Foxpro, C++, Pascal, dll.

3. Brainware:

a. Clerical Personnel

b. First Level Manager

c. Staff Specialist

d. Management

4. Data : dokumen bukti transaksi, nota, kuitansi, dsb.

5. Prosedur : Manual book, prosedur sistem pengendalian intern.

C. Karakteristik dan Klasifikasi Sistem Informasi

1. Karakteristik sistem terdiri dari :

a. Komponen/elemen (Component)

b. Batas Sistem (Boundary)

c. Lingkungan Luar (Environment) 

d. Penghubung (Interface)
e. Masukan (Input)
f. Pengolah (Process)
g. Keluaran (Output)
h. Sasaran (Objective) /Tujuan (Goal)

2. Klasifikasi Sistem :

a. Abstract System \& Physical System.

Sistem Abstrak (Abstract System) adalah sistem yang tidak tampak secra fisik, karena hanya berupa pemikiran atau ide-ide. Contoh, sistem Teologia yang merupakan suatu sistem yang menggambarkan hubungan manusia dengan Tuhan.

Sistem Fisik (Physical System) adalah sistem yang tampak secara fisik. Contoh, Sistem Komputer, Sistem Produksi, Sistem Pendidikan dll.

b. Natural System \& Human Made System

Sistem Alamiah (Natural System), adalah sistem yang terjadi dari proses-proses alam. Contoh Sistem Geologi.

Sistem buatan Manusia (Human made system), adalah suatu sistem yang dirancang atau didisain oleh manusia. Contoh Sistem Informasi.

c. Deterministic System \& Probabilistic System 
Sistem Deterministik (Deterministic System), adalah sistem yang beroperasi dengan tingkah laku yang dapat diramalkan. Interaksi antar elemen-elemen dapat diteteksi, sehingga outputnya juga dapat diramalkan. Contoh sistem komputer.

Sistem Probabiltas (Probabilistic System), adalah sistem yang tidak bisa diramalakan. Contohnya Sistem Manusia.

d. Closed System \& Open System

Sistem Tertutup (Closed System), adalah sistem yang tidak berhubungan dengan lingkungan luarnya.

Sistem Terbuka (Open System), adalah sistem yang berhubungan atau dipengaruhi oleh lingkungan luarnya.

\section{Peran Sistem Informasi}

Sistem informasi memiliki peran dalam menunjang kegiatan bisnis operasional, menunjang manajemen dalam pengambilan keputusan, dan menunjang keunggulan strategi kompetetif organisasi. Peran sistem informasi untuk mencapai keunggulan strategis dapat dicontohkan pada suatu perusahaan yang memutuskan untuk mengubah seluruh datanya menjadi basis data dengan alat penghubung standar (seperti alat 
penghubung browser web) sehingga memungkinkan berbagi informasi dengan para sekutu-sekutu bisnis dan pelanggannnya. Basis data yang terstandarisasi dan dapat diakses melalui browser web mencerminkan pergeseran posisi perusahaan secara strategis.

Fungsi dari Informasi bagi pemakai :

1. Meningkatkan pengetahuan

2. Mengurangi ketidakpastian dalam proses pengambilan keputusan

3. Mengambarkan keadaan yang real dari sesuatu hal.

Pengelola Sistem Informasi

1. Top Management, perencanaan strategis, kebijakan dan pengambilan keputusan

2. Middle management, perencanaan taktis dan pengambilan keputusan

3. Low management, perencanaan, pengawasan operasi dan pengambilan keputusan

4. Operator, pemrosesan transaksi dan respon permintaan.

\section{E. Sistem Informasi Manajemen (SIM) \& Sistem Informasi} Akuntansi (SIA)

1. Sistem Informasi Manajemen

Menurut Laudon \& Laudon (2008) sistem informasi manajemen adalah sekumpulan komponen 
yang saling berhubungan, mengumpulkan (atau mendapatkan), memproses, menyimpan dan mendistribusikan informasi untuk menunjang pengambilan keputusan dan pengawasan dalam organisasi. Sehingga dapat diartikan Sistem informasi manajemen (SIM) merupakan suatu sistem berbasis komputer yang menyediakan informasi bagi beberapa pemakai dengan kebutuhan yang serupa. Para pemakai biasanya membentuk suatu entitas organisasi formal perusahaan atau sub unit dibawahnya. Sistem ini menggunakan perangkat keras (hardware) dan perangkat lunak (software) komputer, prosedur pedoman, model manajemen dan keputusan, dan sebuah "data base".

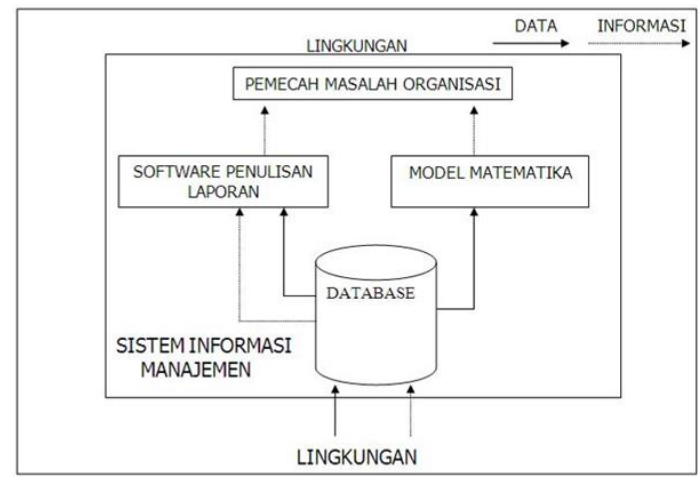

Gambar 1

Siklus Sistem Informasi Manajemen 
Peran sistem informasi manajemen untuk mencapai keunggulan strategis dapat dicontohkan pada suatu perusahaan yang memutuskan untuk mengubah seluruh datanya menjadi basis data dengan alat penghubung standar (seperti alat penghubung browser web) sehingga memungkinkan berbagi informasi dengan para sekutu-sekutu bisnis dan pelanggannnya. Basis data yang terstandarisasi dan dapat diakses melalui browser web mencerminkan pergeseran posisi perusahaan secara strategis. Informasi tersebut dapat menjelaskan keadaan perusahaan atau salah satu sistem utamanya mengenai apa yang telah terjadi di masa lalu, apa yang sedang terjadi sekarang dan apa yang mungkin terjadi di masa depan. Informasi tersebut tersedia dalam bentuk laporan periodik, laporan khusus, dan output dari simulasi matematika. Output informasi digunakan oleh manajer maupun nonmanajer dalam perusahaan saat mereka membuat keputusan untuk memecahkan masalah.

Sistem informasi manajeman digambarkan sebagai sebuah bangunan piramida dimana lapisan dasarnya terdiri dari informasi, penjelasan transaksi, penjelasan status, dan sebagainya. Lapisan berikutnya terdiri dari sumber-sumber informasi dalam mendukung operasi manajemen sehari-hari. Lapisan 
ketiga terdiri dari sumber daya sistem informasi untuk membantu perencanaan taktis dan pengambilan keputusan untuk pengendalian manajemen. Lapisan puncak terdiri dari sumber daya informasi untuk mendukung perencanaan dan perumusan kebijakan oleh tingkat manajemen.

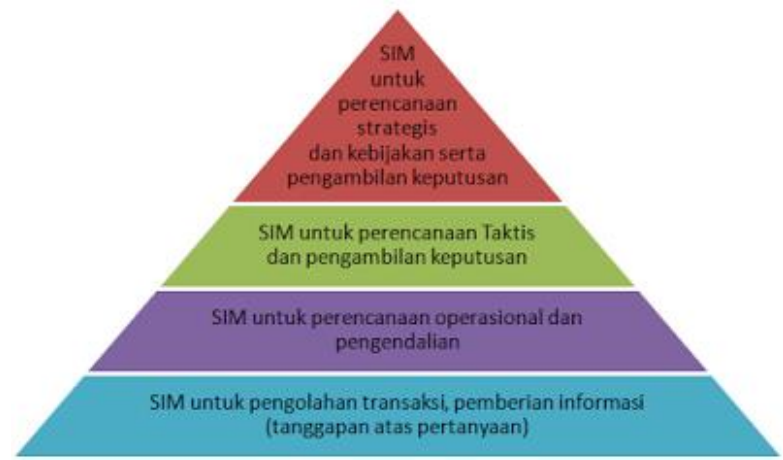

Gambar 2

Piramida Sistem Informasi Manajemen

2. Sistem Informasi Akuntansi

Menurut Azhar (2017) Sistem informasi akuntansi dapat didefinisikan sebagai kumpulan (integrasi) dari sub-sub sistem/ komponen baik fisik maupun nonfisik yang saling berhubungan dan bekerja sama satu sama lain secara harmonis untuk mengolah data transaksi yang berkaitan dengan masalah keuangan menjadi informasi keuangan. Sehingga dapat diartikan bahwa Sistem informasi akuntansi (SIA) adalah suatu 
komponen organisasi yang mengumpulkan, mengklasifikasikan, mengolah, menganalisa dan mengkomunikasikan informasi finansial dan pengambilan keputusan yang relevan bagi pihak luar perusahaan dan pihak ekstern.

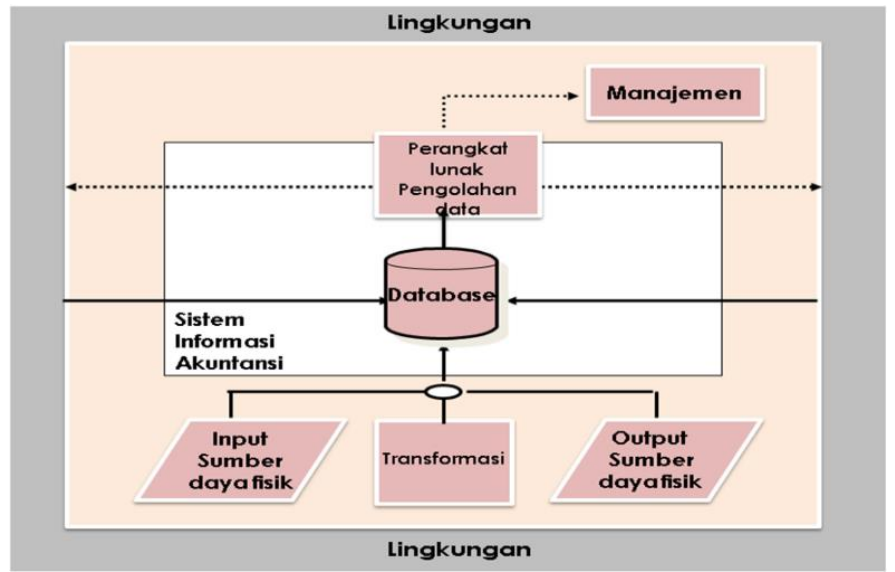

\section{Gambar 3}

Siklus Sistem Informasi Akuntansi

Sistem Informasi Akuntansi memiliki fungsi untuk :

a. Mendukung aktivitas perusahaan sehari-hari

Suatu perusahaan agar dapat tetap eksis perusahaan tersebut harus terus beroperasi dengan melakukan sejumlah aktivitas bisnis yang peristiwanya disebut sebagai transaksi seperti melakukan pembelian, penyimpanan, proses produksi dan penjualan. 
b. Mendukung proses pengambilan keputusan Tujuan yang sama pentingnya dari SIA adalah untuk memberi informasi yang diperlukan dalam proses pengambilan keputusan. Keputusan harus dibuat dalam kaitannya dengan perencanaan dan pengendalian aktivitas perusahaan.

c. Membantu pengelola perusahaan dalam memenuhi tanggung jawabnya kepada pihak eksternal.

Definisi model sistem informasi manajemen dapat digambarkan pada gambar diatas. Database berisi data yang disediakan oleh SIA. Selain itu, data maupun informasi dimasukkan dari lingkungan. Isi database digunakan oleh perangkat lunak yang menghasilkan laporan periodik dan laporan khusus, serta model matematika yang mensimulasikan beragam aspek operasi perusahaan. Output perangkat lunak digunakan oleh orang-orang dalam perusahaan yang bertanggung jawab memecahkan masalah perusahaan. Tidak seperti SIA, SIM tidak berkewajiban menyediakan informasi bagi lingkungan.

\section{Kesimpulan}


Sistem informasi adalah suatu sistem yang menyediakan informasi bagi semua tingkatan dalam organisasi tersebut kapan saja diperlukan. Sistem ini menyimpan, mengambil, mengubah, mengolah dan mengkomunikasikan informasi yang diterima dengan menggunakan sistem informasi atau peralatan sistem lainnya. Sistem informasi memiliki peran dalam menunjang kegiatan bisnis operasional, menunjang manajemen dalam pengambilan keputusan, dan menunjang keunggulan strategi kompetetif organisasi. Ada dua jenis sistem informasi yakni Sistem informasi manajemen (SIM) merupakan suatu sistem berbasis komputer yang menyediakan informasi bagi beberapa pemakai dengan kebutuhan yang serupa. Sedangkan Sistem informasi akuntansi (SIA) merupakan suatu komponen yang berfungsi untuk menginformasikan mengenai keadaan finansial perusahaan sebagai dasar pengambilan keputusan yang relevan dan berguna bagi pihak intern maupun pihak ekstern perusahaan dengan melalui proses mengumpulkan, mengklasifikasikan, mengolah, menganalisa dan mengkomunikasikan informasi finansial yang ada.

\section{SOAL}

1. Apakah yang disebut dengan sistem informasi itu dan berikan beberapa contohnya?

2. Mengapa sistem informasi itu penting bagi perusahaan?

3. Bagaimana membedakan data dengan informasi?

4. Jelaskan yang di maksud dengan siklus informasi. 
5. Benarkah bahwa kebutuhan orang terhadap informasi itu berbeda-beda ? jelaskan!

6. Apa yang di maksud nilai informasi ? Berikan contohnya ?

7. Sebutkan elemen-elemen sistem informasi?

8. Jelaskan makna subsitem dan supersistem dan berikan contohnya?

9. Apa yang dimaksud dengan sistem terbuka, sistem tertutup dan sistem relatif tertutup?

10. Jelaskan perbedaan sistem informasi manajemen dengan sistem informasi akuntansi?

\section{Daftar Pustaka}

Azhar, S. (2017). Sistem Informasi Akuntansi. Bandung: Lingga Jaya.

Laudon, K. C., \& Laudon, J. P. (2008). Sistem Informasi Manajemen. Jakarta: Salemba Empat.

McLeod. (2004). Sistem Informasi Manajemen. Jakarta: PT. Indeks.

O’Brien, J. A., \& George M Marakas. (2016). Analisa Sistem Informasi (1st ed.). Yogyakarta: Andi.

Oetomo, B. S. D. (2002). Perencanaan dan Pembangunan Sistem Informasi. Yogyakarta: Andi. 


\section{BAB 2}

\section{SISTEM MANAJEMEN DATABASE}

\section{Tujuan instruksional}

Dengan membaca bab ini, mahasiswa diharapkan untuk mampu :

6. Memahami definisi sistem manajemen database

7. Menjelaskan manfaat sistem manajemen database

8. Menjelaskan komponen utama sistem manajemen database

9. Menjelaskan keuntungan dan kerugian sistem manajemen database

10. Menjelaskan proses menciptakan database

\section{A. Pendahuluan}

Sistem manajemen basis data (database management system) atau kadang disingkat DBMS, adalah suatu sistem atau perangkat lunak yang dirancang untuk mengelola suatu basis data dan menjalankan operasi terhadap data yang diminta banyak pengguna. Menurut Hapsari (2019) Sistem manajemen basis data (database management system-DBMS) adalah peranti lunak yang memudahkan organisasi untuk memusatkan data, mengelola data secara efisien, dan menyediakan akses data bagi program aplikasi. Contoh tipikal DBMS adalah akuntansi, sumber 
daya manusia, dan sistem pendukung pelanggan, DBMS telah berkembang menjadi bagian standar di bagian pendukung (back office) suatu perusahaan. Contoh DBMS adalah Oracle, SQL server 2000/2003, MS Access, MySQL dan sebagainya. DBMS merupakan perangkat lunak yang dirancang untuk dapat melakukan utilisasi dan mengelola koleksi data dalam jumlah yang besar. DBMS juga dirancang untuk dapat melakukan manipulasi data secara lebih mudah. Sebelum adanya DBMS, data pada umumnya disimpan dalam bentuk flat file, yaitu file teks yang ada pada sistem operasi. Sampai sekarangpun masih ada aplikasi yang menyimpan data dalam bentuk flat secara langsung. Menyimpan data dalam bentuk flat file mempunyai kelebihan dan kekurangan. Penyimpanan dalam bentuk ini akan mempunyai manfaat yang optimal jika ukuran filenya relatif kecil, seperti file o dari flat file, seperti bertambahnya kecepatan dalam pengolahan data. Namun metode ini masih memiliki banyak kelemahan, diantaranya adalah masalah manajemen dan keamanan data yang masih kurang.

\section{B. Manfaat Sistem manajemen basis data}

Penyimpanan data dapat dilakukan dalam beberapa bentuk yakni bentuk flat file, spreadsheet maupun dalam bentuk DBMS. Namun bentuk DBMS lebih memiliki 
banyak manfaat apabila dibandingkan dengan bentuk flat file atau spreadsheet, manfaat DBMS diantaranya:

1. Performa penyimpanan dalam bentuk DBMS cukup besar, sangat jauh berbeda apabila dibandingkan dengan bentuk flat file. Disamping memiliki unjuk kerja yang lebih baik, juga akan didapatkan efisiensi penggunaan media penyimpanan dan memori

2. Dengan menggunakan DBMS Integritas data lebih terjamin sehingga tidak terjadi masalah redudansi seperti yang sering terjadi dalam flat file. Redudansi merupakan kejadian berulangnya kumpulan data yang sama dalam sebuah database yang mengakibatkan pemborosan media penyimpanan.

3. Independensi. Dengan menggunakan DBMS perubahan struktur database dimungkinkan terjadi tanpa harus mengubah aplikasi yang mengaksesnya sehingga pembuatan antarmuka ke dalam data akan lebih mudah.

4. Sentralisasi. Dengan manggunakan DBMS data yang ada akan lebih terpusat dan kekonsistenan data yang diakses secara bersama-sama akan lebih terjami sehungga mempermudah dalam pengelolaan database.

5. Keamanan. DBMS memiliki sistem keamanan yang lebih fleksibel sehingga akan memberikan keluwesan dalam pemberian hak. 


\section{Komponen Utama DBMS :}

Ada 5 komponen utama pada DBMS (T. Connolly \& Begg, 2015), yaitu:

1. Hardware (Perangkat Keras)

DBMS dan aplikasi membutuhkan perangkat keras untuk dapat berjalan. Perangkat kerasnya dapat berupa satu personal computer, satu mainframe, maupun jaringan yang terdiri dari banyak komputer. Perangkat keras yang dibutuhkan bergantung dari permintaan dari organisasi dan DBMS yang digunakan.

2. Software (Perangkat Lunak)

Komponen dari perangkat lunak terdiri dari perangkat lunak DBMS itu sendiri dan program aplikasi, bersama dengan sistem aplikasi, termasuk perangkat lunak jaringan jika DBMS digunakan melalui jaringan.

3. Data

Mungkin komponen yang terpenting pada DBMS, terutama dari sudut pandang pengguna, adalah data. Data berperan sebagai jembatan antara komponen mesin (hardware dan software) dan komponen manusia (prosedur dan manusia). Database berisi baik data, maupun meta data, yaitu data tentang data. Struktur dari database disebut skema.

4. Prosedur 
Prosedur menunjuk pada instruksi dan aturan yang mempengaruhi desain dan penggunaan dari database. Para pengguna sistem dan para staf yang mengatur dokumen prosedur database yang dibutuhkan dan bagaimana cara menggunakan atau menjalankan sistem.

5. Manusia

Orang-orang yang berhubungan dengan sistem antara lain :

a. Database designers

Ada dua tipe dari database designer, yaitu :

- Logical database designer, tugasnya berhubungan dengan mengidentifikasi data, relasi antar data, dan batasan pada data yang akan disimpan di database.

- Physical database designer, bertugas untuk memutuskan bagaimana desain logical database direalisasikan. Hal ini termasuk memetakan desain logical database kepada seperangkat tabel dan batasan integritas, memilih struktur penyimpanan yang spesifik dan metode akses data untuk mencapai performa yang baik, dan mendesain aturan keamanan yang dibutuhkan oleh data.

b. Application developers 
Ketika database diimplementasikan, program aplikasi yang menyediakan fungsi yang dibutuhkan oleh pengguna harus diimplementasikan juga. Ini adalah tanggung jawab dari application developers. Biasanya, application developers bekerja dari spesifikasi yang diproduksi oleh system analyst. Setiap program mengandung kalimat yang meminta DBMS untuk melakukan beberapa operasi pada database. Hal ini termasuk mengambil data, memasukkan, mengubah, dan menghapus data.

c. End-users

Para pengguna dapat diklasifikasikan berdasarkan bagaimana mereka menggunakan sistem, yaitu :

- Pengguna dasar

Pengguna dasar adalah pengguna yang terlatih menggunakan DBMS secara awam. Mereka mengakses database melalui program aplikasi tertulis khusus yang diusahakan untuk membuat operasi sesederhana mungkin. Mereka menggunakan operasi database dengan memasukan perintah sederhana atau memilih pilihan dari menu. Hal ini berarti mereka tidak perlu mendalami topik khusus mengenai database atau DBMS.

- Pengguna berpengalaman 
Pengguna berpengalaman biasanya sudah mengenal struktur dari database dan fasilitas yang ditawarkan oleh DBMS. Pengguna berpengalaman mungkin menggunakan bahasa query yang dengan tingkat tinggi seperti SQL untuk melakukan operasi yang dibutuhkan.

\section{Keuntungan dan Kerugian Sistem Manajemen Database}

Keuntungan DBMS menurut Kadir (2001) adalah :

1. Kepraktisan : Mengginakan media penyimpanan sekunder yang berukuran kecil tetapi padat informasi

2. Kecepatan: Mesin dapat mengambil atau mengubah data jauh lebih cepat dari pada manusia

3. Mengurangi Kejemuan : Dengan menggunakan tangan dalam mengganti informasi cenderung bisa membuat kejemuan, namun dengan DBMS ini bisa mengurangi kejemuan

4. Kekinian : Informasi yang tersedia pada DBMS akan bersifat mutakhir dan akurat setiap saat

Kerugian DBMS menurut Connolly \& Begg (2005) yaitu:

1. Rumit : Karena penetapan fungsi dari DBMS yang baik, menyebabkan DBMS menjadi software yang cukup rumit. Seluruh user harus mengetahui fungsi-fungsi 
yang ada dengan baik, sehingga dapat memperoleh manfaatnya

2. Ukuran : Kerumitan dan banyaknya fungsi yang ada menyebabkan DBMS memerlukan banyak software pendukung yang mengakibatkan penambahan tempat penyimpanan dan memori

3. Biaya DBMS : Biaya dari DBMS bergantung pada lingkungan dan fungsinya

4. Biaya Tambahan Hardware : Keperluan tempat pengimpanan untuk DBMS dan basis data mengharuskan membeli tempat penyimpanan tambahan

5. Biaya Konversi : Biaya DBMS dan tambahan hardware mungkin tidak berarti dibandingkan dengan harga untuk mengubah aplikasi yang ada untuk menjalankan DBMS dan hardware yang baru

6. Penampilan (Performance) : Pada dasarnya DBMS dibuat untuk menyediakan banyak aplikasi, akibatnya mungkin beberapa aplikasi akan berjalan tidak seperti biasanya

7. Dampak yang Tinggi dari Kegagalan : Karena sistem yang terpusat, jika seluruh pengguna dan aplikasi terakses dari DBMS maka kerusakan pada bagian manapun dari sistem akan menyebabkan operasi terhenti. 


\section{E. Proses Menciptakan Database}

1. Menentukan kebutuhan data

a. Pendekatan berorientasi masalah

- Mendefinisikan masalah

- Mendefiniskan keputusan

- Mendefinisikan informasi

- Menentukan pemrosesan yg diperlukan untuk menghasilkan informasi

- Menetapkan data yang diperlukan untuk pemrosesan

b. Pendekatan model perusahaan

- Proses top-down model data perusahaan, dimulai saat perencanaan strategis sumber daya informasi

- Mendokumentasikan model data perusahaan dengan ERD

2. Menjelaskan data dengan menggunakan kamus data (dapat mendefinisikan tiap elemen data dalam sistem)

3. Memasukkan data

a. Model data perusahaan

b. Menciptakan model data perusahaan

c. Mengembangkan database.

\section{Kesimpulan}


Sistem manajemen basis data (database management system) adalah suatu sistem atau perangkat lunak yang dirancang untuk mengelola suatu basis data dan menjalankan operasi terhadap data yang diminta banyak pengguna. DBMS memiliki banyak manfaat yakni ruang penyimpanan cukup besar, integritas data lebih terjamin, independensi, data yang terpusat, dan sistem keamanan yang lebih fleksibel. Namun DBMS juga memiliki kelemahan yakni mahal, menggunakan konfigurasi hardware yang besar, dan pembayaran gaji staff DBA relatif mahal.

\section{SOAL}

1. Jelaskan pengertian dari sistem basis data?

2. Sebutkan 8 operasi dasar dari Database?

3. Sebutkan Komponen dari Sistem Basis Data?

4. Sebutkan contoh dari DBMS?

5. Apa yang di maksud dengan user?

6. Jelaskan pengertian dari DBMS?

7. Apa fungsi dari basis data?

8. Jelaskan fungsi basis data Ketersediaan/ Availability?

9. Apa yang di maksud dengan Bahasa Basis Data (Database Language)?

10. Sebutkan komponen Bahasa database menurut fungsinya?

\section{Daftar Pustaka}


Connolly, T., \& Begg, C. (2015). Database Systems A Practical Approach to Design, Implementation, and Management. Harlow: Pearson Education Limited.

Connolly, T. M., \& Begg, C. E. (2005). Database System : A Practical Approach to Design, Implementation, and Management. United State of America: Education Limited.

Hapsari, R. (2019). Sistem Manajemen Basis Data.

Kadir, A. (2001). Dasar Pemrograman Web Dinamis Menggunakan PHP. Yogyakarta: Andi. 


\section{BAB 3}

\section{ANALISIS DAN PENGEMBANGAN SISTEM INFORMASI}

\section{Tujuan instruksional}

Dengan membaca bab ini, mahasiswa diharapkan untuk mampu :

6. Memahami definisi analisis sistem dan analis sistem

7. Menjelaskan tugas analis sistem

8. Menjelaskan tujuan dan fungsi analisis sistem

9. Menjelaskan langkah-langkah analisa sistem

10. Menjelaskan cara menganalisis Kelemahan Sistem Dan membuat Laporan Hasil Analisis Sistem

\section{A. Pendahuluan}

Perkembangan sistem informasi saat ini telah mengalami pertumbuhan yang sangat pesat. Hal ini mengakibatkan timbulnya persaingan yang semakin ketat pada sektor bisnis dan antar organisasi. Oleh karena itu, diperlukan untuk melakukan analisis dan pengembangan sistem informasi dalam sebuah organisasi dengan mulai memanfaatkan sistem informasi dan teknologi yang ada, memperhatikan kebutuhan jangka panjang dan memastikan penerapan sistem informasi yang terintegrasi dengan baik. 


\section{B. Pengertian Analisis Sistem}

Menurut Jogiyanto (2005) Analisis sistem adalah penguraian dari suatu sistem informasi yang utuh kedalam bagian-bagian komponennya dengan maksud untulk mengidentifikasikan dan mengevaluasi permasalahan-permasalahan, kesempatan-kesempatan, hambatan-hambatan yang terjadi dan kebutuhan yang diharapkan sehingga dapat diusulkan perbaikanperbaikannya. Sementara menurut Mulyani (2016) Analisis sistem merupakan suatu teknik penelitian terhadap sebuah sistem dengan menguraikan komponenkomponen pada sistem tersebut dengan tujuan untuk mempelajari komponen itu sendiri serta keterkaitannya dengan komponen lain yang membentuk sistem sehingga didapat sebuah keputusan atau kesimpulan mengenai sistem tersebut baik itu kelemahan ataupun kelebihan sistem. Jadi Analisis sistem adalah penjabaran dari suatu sistem informasi yang utuh ke dalam berbagai macam bagian komponennya dengan maksud agar kita dapat mengidentifikasi atau mengevaluasi berbagai macam masalah maupun hambatan yang akan timbul pada sistem sehingga nantinya dapat dilakukan penanggulangan, perbaikan atau juga pengembangan. Untuk melakukan kegiatan analisis sistem maka diperlukan seorang analis sistem. Analis sistem merupakan orang atau kelompok 
yang dapat menekuni permasalahan maupun kebutuhan yang diperlukan pada suatu sistem. Analis sistem juga bertanggung jawab atas kegiatan penelitian, perencanaan, pengkoordinasian, dan perekomendasian pemilihan software dan sistem yang sesuai dengan kebutuhan perusahaan atau organisasi bisnis. Seorang analis sistem setidaknya harus memiliki empat keahlian yakni: analisis, teknis, manajerial, dan interpersonal (berkomunikasi dengan orang lain). Dengan kemampuan analisis maka memungkinkan seorang analis untuk memahami bagaimana perilaku organisasi beserta fungsifungsinya, pemahaman tersebut membantu dalam identifikasi kemungkinan terbaik serta membantu menganalisis penyelesaian permasalahan yang ada. Dengan keahlian teknis maka akan membantu seorang analis untuk memahami bagaimana potensi dan keterbatasan dari teknologi informasi. Seorang analis sistem harus mampu untuk memahami berbagai jenis bahasa pemrograman, sistem operasi, serta perangkat keras yang digunakan. Dengan kemampuan manajerial maka akan membantu seorang analis untuk mengelola proyek, sumber daya, risiko, dan perubahan dari teknologi informasi. Dengan kemampuan interpersonal seorang analis maka akan membantu dalam cara berinteraksi yang tepat dengan pengguna. 
Analis sistem juga dapat menjadi perantara antara perusahaan penjual perangkat lunak dengan perusahaan atau organisasi tempat ia bekerja, dan bertanggung jawab atas segala bentuk kegiatannya termasuk analisis biaya pengembangan, usulan desain dan pengembangan, serta menentukan rentang waktu yang diperlukan. Analis sistem juga bertanggung jawab atas studi kelayakan sistem komputer sebelum membuat satu usulan kepada pihak manajemen perusahaan.

\section{Tugas Analis Sistem}

Pada dasarnya seorang analis sistem melakukan halhal berikut:

1. Berinteraksi dengan pelanggan untuk memahami kebutuhan sistem yang akan di gunakan

2. Berinteraksi dengan desainer untuk mengemukakan antarmuka yang diinginkan atas suatu perangkat lunak

3. Berinteraksi ataupun memandu programer dalam proses pengembangan sistem agar tetap berada pada jalurnya

4. Melakukan pengujian sistem baik dengan data sampel atau data sesungguhnya untuk membantu para penguji

5. Mengimplementasikan sistem baru/sistem usulan yang akan digunakan perusahaan

6. Menyiapkan dokumentasi berkualitas 
Menurut (Hanafi \& Halim, 2014) dalam melakukan analisis mengharuskan seorang analis untuk melakukan beberapa hal berikut:

1. Menentukan dengan jelas tujuan dari analisis

2. Memahami konsep-konsep dan prinsip-prinsip yang mendasari laporan keuangan tersebut

3. Memahami kondisi perekonomian dan kondisi bisnis lain pada umumnya yang berkaitan dengan perusahaan dan mempengaruhi usaha perusahaan

\section{Tujuan dan Fungsi Analisis Sistem}

1. Tujuan Analisis Sistem

Tujuan dari analisis sistem informasi adalah untuk merancang sistem baru ataupun menyempurnakan sistem yang sudah ada sebelumnya. Berikut ini, tujuan dari analisis sistem:

a. Mempelajari dan mengidentifikasi sistem yang sedang berjalan saat ini berfungsi dengan baik atau tidak.

b. Membantu dalam membuat keputusan jika sistem yang ada saat ini bermasalah ataupun tidak berfungsi dengan baik.

c. Mengetahui ruang lingkup pekerjaan

2. Fungsi Analisis Sistem

Adapun fungsi dari analisis sistem adalah: 
a. Mengidentifikasikan berbagai masalah dari pemakai .

b. Menentukan sasaran yang harus diperbaiki atau diperbarui untuk dapat memenuhi kebutuhan user.

c. Memecahkan masalah pada sistem dengan memilih metode alternatif yang tepat.

d. Merencanakan dan menerapkan rancangan sistem sesuai dengan apa yang diperlukan dan diinginkan user.

\section{E. Langkah - Langkah Analisa Sistem}

Langkah dalam melakukan analisa sistem hampir sama dengan langkah-langkah yang dilakukan dalam mendefinisikan proyek-proyek sistem yang akan dibesarkan di tahap perencanaan sistem. Namun terdapat perbedaan dalam ruang lingkup tugasnya. Analisa sistem memiliki tugas ruang lingkup yang lebih terinci.

Tahap analisa sistem terdapat langkah-langkah dasar yang harus dilakukan oleh seorang analis sistem, yakni:

1. Identify: mengidentifikasikan masalah

2. Understand: memahami kerja dari sistem yang ada

3. Analyze : menganalisis sistem

4. Report : membuat laporan hasil analisis. 


\section{F. Analisis Kelemahan Sistem Dan Laporan Hasil Analisis Sistem}

1. Menganalisis Kelemahan Sistem

Berikut ini terdapat beberapa menganalisis kelemahan sistem, terdiri atas:

a. Menganalisis Distribusi Pekerjaan

b. Menganalisis Pengukuran Pekerjaan

c. Menganalisis Keandalan

d. Menganalisis Dokumen

e. Menganalisis Laporan

f. Menganalisis Teknologi

2. Berikut ini membuat laporan hasil analisis sistem, terdiri atas:

a. Pelaporan bahwa analisis telah selesai dilakukan

b. Meluruskan kesalah-pengertian mengenai apa yang telah ditemukan dan dianalisis oleh analis sistem tetapi tidak sesuai menurut manajemen

c. Meminta pendapat-pendapat dan saran-saran dari pihak manajemen

d. Meminta persetujuan kepada pihak manajemen untuk melakukan tindakan selanjutnya (dapat berupa meneruskan ke 
tahap desain sistem atau menghentikan proyek bila dipandang tidak layak lagi).

\section{Kesimpulan}

Analisis sistem merupakan penjabaran dari suatu sistem informasi yang utuh menjadi berbagai macam bagian komponen agar dapat dilakukan identifikasi atau evaluasi masalah maupun hambatan yang akan timbul pada sistem sehingga masalah dapat ditanggulangi, diperbaiki ataupun dikembangkan. Diperlukan seorang analis sistem untuk melaksanakan pengembangan sistem, identifikasi permasalah ataupun kebutuhan pada suatu sistem.

Tujuan dari melakukan analisis sistem informasi adalah untuk perancangan sistem baru ataupun penyempurnaan sistem yang telah ada sebelumnya. Untuk melakukan analisis sistem analis perlu mengidentifikasi berbagai macam masalah yang dialami pemakai/user. Analisis sistem berfungsi untuk menentukan sasaran yang perlu diperbarui atau diperbaiki untuk dapat memenuhi kebutuhan user, memilih metode alternatif yang tepat untuk memecahkan masalah pada sistem, dan merencanakan juga menerapkan rancangan sistem sesuai dengan apa yang diperlukan dan diinginkan user.

\section{SOAL}


1. Jelaskan yang pengertian dari sistem?

2. Sebutkan syarat-syarat dari sebuah sistem?

3. Apa yang dimaksud dengan sistem fisik dan sebutkan contohnya?

4. Sebutkan salah satu metode sistem?

5. Sebutkan yang dimaksud dengan sistem abstrak?

6. Sebutkan elemen-elemen RAD (Rapid Application Development)?

7. Apa yang dimaksud dengan analisis masalah?

8. Apa fungsi dari analisis sistem?

9. Jelaskan yang dimaksud dengan deterministik sistem?

10. Apa yang dimaksud dengan analisis dan perancangan sistem?

\section{Daftar Pustaka}

Hanafi, M. M., \& Halim, A. (2014). Analisis Laporan Keuangan. Yogyakarta: UPP AMP YKPN.

Jogiyanto. (2005). Analisis \& Desain Sistem Informasi :

pendekatan terstruktur teori dan praktek aplikasi bisnis. Yogyakarta: Andi.

Mulyani, S. (2016). Metode Analisis dan Perancangan Sistem. Bandung: Abdi Sistematika. 


\section{BAB 4}

\section{SISTEM INFORMASI PEMASARAN}

\section{Tujuan instruksional}

Dengan membaca bab ini, mahasiswa diharapkan untuk mampu :

5. Memahami definisi sistem informasi pemasaran

6. Menjelaskan komponen-komponen dasar sistem informasi pemasaran

7. Menjelaskan peran sistem informasi pemasaran

8. Menjelaskan model-model sistem informasi pemasaran

\section{A. Pendahuluan}

Untuk memahami apa yang dimaksud dengan sistem informasi pemasaran dan mengapa sistem itu sangat membantu bagi suatu organisasi, kita harus terlebih dahulu mengerti apa yang dimaksud dengan pemasaran. Asosiasi Pemasaran Amerika (American Marketing Association / AMA) telah mendefinisikan pemasaran sebagai "suatu proses pelaksanaan konsep, harga, promosi, dan pendistribusian ide, barang dan jasa untuk menciptakan perdagangan yang memuaskan individu dan tujuan-tujuan organisasi" (Kotler \& Keller, 2009). Tindakan-tindakan yang ada digambarkan di dalam definisi ini karena para pelaku pasar lebih menitik 
beratkan pada berbagai aspek dari organisasi perusahaan modern, mulai dari perencanaan, penelitian dan pengembangan hingga pabrikasi, transportasi, pergudangan dan pemantauan inventarisasi, begitu juga dengan program-program promosi dan penjualan. Untuk menjalankan kegiatan-kegiatan ini secara efektif para pemimpin pemasaran membutuhkan informasi yang akurat dan peralatan untuk memproses informasi tersebut.

\section{B. Pengertian Sistem Informasi Pemasaran}

Menurut Azhar (2002) Sistem informasi pemasaran merupakan kumpulan dari sub-sub sistem yang saling berhubungan satu sama lain secara harmonis dengan tujuan untuk mengolah data yang berkaitan dengan masalah pemasaran menjadi informasi pemasaran yang diperlukan oleh manajemen untuk mengambil keputusan dalam rangka melaksanakan fungsinya. Sistem informasi pemasaran (SIP) terdiri dari orang-orang, peralatan, dan prosedur-prosedur untuk mengumpulkan, menyortir, menganalisis, mengevaluasi dan mendistribusikan informasi dengan tepat waktu, akurat, dan dibutuhkan kepada para pembuat keputusan pemasaran (Kotler, 2005). Hal yang perlu ditekankan dalam Sistem Informasi Pemasaran, yakni: 
1. Harus dilihat sebagai sistem yang luas dan fleksibel karena kegiatan-kegiatan pemasaran dari suatu perusahaan saling berhubungan satu sama lain dan harus disesuaikan dengan perubahan lingkungan yang ada. Sebagai contoh, hasil penjualan dipengaruhi oleh ketersediaan produk, kepuasan dari pelanggan, periklanan, dan sebagainya. Dengan begitu, suatu rancangan dari sistem informasi pemasaran yang baik bukan hanya petunjuk penjualan atau laporan triwulan dari peningkatan produk, namun sistem tersebut harus memungkinkan para pihak yang berkepentingan untuk mengambil berbagai informasi yang dibutuhkan untuk mengatasi masalah-masalah pemasaran yang dihadapi.

2. Harus berbentuk formal dan berkelanjutan. Sistem harus dirancang dengan teliti dan sesuai dengan kebutuhan organisasi sehingga sistem tersebut akan memenuhi kebutuhan para pemimpin pemasaran secara berkelanjutan. Untuk mencapai tujuan dari organisasi maka sistem tersebut harus ditentukan sesuai dengan pengetahuan atas pekerjaan para manajer pemasaran, dan perkembangan dari sistem tersebut harus mempunyai komitmen dan dukungan luas dari organisasi. 
3. Harus memberikan susunan informasi yang relevan untuk memandu pembuatan keputusan pemasaran. Dengan ini berarti sistem harus dirancang untuk memberikan berbagai bentuk data yang dapat memandu pembuatan keputusan perusahaan dan memberikan alat-alat yang dibutuhkan untuk menunjang perubahan data ke dalam bentuk informasi yang akan membantu para manajer dalam membuat keputusan manajemen pemasaran yang bijaksana dan terperinci. Sistem juga harus memenuhi kebutuhan dan harapan dari pemakai sistem tersebut.

\section{Komponen - Komponen Dasar Sistem Informasi Pemasaran}

Komponen-komponen dasar dari Sistem Informasi Pemasaran terdiri atas :

1. Lingkungan internal (internal environment)

2. Perangkat pengguna (user interfaces)

3. Basis data (database)

4. Perangkat lunak aplikasi (applications software)

5. Dukungan adminitratif (administrative supports) Komponen dasar sistem informasi pemasaran tersebut dapat diilustrasikan dalam suatu diagram berikut. 


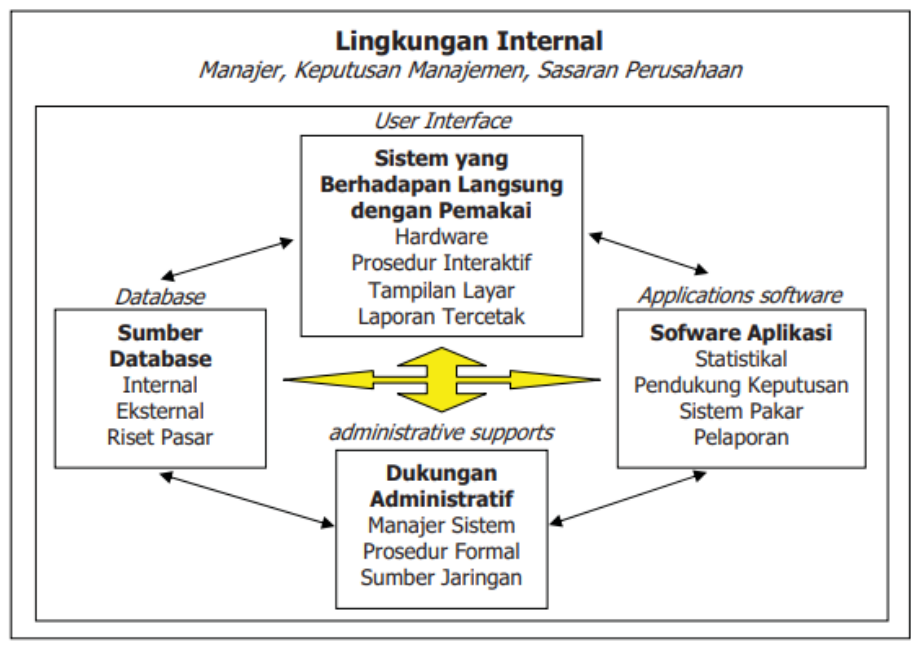

Gambar 1

Komponen Dasar Sistem Informasi Pemasaran

\section{Peran Sistem Informasi Pemasaran}

Dalam mengembangkan Sistem Informasi Pemasaran manajer pemasaran harus benar-benar mengetahui langkah apa yang harus dilakukan dan bagaimana tipe informasi yang diharapkan dapat membantu para manajer untuk mengambil suatu keputusan yang tepat. Tujuannya adalah untuk mengetahui dengan jelas tentang keuntungan dari Sistem Informasi Pemasaran. Pemakaian kata dari pemasaran kadangkala multitafsir. Sebagian orang mengartikan pemasaran sebagai promosi produk yang sederhana sementara sebagian lainnya mengartikan sebagai 
persamaan kata untuk penjualan. Aktivitas penjualan, promosi, pengiklanan, semuanya merupakan bagian dari pemasaran, namun pemasaran mempunyai arti yang dalam dan luas dari semua definisi di atas. Kenyataannya departemen pemasaran dapat dikenal sebagai peluang pertukaran yang meliputi berbagai aktivitas yang tersirat pada definisi dari AMA tentang pemasaran. Yakni menciptakan suatu pertukaran yang memuaskan bagi tujuan perorangan atau individu dari suatu organisasi dengan proses menjalankan konsep dari memberi harga, promosi penjualan, dan distribusi ide, barang dan jasa.

Kunci dari keunggulan kompetitif pemasaran adalah dengan menggunakan Informasi yang ada, namun informasi juga bagaikan pedang bermata dua. Di satu sisi, data yang terlalu banyak dapat mengakibatkan manajer tidak dapat mengatasinya namun dilihat dari sisi lainnya, data yang tidak akurat/kurang lengkap dapat berimplikasi pada kesalahan dalam pengambilan keputusan. Dengan begitu dalam membangun sistem informasi pemasaran harus mampu mengidentifikasi prioritas informasi yang dibutuhkan manajer pemasaran dan top eksekutif yang menggunakan sistem tersebut. Pembuat sistem juga harus mengantisipasi kebutuhan informasi yang akan datang dan mengetahui bagaimana manajer pemasaran dapat menggunakan 
informasi untuk membuat suatu keunggulan kompetitif. Keluasan cakupan dan keberagaman informasi yang diperoleh dari pasar dapat membantu mengembangkan model atau tipe data yang benarbenar dibutuhkan oleh manajer pemasaran.

Keuntungan dari sistem informasi pemasaran adalah :

1. Perusahaan dapat memproses setiap informasi yang ada pada perusahaan tersebut.

2. Memudahkan manajemen waktu.

3. Perusahaan akan lebih sigap dengan kekeliruan data yang ada.

4. Perusahaan dapat mengontrol perkembangan bisnis.

5. Sistem informasi perusahaan akan menghindari kesalah fatal yang disebabkan oleh manusia.

\section{E. Model Sistem Informasi Pemasaran}

Sistem Informasi Pemasaran merupakan sistem informasi manajemen yang menyediakan informasi untuk memecahkan masalah pemasaran perusahaan. Sistem informasi pemasaran ini terdiri dari sub sistem input dan sub sistem output.

1. Sub sistem input Pemasaran

a. Sistem Informasi Akutansi

Pemasaran berperan penting dalam SIA perusahaan dengan menyediakan data pesanan penjualan. Mungkin wiraniaga akan 
memasukkan data dari kantor pelanggan, dengan menggunakan laptop, atau pegawai pesanan penjualan di kantor pusat mungkin mengambil data pesanan melalui telepon atau surat, dan memasukkannya ke dalam terminal keyboard.

Data itu digunakan untuk menyiapkan informasi dalam bentuk laporan periodik dan khusus. Data itu juga menyediakan input bagi model matematika dan sistem pakar.

b. Subsistem Penelitian Pemasaran

Manajer pemasaran dapat menggunakan penelitian pemasaran untuk mengumpulkan segala jenis informasi, tetapi sebagian besar kegiatan ditujukan pada pelanggan dan calon pelanggan. Pemasar menggunakan istilah konsumen untuk menggambarkan kedua kelompok ini.

1) Data primer dan data sekunder

Terdapat dua jenis data yang dikumpulkan yakni primer dan sekunder. Data primer adalah data yang dikumpulkan oleh perusahaan. Contohnya adalah data yang dikumpulkan oleh wiraniaga perusahaan. Sedangkan data 
yang dikumpulkan oleh orang lain disebut data sekunder.

2) Perangkat lunak penelitian pemasaran

Walau perangkat lunak membuat riset pemasaran dapat dilakukan oleh semua ukuran perusahaan, ini bukan merupakan kunci bagi penelitian yang efektif. Kuncinya adalah keahlian yang digunakan untuk merancang proyek penelitian dan menafsirkan penemuannya. Jika keahlian tidak ada dalam perusahaan, keahlian itu dapat berasal dari konsultan, atau perusahaan dapat mendaftarkan para pegawainya pada penelitian pemasaran.

c. Subsistem Inteligen Pemasaran

Subsistem intelijen pemasaran berperan untuk mengumpulkan data pesaing. Pemasaran tidak bertanggung jawab untuk membuat arus keluar bagi pesaing tapi membuat arus masuk.

Jika mendengar kata intelijen pemasaran maka akan dengan mudah kita menghubungkannya dengan memata-matai perusahan lain - spoinase industri (industrial 
espionage). Pekerjaan tersembunyi ini berlangsung dalam dunia bisnis yang kompetitif, tapi sedikit kejadian yang telah dipublikasikan. Perusahaan enggan untuk melaporkan pencurian informasi berharga karena takut merusak citra perusahaannya.

Intelijen pemasaran

(marketing intellegence) mengacu pada berbagai kegiatan yang etis dan dapat digunakan untuk mendapatkan informasi tentang pesaing. Intelijen bisnis digunakan untuk mengetahui bagaimana perusahaan dapat terus mengikuti perkembangan elemen-elemen lingkungannya, dengan menggunakan media elektronik.

2. Sub sistem output Pemasaran

a. Sub sistem produk

Yakni semua perangkat lunak yang menginformasikan manajer mengenai produk. Produk merupakan suatu unsur utama di dalam marketing mix dan perusahaan pun berhak memutuskan untuk menyediakan produk untuk memenuhi kebutuhan pasar tertentu. Tugas dari manager pemasaran adalah mengembangkan suatu strategi dan taktik di dalam marketing mix dan 
mengintegrasikannya menjadi suatu rencana pemasaran. Siklus hidup produk (product life cycle) merupakan penjualan suatu produk yang dimulai dari perkenalan, perkembangan, dan penurunan. Tahap perkenalan tahap dimana untuk memperkenalkan suatu produk. Tahap perkembangan merupakan strategi untuk membuat bagaimana penjualan akan tetap berjalan. Tahap penurunan suatu tahap dimana penghapusan suatu produk yang sudah tidak dikonsumsi lagi oleh konsumen.

b. Sub sistem tempat

Berbagai saluran distribusi yang digunakan perusahaan untuk menyalurkan produknya ke konsumen merupakan unsur tempat dalam bauran pemasaran. Produk atau material, bukan satu-satunya sumber daya yang mengalir melalui saluran tersebut.

c. Sub sistem promosi

Yakni semua perangkat lunak yang memberi informasi manajer tentang penjualan secara langsung atau melalui periklanan. Promosi merupakan salah satu cara untuk meningkatkan tingkat penjualan dalam bidang pemasaran. Satu area promosi tempat komputer yaitu komunikasi wiraniaga. Para 
wiraniaga tersebut membawa komputer portable dan digunakannya untuk mendapatkan informasi untuk menjawab pertanyaan konsumen mengenai produk yang ingin mereka beli, harga produk tersebut, biaya pengiriman.

Memasukkan data pesanan penjualan ke dalam entry pemesanan produk. Sistem memberikan kemudahan bari wiraniaga yaitu informasi mengenai calon pelanggan baru, mengenai produk yang paling mengutungkan bagi perusahaan untuk dijual, dan dapat mengetahui selera para konsumen

d. Subsistem harga

Yakni perangkat lunak yang memberikan informasi pada manajer tentang harga produk. Subsistem harga hampir serupa dengan subsistem promosi dalam hal dukungan keputusan. Penentuan Harga Berdasarkan Biaya menetukan biaya-biaya yang akan dikeluarkan dan menambahkan mark-up yang diinginkan. Penentuan Harga Berdasarkan Permintaan menetapkan harga sesuai dengan nilai yang ditempatkan oleh konsumen terhadap suatu produk.

e. Subsistem bauran terintegrasi 
Manajer dapat menggunakan subsistemsubsistem ini secara terpisah atau gabungan. Integrated mix subsystem (subsistem bauran terintegrasi) memungkinkan manajer mengembangkan strategi pemasaran yang menggunakan campuran unsur-unsur secara gabungan.

Untuk tiap output sistem, manajemen memutuskan bahwa informasi tertentu dapat berguna dalam memecahkan masalah pemasaran. Perangkat lunak dikembangkan untuk menyediakan informasi mengenai unsur-unsur bauran pemasaran melalui berbagai cara atau kombinasi subsistem informasi pemasaran.

\section{Kesimpulan}

Sistem Informasi Pemasaran merupakan suatu rancangan yang menekankan pada fleksibilitas karena kegiatan-kegiatan pemasaran dari suatu perusahaan saling berhubungan satu sama lain dan harus sesuai dengan perubahan lingkungan yang ada, formalitas dan berkelanjutan dengan kata lain, sistem tersebut harus dirancang dengan teliti dengan tujuan organisasi tertentu yang ada sehingga sistem tersebut akan memenuhi kebutuhan para pemimpin pemasaran untuk periode yang lebih panjang, juga harus memberikan suatu 
susunan aliran informasi yang relevan untuk memandu pembuatan keputusan pemasaran.

Sistem informasi pemasaran memberikan keuntungan berupa kemudahan dalam memproses setiap informasi yang ada pada perusahaan tersebut, memudahkan manajemen waktu, perusahaan akan lebih sigap dengan kekeliruan data yang ada, perusahaan dapat mengontrol perkembangan bisnis juga akan menghindari kesalah fatal yang disebabkan oleh manusia.

Sistem Informasi Pemasaran merupakan sistem informasi manajemen yang menyediakan informasi untuk memecahkan masalah pemasaran perusahaan. Sistem informasi pemasaran ini terdiri dari sub sistem input dan sub sistem output.

\section{SOAL}

1. Sistem informasi pemasaran banyak digunakan dalam pengambilan keputusan, jelaskan maksud dari pengertian berikut?

2. Hal-hal apa saja yang harus kita perhatikan pada saat kita akan membangun Sistem Informasi Pemasaran ?

3. Jelaskan hubungan antara Sistem Informasi Pemasaran dengan Marketing Mix?

4. Apa komponen sistem informasi pemasaran modern ?

5. Jelaskan bagaimana manajer pemasaran dapat menggunakan berbagai tipe informasi untuk membuat keunggulan kompetitif ! 
6. Apa yang dilibatkan dalam system intelegensi pemasaran ?

7. Apa yang dimaksud dengan lingkungan makro serta komponennya dan bagaimana mempengaruhi aktivitas perusahaan?

8. Meliputi apa saja lingkungan internal perusahaan dan bagaimana mempengaruhi aktivitas pemasaran ?

9. Sebutkan dan Jelaskan jenis perusahaan riset pemasaran!

10. Jelaskan pentingnya sistem informasi pemasaran dalam perencanaan strategi jangka panjang organisasi?

\section{Daftar Pustaka}

Azhar, S. (2002). Sistem Informasi Manajemen : Konsep dan Pengembangannya. Bandung: Lingga Jaya.

Kotler, \& Keller. (2009). Manajemen Pemasaran. Jakarta: Erlangga.

Kotler, P. (2005). Manajemen Pemasaran. Jakarta:

Prenhalindo. 


\section{BAB 5}

\section{SISTEM INFORMASI SDM}

\section{Tujuan instruksional}

Dengan membaca bab ini, mahasiswa diharapkan untuk mampu :

5. Memahami definisi sistem informasi SDM

6. Menjelaskan fungsi dan tujuan sistem informasi SDM

7. Menjelaskan kegunaan sistem informasi SDM

8. Menjelaskan model sistem informasi SDM

\section{A. Pendahuluan}

Manajemen sumber daya manusia adalah suatu proses menangani berbagai masalah pada ruang lingkup karyawan, pegawai, buruh, manajer dan tenaga kerja lainnya untuk dapat menunjang aktifitas organisasi atau perusahaan demi mencapai tujuan yang telah ditentukan. Bagian atau unit yang biasanya mengurusi sdm adalah departemen sumber daya manusia atau dalam bahasa inggris disebut HRD atau human resource department. Tiap perusahaan memiliki sistem untuk mengumpulkan dan memelihara data yang menjelaskan sumber daya manusia, mengubah data tersebut menjadi 
informasi, dan melaporkan informasi itu kepada pemakai. Sistem ini dinamakan sistem manajemen sumber daya manusia (human resource information system) atau HRIS.

\section{B. Pengertian Sistem Informasi Sumber Daya}

\section{Manusia}

Sumber daya manusia menurut Hasibuan (2002) adalah kemampuan terpadu dari daya pikir dan daya fisik yang dimiliki individu. Perilaku dan sifatnya ditentukan oleh keturunan dan lingkungannya, sedangkan prestasi kerjanya dimotivasi oleh keinginan untuk memenuhi kepuasannya. Sistem Informasi Sumber Daya Manusia (SISDM/HRIS) merupakan sebuah bentuk interseksi/pertemuan antara bidang ilmu manajemen sumber daya manusia (MSDM) dan teknologi informasi. Menurut Jogiyanto (2005) sistem informasi sumber daya manusia adalah sistem informasi untuk mendukung kegiatankegiatan manajer di fungsi sumber daya manusia. Fungsi ini dulunya bernama fungsi department personalia sekarang diubah namanya menjadi fungsi SDM untuk menunjukan bahwa manusia didalam organisasi adalah sumber daya ekonomis yang penting. Sistem ini menggabungkan MSDM sebagai suatu disiplin yang utamanya 
mengaplikasikan bidang teknologi informasi ke dalam aktifitas-aktifitas MSDM seperti dalam hal perencanaan, dan menyusun sistem pemrosesan data dalam serangkaian langkah- langkah yang terstandarisasi dan terangkum dalam aplikasi perencanaan sumber daya perusahaan/enterprise resource planning (ERP).

\section{Fungsi dan Tujuan Sistem Informasi Sumber Daya Manusia}

1. Menurut Rivai (2009) Fungsi sistem informasi sumber daya manusia, yakni:

a. Memeriksa kapabilitas karyawan saat ini untuk mengisi lowongan yang diproyeksikan

b. Menyoroti posisi pemegang jabatan yang akan dipromosikan akan pensiun, atau akan diberhentikan

c. Menggambarkan pekerjaan yang spesifik atau jenis pekerjaan yang mempunyai tingkat perputaran, pemecatan, ketidakhadiran, kinerja, dan masalah yang tinggi, yang melebihi kadar normal

d. Mempelajari komposisi usia, suku, jenis kelamin, pendidikan, dll 
e. Mengantisipasi kebutuhan rekrutmen, seleksi, latihan, dan pengembangan

f. Perencanaan SDM untuk mengantisipasi pergantian dan promosi

g. Laporan kompensasi untuk memperoleh informasi tentang pembayaran pada karyawan

h. Riset SDM untuk melaksanakan penelitian dalam permasalahan, seperti perputaran karyawan dan ketidakhadiran, atau menemukan tempat yang paling produktif guna mencapai calon-calon baru

i. Penilaian kebutuhan pelatihan untuk menganalisis kerja individu dan menentukan karyawan-karyawan mana yang memerlukan pelatihan lebih lanjut.

Fungsi sistem informasi sumber daya manusia memiliki empat kegiatan utama :

a. Perekrutan dan Penerimaan (recruitment and hiring). SDM membantu membawa pegawai baru ke dalam perusahaan dengan memasang iklan lowongan kerja di Koran, dll. SDM selalu mengikuti perkembangan terakhir dalam peraturan pemerintah yang mempengaruhi praktek kepegawaian dan menasehati manajemen untuk 
menentukan kebijakan yang sesuai.

b. Pendidikan dan Pelatihan. Selama periode kepegawaian, SDM dapat mengatur berbagai program pendidikan dan pelatihan yang diperlukan untuk meningkatkan pengetahuan dan keahlian kerja pegawai.

c. Manajemen Data. SDM menyimpan database yang berhubungan dengan pegawai, dan memproses data tersebut untuk memenuhi kebutuhan informasi pemakai

d. Penghentian dan Administrasi Tunjangan. Selama seseorang dipekerjakan oleh perusahaan, mereka menerima paket tunjangan seperti, RS, Asuransi dokter gigi, dan pembagian keuntungan yang semakin sulit administrasinya

2. Tujuan Sistem Informasi SDM

Sistem informasi sumber daya manusia memiliki dua tujuan utama dalam organisasi, yakni :

a. Untuk meningkatkan efisiensi, dengan menggabungkan data karyawan dan aktivitas sumber daya manusia. Aktivitas 
sumber daya manusia lebih efisien dan lebih sedikit pekerjaan tulis menulis dengan tersedianya informasi yang lebih baik dan adanya otomatisasi.

b. Supaya lebih strategis dan berhubungan dengan perencanaan sumber daya manusia. Data yang mudah diakses akan membuat perencanaan sumber daya manusia dan pembuatan keputusan didasarkan pada informasi yang relevan daripada mengandalkan persepsi dan institusi manajerial.

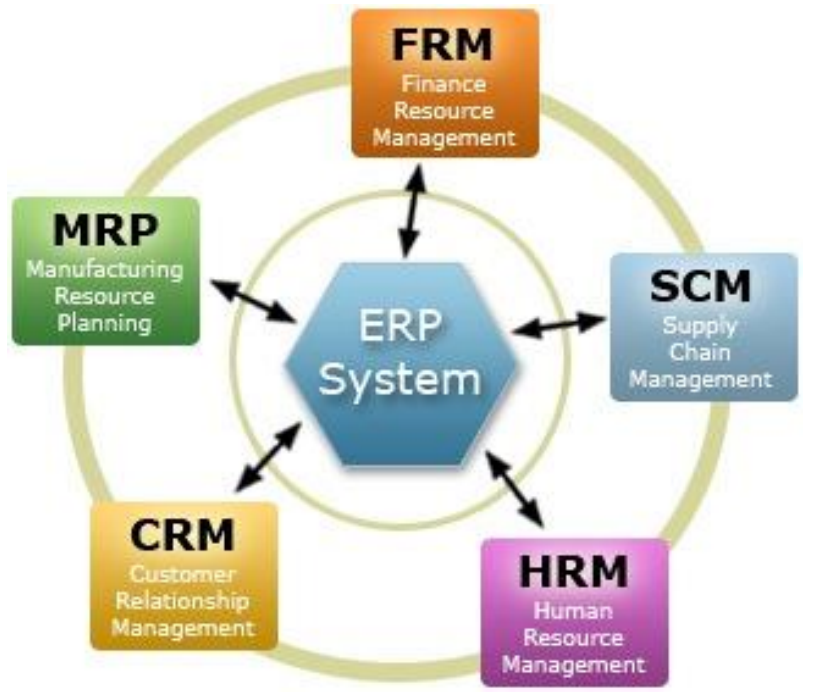

Gambar 1

ERP Sistem

D. Kegunaan Sistem Informasi Sumber Daya Manusia 
Manfaat-manfaat khusus dari system informasi

SDM adalah menilai suplai SDM yang meliputi:

1. Memeriksa kapabilitas karyawan-karyawan saat ini guna mengisi kekosongan yang diproyeksikan di dalam perusahaan.

2. Menyoroti posisi-posisi yang para pemegang jabatannya diperkirakan akan dipromosikan, akan pension atau akan diberhentikan.

3. Menggambarkan pekerjaan-pekerjaan yang spesifik atau kelas-kelas pekerjaan yang mempunyai tingkat perputaran, pemecatat, ketidakhadiran, kinerja, dan masalah yang tinggi yang melebihi kadar normal.

4. Mempelajari komposisi usia, suku, dan jenis kelamin dari berbagai pekerjaan dan kelas pekerjaan guna memastikan apakah semua itu sesuai dengan ketentuan yang berlaku.

5. Mengantisipasi kebutuhan-kebutuhan recruitment, seleksi, pelatihan, dan pengembangan dalam rangka memastikan penempatan yang tepat waktu karyawankaryawan bermutu ke dalam lowongan pekerjaan.

6. Perencanaan sumber daya manusia untuk mengantisipasi pergantian- pergantian dan promosi-promosi. 
7. Laporan-laporan kompensasi untuk memperoleh informasi menyangkut seberapa besar setiap karyawan dibayar, biaya-biaya kompensasi keseluruhan, dan biaya-biaya financial dari setiap karyawan dibayar, biaya-biaya kompensasi keseluruhan, dan biaya-biaya financial dari setiap kenaikan- kenaiakan gaji dan perubahanperubahan kompensasi.

8. Riset sumber daya manusia untuk melaksanakan penelitian dalam permasalahan, seperti perputaran karyawan dan ketidakhadiran, atau menemukan tempat yang paling produktif guna mencapai calon-calon baru.

9. Penilaian kebutuhan pelatihan untuk menganalisis kerja individu dan menentukan karyawan-karyawan mana yang memerlukan pelatihan lebih lanjut.

\section{E. Model Sistem Informasi SDM}

Model SISDM dapat dilihat dari Input - Process Output. Pada sisi input merupakan data mengenai SDM. selain itu, pada sisi process merupakan perangkat keras (hardware), dan perangkat lunak (software), teknologi informasi, serta SDM sebagai operator teknologi komputer tersebut. Selanjutnya pada sisi output merupakan keluaran berupa 
laporan-laporan yang berguna untuk perencanaan SDM. Model input SISDM terdiri atas 3 subsistem yaitu :

1. SIA (Sistem Informasi Akuntansi). SIA menyediakan data akuntansi bagi SISDM sehingga database berisi gambaran yang lengkap dari sumber daya personil baik keuangan maupun non keuangan. Sistem Informasi Akuntansi adalah suatu sistem dalam sebuah organisasi yang bertanggung jawab untuk penyiapan informasi yang diperoleh dari pengumpulan dan pengolahan data transaksi yang berguna bagi semua pemakai baik di dalam maupun di luar perusahaan. Pada subsistem input sistem informasi SDM ini, data yang diolah terdiri dari data personil dan data keuangan.

2. Penelitian Sumber Daya Manusia. Berfungsi untuk mengumpulkan data melalui proyek penelitian khusus. Contoh: Penelitian Suksesi (succession Study), Analisis dan Evaluasi Jabatan (Job Analysis and Evaluation), Penelitian Keluhan (Grievance Studies). Sistem ini bertugas untuk mengumpulkan data dengan melalui kegiatan penelitian khusus seperti : 
a. Penelitian Suksesi. Penelitian mengenai apakah seorang pegawai telah berhasil mencapai kesuksesan dalam bidangnya.

b. Analisis dan Evaluasi Jabatan. Penelitian mengenai apakah seorang pegawai telah melaksanakan tugas dan tanggung jawabnya sesuai dengan jabatan masing-masing.

c. Penelitian Keluhan. Penelitian dengan mengumpulkan data-data berupa keluhan para pegawai tentang keluhan dari pekerjaan mereka agar para pegawai tersebut bisa lebih maksimalkan pekerjaannya dan tidak mengalami kebosanan.

3. Intelijen Sumber Daya Manusia. Berfungsi mengumpulkan data yang berhubungan dengan sumber daya manusia dari lingkungan perusahaan yang meliputi:

- Intelijen Pemerintah. Pemerintah berperan dalam menyediakan data dan informasi yang membantu perusahaan mengikuti berbagai peraturan ketenagakerjaan.

- Intelijen Pemasok. Pemasok mencakup perusahaan asuransi, yang memberikan tunjangan pegawai, lembaga penempatan lulusan universitas serta agen tenaga kerja yang berfungsi sebagai sumber pegawai baru. 
Pemasok ini menyediakan data dan informasi yang dibutuhkan dan memungkinkan perusahaan dalam melaksanakan fungsi perekrutan dan penerimaan.

- Intelijen Serikat Pekerja. Serikat pekerja berperan dalam memberikan data dan informasi yang digunakan dalam mengatur kontrak kerja antara serikat pekerja dan perusahaan.

- Intelijen Masyarakat Global. Masyarakat global berperan dalam menyediakan informasi yang menjelaskan sumber daya lokal seperti perumahan, pendidikan, dan rekreasi. Informasi ini dapat digunakan untuk merekrut pegawai dalam skala lokal, nasional maupun internasional, dan juga untuk mengintegrasikan pegawai yang ada ke dalam komunitas lokalnya.

- Intelijen Masyarakat Keuangan. Masyarakat keuangan berperan dalam menyediakan data dan informasi ekonomi yang digunakan dalam perncanaan personil.

- Intelijen Pesaing. Dalam suatu industri tertentu memerlukan pengetahuan dan keahlian yang sangat khusus, seperti industri komputer, sering terjadi perpindahan 
pegawai dari satu perusahaan ke perusahaan lain. Beberapa perusahaan memandang pesaing mereka sebagai sumber pegawai baru yang baik, dan mengumpulkan informasi mengenai praktek personalia pesaing, dan mungkin informasi perorangan yang berpotensi untuk direkrut.

\section{Kesimpulan}

Sistem Informasi Sumber Daya Manusia (SISDM/HRIS) merupakan sebuah bentuk interseksi/pertemuan antara bidang ilmu manajemen sumber daya manusia (MSDM) dan teknologi informasi. Sistem ini menggabungkan MSDM sebagai suatu disiplin yang utamanya mengaplikasikan bidang teknologi informasi ke dalam aktifitas-aktifitas MSDM seperti dalam hal perencanaan, dan menyusun sistem pemrosesan data dalam serangkaian langkah- langkah yang terstandarisasi dan terangkum dalam aplikasi perencanaan sumber daya perusahaan/enterprise resource planning (ERP).

Fungsi sistem informasi sumber daya manusia memiliki empat kegiatan utama yakni Perekrutan dan Penerimaan (recruitment and hiring), Pendidikan dan Pelatihan, Manajemen Data, dan Penghentian dan Administrasi Tunjangan. 
Tujuan Sistem Informasi SDM, adalah untuk meningkatkan efisiensi, di mana data karyawan dan aktivitas sumber daya manusia digabungkan menjadi satu dan supaya lebih strategis dan berhubungan dengan perencanaan sumber daya manusia.

\section{SOAL}

1. Jelaskan definisi sistem informasi sumber daya manusia!

2. Sebutkan 4 kegiatan utama sistem informasi sumber daya manusia!

3. Sistem informasi sumber daya manusia berbasis jaringan mengolah beberapa data, salah satunya adalah data SDM, sebutkan rincian data-nya !

4. Sistem informasi sumber daya manusia memiliki proses yang dinamis, jelaskan menurut pemahaman anda!

5. Di dalam sebuah sistem kepegawaian terdapat suatu model data yang mencakup proses yang berhubungan dengan perencanaan SDM. Kegiatan apa saja yang dilakukan pada proses ini ?

6. Sistem kepegawaian umumnya memiliki proses administrasi, yang merupakan proses dasar dalam pengumpulan informasi. Keuntungan dari proses ini adalah ?

7. Manajemen yang baik pada proses 
kompensasi/benefit dalam sistem informasi SDM akan memunculkan efek yang positif bagi perusahaan, diantaranya adalah ?

8. Ada 2 jenis kompensasi yaitu kompensasi financial dan non-financial, jelaskan keduanya menurut pemahaman anda!

9. Pada model sistem informasi sumber daya manusia, terdapat teknologi komputer yang dikenal dengan Database, jelaskan tugas dari database!

10. Model sistem informasi sumber daya manusia memiliki 3 sub sistem, sebutkan dan jelaskan!

\section{Daftar Pustaka}

Hasibuan, M. S. P. (2002). Manajemen Sumber Daya Manusia. Jakarta: PT. Bumi Perkasa.

Jogiyanto. (2005). Analisis \& Desain Sistem Informasi : pendekatan terstruktur teori dan praktek aplikasi bisnis. Yogyakarta: Andi.

Rivai, V. (2009). Manajemen Sumber Daya Manusia Untuk Perusahaan Dari Teori ke Praktik. Jakarta: Raja Grafindo Persada. 


\section{BAB 6}

\section{SISTEM INFORMASI MANUFAKTUR}

\section{Tujuan instruksional}

Dengan membaca bab ini, mahasiswa diharapkan untuk mampu :

5. Memahami definisi sistem informasi manufaktur

6. Menjelaskan manfaat sistem informasi manufaktur

7. Menjelaskan model sistem informasi manufaktur

8. Menjelaskan komputer sebagai sistem informasi

\section{A. Pendahuluan}

Perusahaan manufaktur memerlukan informasi untuk melangsungkan roda industrinya. Tanpa informasi yang akurat, perusahaan tidak dapat menentukan kebijakan, keputusan, bahkan peraturan yang dapat menunjang perbaikan maupun perkembangan perusahaan. Oleh karena itu, perusahaan perlu memiliki sebuah sistem informasi yang dikhususkan pada setiap departemen. Hal ini diperlukan untuk membentuk proses bisnis yang lebih menguntungkan bagi perusahaan. 


\section{B. Pengertian Sistem Infomasi Manufaktur}

Menurut Jay \& Barry (2005) manufaktur berasal dari kata manufacture yang berarti membuat dengan tangan (manual) atau dengan mesin sehingga menghasilkan sesuatu barang. Sistem Informasi Manufaktur adalah suatu sistem berbasis komputer yang bekerja dalam hubungannya dengan sistem informasi fungsional lainnya untuk mendukung manajemen perusahaan dalam pemecahan masalah yang berhubungan dengan manufaktur produk perusahaan yang pada dasarnya tetap bertumpu pada input, proses dan output. Menurut Wignjosoebroto (2006) Sistem manufaktur mempunyai definisi sebagai keseluruhan entitas yang bekerja dalam suatu aturan tertentu untuk mengubah resource (material, modal, tenaga, energi dan keterampilan) menjadi produk (barang atau jasa) yang dapat dijual oleh perusahaan dengan melakukan proses produksi tertentu untuk meningkatkan added value suatu resource.

Sistem ini digunakan untuk mendukung fungsi produksi yang meliputi seluruh kegiatan yang terkait dengan perencanaan dan pengendalian proses untuk memproduksi barang atau jasa. Ruang lingkup sistem informasi manufaktur meliputi Sistem 
perencanaan manufaktur, Rencana produksi, Rencana tenaga kerja, Rencana kebutuhan bahan baku dan Sistem pengendalian manufaktur. Sistem Informasi Manufaktur adalah solusi tepat bagi perusahaan yang memikirkan prospeknya dalam jangka panjang. Hal ini dikarenakan sistem informasi manufaktur lebih menekankan kepada proses produksi yang terjadi dalam sebuah lantai produksi, mulai dari input bahan mentah hingga output barang jadi, dengan mempertimbangkan semua proses yang terjadi.

Sistem informasi manufaktur tidak dapat dipisahkan dengan komputer, karena dalam sistem ini komputer memegang andil yang sangat besar, baik secara fisik maupun informatif. Secara fisik, komputer digunakan untuk menjalankan proses produksi dan mengontrol arus produksi tersebut. Sedangkan secara informatif komputer digunakan manajemen manufaktur untuk memperoleh informasi yang akurat dan berguna bagi perusahaan untuk menunjang hasil produksi perusahaan agar lebih maksimal. Namun bukan berarti sistem ini meniadakan secara penuh andil tenaga manusia di dalam suatu perusahaan. Karena antara software, hardware, dan brainware akan selalu berkaitan di setiap sistem yang ada. Tanpa adanya satu dari tiga 
bagian tersebut, maka suatu sistem tidak akan bisa berjalan.

\section{Manfaat Sistem Informasi Manufaktur}

Sistem informasi manufaktur memberikan manfaat bagi perusahaan sebagai berikut :

1. Hasil dari produksi perusahaan lebih cepat dan tepat waktu karena menggunakan komputer sebagai alat prosesnya.

2. Perolehan informasi yang akurat dan terpercaya akan lebih cepat.

3. Kegiatan arsip akan lebih terstruktur karena menggunakan sistem database.

4. Sistem informasi manufaktur yang berupa fisik robotik akan membuat kegiatan produksi semakin cepat, tepat dan mengurangi jumlah sisa bahan yang tidak terpakai.

\section{Model Sistem Informasi Manufaktur}

Terdapat dua jenis input data yakni berupa data internal dan data eksternal. Data internal merupakan keseluruhan data yang berasal dari dalam perusahaan yang mendukung proses pengolahan data menjadi suatu informasi yang bermanfaat bagi perusahaan. Data intern meliputi sumber daya manusia (SDM), material, mesin, dan 
lainnya yang mendukung secara keseluruhan seperti transportasi, spesifikasi kualitas material, frekuensi perawatan, dan lain-lain.

Data eksternal merupakan data yang berasal dari luar perusahaan (environment) yang dapat mendukung proses pengolahan data menjadi informasi yang digunakan untuk perhitungan cost mulai dari awal hingga akhir proses. Contoh dari data eksternal adalah data pemasok (supplier), kebijakan pemerintah tentang UMR, listrik, dll.

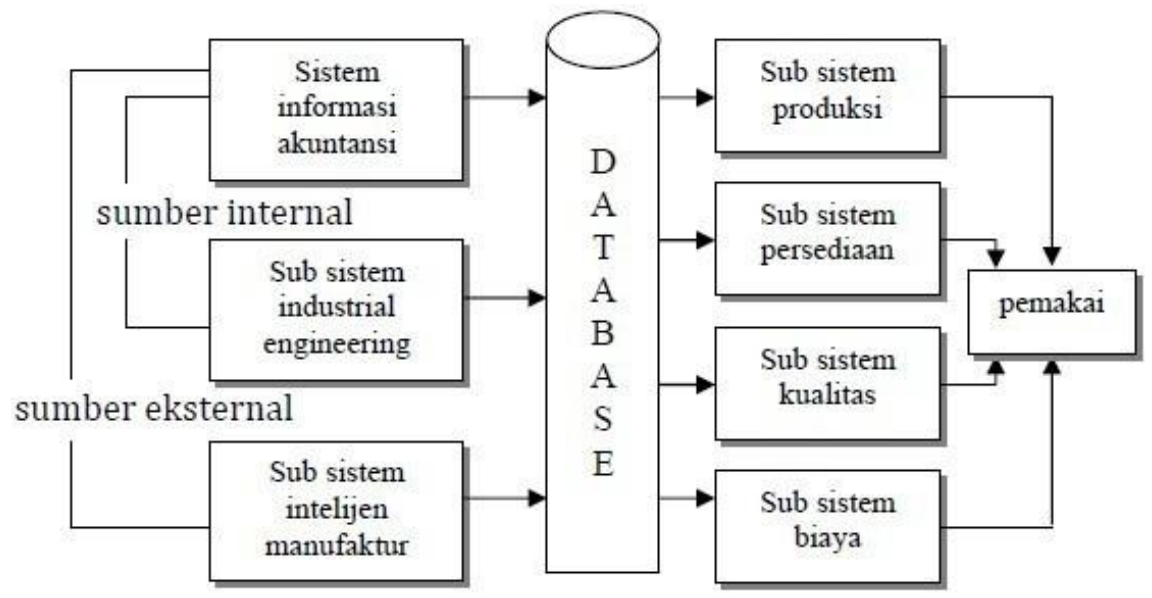

Gambar 1

Sistem Informasi Manufaktur

1. Sub Sistem Input

Sub sistem input terdiri dari :

a. Sistem informasi akuntansi 
Sistem informasi akuntansi mengumpulkan data intern yang menjelaskan proses operasi manufaktur dan data lingkungan yang menjelaskan transaksi antara perusahaan dengan pemasok. Misalnya pegawai produksi memasukan data ke terminal dengan menggunakan kombinasi media berbentuk dokumen dengan barcode yang dapat dibaca secara optik dan kartu plastik dengan garisgaris catatan yang dapat dibaca secara magnetis. Setelah data dibaca kemudian ditransmisikan kekomputer pusat untuk memperbarui database.

b. Sub sistem industrial engineering (IE) Industrial Engineering merupakan kegiatan analisis sistem yang terlatih khusus dengan mempelajari operasi manufaktur dan membuat saran-saran perbaikan. Industrial engineering terdiri dari proyek-proyek pengumpulan data khusus yang berasal dari dalam perusahaan yang menetapkan berapa lama waktu yang dibutuhkan untuk suatu produksi.

c. Sub sistem intelijen manufaktur

Sub sistem intelijen manufaktur berfungsi agar manajemen tetap mengetahui 
bagaimana perkembangan terakhir mengenai sumber-sumber pekerja, material dan mesin. Yang termasuk dalam sub sistem intelijen manufaktur adalah :

- Informasi pekerja. Yang harus diperhatikan adalah serikat pekerja yang mengorganisasikan para pekerja perusahaan, baik dalam sistem kontrak, tak berjangka maupun borongan.

- Sistem formal. Memulai arus informasi pekerja dimulai dengan menyiapkan permintaan pekerja yang dikirimkan ke departemen sumber daya manusia dan keperluan data dari berbagai elemen lingkungan yang menghubungkan kepada pihak pelamar.

- Sistem informal. Berupa kontak harian antara pekerja dengan manajer mereka. Intelijen manufaktur melakukan kegiatan sebagai berikut :

- Pengumpulan atau pendokumentasian data dari lingkungan,

- Melakukan pengujian data,

- Pemeliharaan data, agar terjamin akurasi dan kemutakhiran data.

- Keamanan data, agar terhindar dari 
kerusakan serta penyalahgunaan data.

- Pengambilan data dalam bentuk laporan, agar lebih mudah dalam pengolahan data yang lain.

\section{Sub Sistem Output}

Merupakan informasi yang dihasilkan dari hasil pengolahan data dari 3 bagian yaitu produksi, persediaan dan kualitas, dimana ketiganya ini tidak meninggalkan unsur biaya yang terjadi di dalamnya.

a. Sub sistem produksi

Merupakan proses yang terjadi disetiap divisi kerja ataupun departemen untuk mengukur waktu, menelusuri arus kerja dari satu langkah ke langkah berikutnya dalam kegiatan produksi.

b. Sub sistem persediaan

Sub sistem persediaan menyediakan informasi jumlah stok, biaya holding, safety stock, dan lain-lain berdasarkan hasil dari pengolahan data, biasanya memiliki proses pembelian (purchasing) dan penyimpanan (inventory). Fungsi dari sub sistem persediaan adalah untuk mengukur volume aktifitas produksi saat proses persediaan diubah dari bahan mentah menjadi bahan jadi. 
c. Sub sistem kualitas

merupakan segala hal yang berkaitan dengan kualitas, baik waktu, biaya, performa kerja, maupun pemilihan supplier. Sub sistem kualitas berfungsi untuk mengukur kualitas material saat perubahan material. Banyak hal lain yang bukan unsur mutlak kualitas namun perlu masuk dalam unsur kualitas seperti proses (Process Control), Perawatan (Maintenance), dan Spesifikasi (Specification) baik produk jadi maupun material. Sub sistem kualitas memiliki pendekatan khusus untuk meningkatkan kualitas produksinya dengan menggunakan total quality management (TQM) sehingga perusahaan lebih unggul dalam semua dimensi produk dan jasa yang penting bagi pelanggan. Keyakinan dasar yang melandasi TQM adalah :

- Kualitas ditentukan oleh pelanggan dan penggunaan manajemen

- Kualitas dicapai oleh manajemen

- Kualitas dari tanggung jawab seluruh penghuni perusahaan

d. Sub sistem biaya

Sub sistem biaya termasuk dalam semua komponen biaya yang ada. Tujuan 
perusahaan manufaktur secara umum adalah mendapat keuntungan dari hasil penjualan produknya. Oleh sebab itu, sistem informasi tidak akan pernah terlepas dari unsur biaya yang terjadi di dalamnya. Sub sistem biaya berfungsi untuk mengukur keseluruhan biaya yang terjadi selama proses produksi. Unsur dari pengendalian biaya ada dua yaitu standar kerja yang baik dan sistem untuk melaporkan rincian kegiatan saat terjadinya proses produksi yang akurat. Sub sistem biaya dibagi menjadi dua yaitu :

- Biaya Pemeliharaan

Biaya pemeliharaan / biaya penyimpanan biasanya berbentuk persentase biaya tahunan dari barang, mencakup kerusakan, pencurian, keusangan, pajak dan asuransi.

- Biaya Pembelian

Mencakup biaya-biaya yang terjadi pada saat material dipesan, waktu pembelian, biaya telepon, biaya sekretaris, biaya formulir pesanan pembelian dan lain-lain. 


\section{E. Komputer Sebagai Sistem Informasi}

a. Sistem Pemesanan Kembali ( Re-Order Point/ROP)

Setelah komputer pertama diterapkan dan berhasil dalam area akuntansi, komputer diberikan tugas mengendalikan persediaan. Pendekatan reaktif yang sederhana yaitu menunggu hingga saldo suatu jenis barang mencapai tingkat tertentu dan kemudian memicu pesanan pembelian atau suatu proses produksi. Tingkat barang yang berfungsi sebagai pemicu disebut titik pemesanan barang dan sistem yang mendasarkan keputusan pembelian pada titik pemesanan kembali disebut sistem titik pemesanan kembali (re-order point/ROP). Beberapa istilah dalam ROP antara lain :

- Stock-out : kehabisan persediaan

- Lead time : waktu yang dibutuhkan pemasok untuk mengisi pesanan

- Safety stock: persediaan aman Rumus menghitung ROP :

$$
\mathrm{R}=\mathrm{LU}+\mathrm{S}
$$

$\mathrm{R}=$ titik pemesanan kembali

$\mathrm{L}=$ lead time pemasok 
$U$ = tingkat pemakaian (jumlah unit yang digunakan atau terjual setiap hari) $\mathrm{S}=$ tingkat safety stok (dalam unit)

b. Material Requirement Planing (MRP) MRP dikembangkan pada tahun 1960-an oleh Joseph Orlicky dari J.I case company. MRP adalah suatu strategi material proaktif yaitu mengidentifikasikan material, jumlah dan tanggal yang dibutuhkan. MRP mempunyai 4 komponen meliputi :

- Sistem penjadwalan produksi menghasilkan master jadwal produksi yang mencakup lead time terpanjang ditambah waktu produksi terpanjang.

- Sistem MRP menguraikan tagihan material. Mengubah kebutuhan bruto menjadi kebutuhan netto.

- Sistem perencanaan kebutuhan kapasitas bekerja dengan sistem MRP untuk menjaga produksi dalam kapasitas pabrik. Menghasilkan output, melaporkan dan merencanakan jadwal pemesanan.

- Sistem pelepasan pesanan menghasilkan laporan untuk lantai kerja dan pembelian 


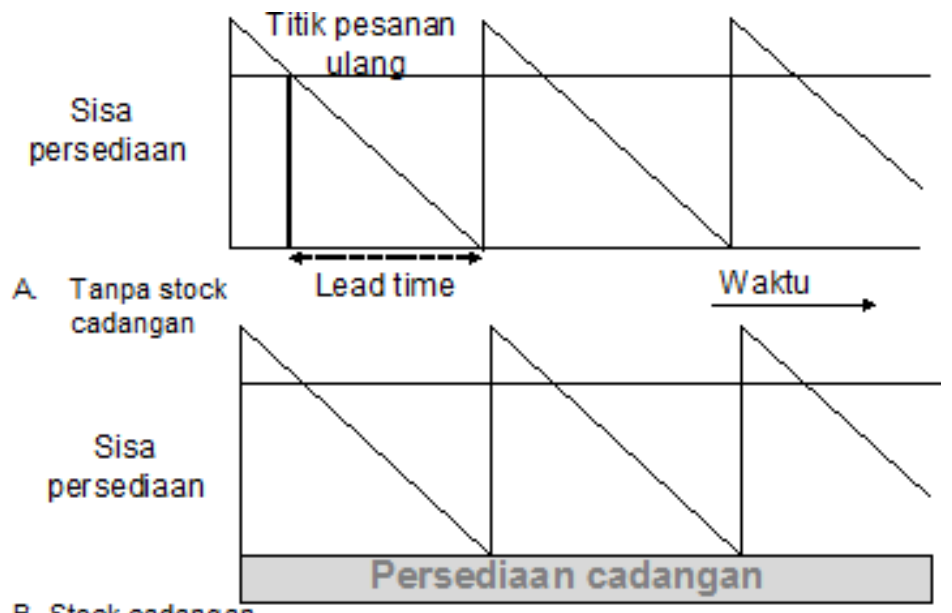

B. Stock cadangan

Gambar

Pemesanan Kembali tanpa cadangan dan

dengan Cadangan

Manfaat MRP bagi perusahaan :

- Perusahaan dalam mengelola materialnya secara lebih efisien

- Perusahaan dapat menghindari kehabisan persediaan barang

- Perusahaan mengetahui kebutuhan material di masa depan

- Pembeli dapat merundingkan perjanjian pembeli dengan pemasok. 
c. Manufacturing Resource Planning (MRP II)

MRP II mengintegrasikan semua proses di dalam manufaktur yang berhubungan dengan manajemen material. MRP II dikembangkan oleh Oliver Wight dan George Plossy.

Manfaat MRP II :

- Penggunaan sumber daya yang lebih efisien; mengurangi inventori, lebih sedikit waktu, lebih sedikit kemacetan.

- Perencanaan prioritas lebih baik; memulai produksi lebih cepat dan jadwal lebih fleksibel.

- Meningkatkan pelayanan pelanggan; sesuai tanggal pengiriman, meningkatkan kualitas, kemungkinan harga lebih rendah/murah.

- Meningkatkan moral dan semangat pekerja

- Informasi manajemen yang lebih baik

d. Pendekatan Just in Time (JIT)

Pada pertengahan tahun 1980-an para manajer Amerika Serikat mempelajari manajemen Jepang dan teknik organisasi untuk mendapatkan kunci keberhasilan penjualan mereka. Salah satu teknik tersebut adalah just in time (JIT). JIT menjaga arus bahan ke pabrik agar sampai yang terendah dengan cara menjadwalnya agar saat tiba di 
workstation (stasiun kerja) "just in time" (tepat waktu). JIT berusaha untuk meminimalkan biaya inventarisasi dengan cara memproduksi dalam jumlah yang lebih kecil. Lot size (ukuran tumpukan) yang ideal akan menjadi satu dalam sistem JIT. Satu unit akan bergerak dari workstation ke workstation berikutnya sampai produksinya selesai.

Pengaturan waktu menjadi kunci Penting saat Pasokan bahan mentah datang dari pemasok sebelum penjadwalan produksi mulai, tidak ada inventarisasi bahan mentah yang perlu dibicarakan. Jumlah bahan mentah yang sedikit diterima sekaligus, karena mungkin pemasok melakukan beberapa kali pengiriman selama satu hari. Kebalikannya dengan MRP yang menekankan perencanaan jangka panjang dan membutuhkan penggunaan komputer, maka JIT menekankan pengaturan waktu dan penggunaan tanda non komputer karena cukup menggunakan "kanban" yang berarti kartu. Tujuan JIT adalah meminimalkan biaya persediaan dan penanganan (keamanan dan asuransi).

\section{Kesimpulan}

Sistem Informasi Manufaktur adalah suatu sistem berbasis komputer yang bekerja dalam hubungannya 
dengan sistem informasi fungsional lainnya untuk mendukung manajemen perusahaan dalam pemecahan masalah yang berhubungan dengan manufaktur produk perusahaan yang pada dasarnya tetap bertumpu pada input, proses dan output. Sistem ini digunakan untuk mendukung fungsi produksi yang meliputi seluruh kegiatan yang terkait dengan perencanaan dan pengendalian proses untuk memproduksi barang atau jasa. Ruang lingkup sistem informasi manufaktur meliputi Sistem perencanaan manufaktur, Rencana produksi, Rencana tenaga kerja, Rencana kebutuhan bahan baku dan Sistem pengendalian manufaktur.

Manfaat digunakannya sistem informasi manufaktur di dalam perusahaan adalah mempercepat hasil produksi perusahaan, Perusahaan lebih cepat memperoleh informasi yang akurat dan terpercaya, Arsip lebih terstruktur, berkurangnya jumlah sisa bahan yang tidak terpakai. Terdapat 2 model sistem informasi manufaktur yakni yang berasal dari sumber internal dan sumber eksternal.

\section{SOAL}

1. Jelaskan pengertian sistem informasi manufaktur!

2. Jelaskan konsep dasar manufaktur dan design sistem manufaktur! 
3. Uraikan pemanfaatan dari CAM, CAD, CIM, ROP, MRP, JIT!

4. Sebutkan manfaat dari sistem informasi manufaktur!

5. jelaskan secara singkat bagaimana gambaran dan contoh dari sistem manufaktur!

6. sebutkan kegiatan apa saja yang terjadi dalam intelijen manufaktur?

7. apakah ada hubungan sistem informasi manufaktur dan sistem informasi keuangan?

8. Jelaskan manfaat komputer sebagai sistem informasi!

9. Jelaskan perbedaan MRP, MRP II dengan JIT !

10. Jelaskan tujuan JIT!

\section{Daftar Pustaka}

Jay, H., \& Barry, R. (2005). Operations Management. Jakarta: Salemba Empat.

Wignjosoebroto, S. (2006). Pengantar Teknik dan Manajemen Industri. Surabaya: Guna Widya. 


\section{BAB 7}

\section{SISTEM INFORMASI KEUANGAN}

Tujuan instruksional

Dengan membaca bab ini, mahasiswa diharapkan untuk mampu :

5. Memahami definisi sistem informasi keuangan

6. Menjelaskan model sistem informasi keuangan

7. Menjelaskan sifat dan bentuk sistem informasi keuangan

8. Menjelaskan fungsi, tujuan dan ruang lingkup sistem informasi keuangan

A. Pendahuluan

Seiring dengan berkembang teknologi informasi di era modern ini, mengakibatkan segala seuatu yang memungkinkan diatur secara teknologi diusahakan secara maksimal atu secara besarbesaran, dimana sistem kerja secara manual perlahan-lahan mulai tergeser dengan adanya teknologi yang semakin canggih. Pemanfaatan Teknologi Informasi merupakan salah satu cara dalam menyelesaikan masalah-masalah yang dihadapi dalam pelaporan keuangan. Dengan adanya sistem yang mempergunakan teknologi 
informasi, pekerjaan penyusunan laporan keuangan akan lebih mudah dan rapi.

\section{B. Pengertian Sistem Informasi Keuangan}

Sistem Informasi Keuangan adalah sistem informasi yang memberikan informasi kepada orang atau kelompok baik di dalam perusahaan maupun di luar perusahaan mengenai masalah keuangan \& menyediakan informasi mengenai arus uang bagi para pemakai diseluruh perusahaan. Sistem informasi manajemen keuangan atau sistem informasi keuangan mengumpulkan dan mengolah semua data keuangan menjadi sebuah informasi yang dibutuhkan oleh pihak yang berkepentingan sebagai dasar pengambilan keputusan keuangan.

Sistem informasi keuangan merupakan bagian dari sistem informasi manajemen (SIM) yang merupakan gabungan atau kumpulan dari beberapa subsistem-subsistem keuangan yang saling terkait dan terhubung dalam jaringan yang sama untuk menghasilkan informasi keuangan perusahaan. Sistem informasi keuangan sering dibutuhkan dalam menghadapi dan memecahkan masalah yang muncul dalam perusahaan, terutama masalah keuangan. Informasi keuangan perusahaan yang dihasilkan harus berkualitas agar informasi tersebut bisa 
memiliki manfaat yang maksimal yang bisa diandalkan sebagai dasar pengambilan keputusan. Sehingga dengan adanya sistem informasi keuangan dapat mempermudah dan memenuhi kebutuhan manajer ataupun berbagai elemen dilingkungan perusahaan atas informasi yang menjelaskan status keuangan perusahaan.

\section{Model Sistem Informasi Keuangan}

Digunakan untuk menjelaskan subsistem CBIS yang memberikan informasi kepada orang / kelompok baik di dalam maupun di luar perusahaan mengenai masalah keuangan perusahaan, informasi disajikan dalam bentuk laporan periodik, laporan khusus, hasil dari simulasi matematika, komunikasi elektronik dan saran dari sistem pakar. Model sistem informasi keuangan yaitu subsistem input dan subsistem output. Model yang dikemukakan tersebut diharapkan menjadi sistem pendukung keputusan bidang keuangan, sehingga dalam anggaran perusahaan alokasi biaya akan tepat sasaran dan proses pengendalian akan lebih mudah dilakukan (Rochaety, Setyowati, \& Ridwan, 2011). 


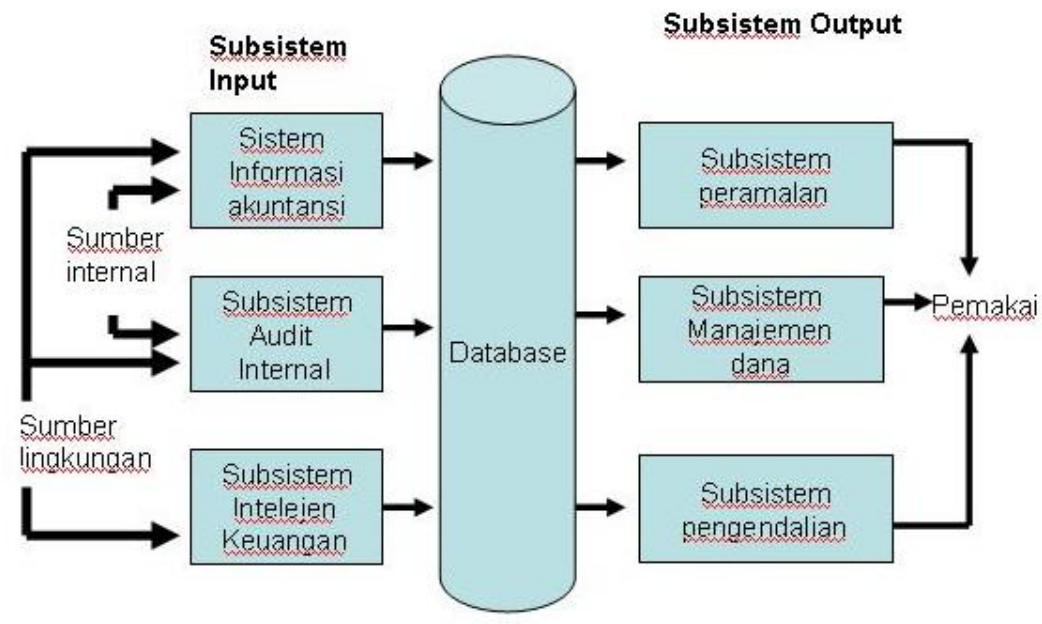

Gambar 1

Model Sistem Informasi Keuangan

1. Sub Sistem Input

a. Sistem Informasi Akuntansi

Data akuntansi yang menyediakan catatan mengenai segala hal yang berhubungan dengan keuangan dalam perusahaan. Catatan ini dibuat untuk segala transaksi yang menjelaskan apa yang terjadi, kapan terjadinya, siapa saja yang terlibat dan berapa banyak uang yang digunakan.

b. Sub Sistem Audit Internal

Audit internal sebagai subsistem dari sistem informasi keuangan karena 
kemampuannya dalam mengevaluasi dan mempengaruhi operasi perusahaan secara independen dari sudut pandang perusahaan.

Jenis dari kegiatan audit :

- Audit keuangan, dilakukan oleh auditor eksternal untuk menguji akurasi catatan perusahaan

- Audit operasional, untuk memeriksa efektifitas prosedur perusahaan

- Audit kesesuaian, sama seperti audit operasional namun audit berlanjut terus

c. Sub Sistem Intelijen Keuangan

Perusahaan mengidentifikasi sumbersumber modal tambahan terbaik dan investasi terbaik bagi dana yang lebih. Untuk mencapai tujuannya, subsistem informasi keuangan mengumpulkan data dan informasi dari pemegang saham, masyarakat keuangan dan pemerintah.

2. Sub Sistem Output

a. Sub Sistem Peramalan

Peramalan merupakan salah satu kegiatan matematis tertua dalam bisnis. Komputer memungkinkan peramal dalam membuat perhitungan secara lebih cepat dan mudah. 
Peramalan jangka pendek dilakukan oleh area-area fungsional. Fungsi pemasaran memproyeksikan penjualan untuk masa depan yang singkat biasanya 1-3 tahun kedepan. Peramalan jangka panjang biasanya dilakukan oleh area selain pemasaran yakni oleh fungsi finansial atau suatu kelompok yang hanya mempunyai tanggung jawab perencanaan.

Metode peramalan :

- Metode nonkuantitatif, perhitungan data tidak dilibatkan namun didasarkan pada penaksiran subyektif.

- Metode kuantitatif, analisis regresi melibatkan pembuatan suatu hubungan antara kegiatan yang akan diramal disebut variabel terikat/dependent variable dengan kegiatan yang lain disebut variabel bebas (independent variable).

b. Sub Sistem Manajemen Data

Pentingnya arus uang dari lingkungan melalui perusahaan dan kembali ke lingkungan, karena uang tersebut digunakan untuk memperoleh sumber daya fisik lain. Arus ini dikelola untuk mencapai tujuan 
memastikan bahwa arus keluar biaya tidak lebih besar dari arus masuk pendapatan, dan untuk memastikan bahwa keadaan ini akan tetap stabil setiap tahun.

c. Sub Sistem Pengendalian

Suatu anggaran operasi yang diberikan kepada manajemen yang digunakan dalam memenuhi tujuan operasional. Proses penganggaran (budgeting process) berisi sejumlah mengenai keputusan semi terstruktur. Data pendukung yang diperlukan biasanya tersedia dalam bentuk catatan akuntansi histories, tapi banyak penilaian yang harus diterapkan.

Pendekatan umum yang dapat diambil perusahaan dalam menentukan anggaranya yaitu :

- Pendekatan dari atas ke bawah, eksekutif perusahaan menentukan jumlah anggaran, dan kemudian menekankan jumlah tersebut pada tingkat yang lebih bawah.

- Pendekatan dari bawah ke atas, proses anggaran dimulai dari tingkat organisasi terendah dan naik ke atas. 
- Pendekatan partisipasi, orang yang akan menerima dana akan berpartisipasi dalam menentukan tingkat dana.

\section{Sifat Dan Bentuk Sistem Informasi Keuangan}

1. Sifat dari informasi yang terkandung di dalam Sistem Informasi Keuangan haruslah mengandung komponen di bawah ini:
a. Relevan dan Materialitas
b. Formal dan Substansi
c. Tingkat Kepercayaan
d. Bebas dari Bias
e. Dapat Diperbandingkan
f. Konsistensi
g. Dapat Dipahami

2. Adapun informasi-informasi yang diberikan pada sistem informasi keuangan, disajikan didalam berbagai bentuk seperti:
a. Bentuk laporan khusus.
b. Bentuk laporan periodik.
c. Hasil dari simulasi matematika.
d. Saran dari sistem pakar.
e. Dan komunikasi elektronik. 


\section{E. Fungsi, Tujuan dan Ruang Lingkup Sistem Informasi}

\section{Keuangan}

Adapun arahan untuk menunjukan fungsi-fungsi dan tujuan Sistem Informasi keuangan dengan pengertian yang telah dijelaskan sebelumnya, maka wujud Sistem Informasi keuangan secara administrasi tertera pada bentuk-bentuk formulir, buku - buku dan catatan - catatan akuntansi serta laporan laporan yang disajikan.

1. fungsi-fungsi tersebut adalah :

a. Untuk menentukan hasil dari pada pelaksanaan oprasi perusahaan, meliputi :

- Adanya pemisah keterangan jumlah barang dan uang dari catatan - catatan perusahaan.

- Membuat laporan untuk pemimpin.

b. Untuk dapat mengikuti jalanya harta dan hutang perusahaan. Di dalam fungsi ini meliputi pemeliharaan terhadap bermacam macam buku dan rekening seperti kas, rekening - rekening milik dan lain-lain.

c. Untuk mempermudah perencanaan kegiatankegiatan perusahaan, tindak lanjut dari pada pelaksanaan dan perbaikan dari rencanarencana. 
2. Tujuan Sistem Informasi Keuangan

Tujuan Sistem Informasi Keuangan menurut Baridwan (1996):

1. Untuk mendukung kegiatan operasi seharihari (to Support the day to day operations).

2. Mendukung dalam pengambilan keputusan manajemen (to support decision making by internal decision makers).

3. Untuk memenuhi segala kewajiban yang berhubungan dengan pertanggungjawaban (to fulfill obligations relating to stewardship).

Pada dasarnya penyusunan Sistem Informasi Keuangan suatu perusahaan mempunyai beberapa tujuan yang harus dipertimbangkan baik-baik, yaitu :

a. Sistem Informasi Keuangan yang disusun itu harus memenuhi prinsip cepat yaitu bahwa Standar Akuntansi Keuangan harus mampu menyediakan data yang diperlukan tepat pada waktunya dan dapat memenuhi kebutuhan.

b. Sistem Informasi keuangan yang disusun itu harus mempunyai prinsip aman yang berarti bahwa Sistem Inforamasi keuangan harus membantu menjaga harta milik perusahaan, 
untuk dapat menjaga keamanan harta milik perusahaan maka Sistem Informasi Akuntansi keuangan harus disusun dengn pertimbangan pengawasan - pengawasan intern.

c. Sistem Informasi keuangan yang disusun harus mempunyai prinsip murah yang berarti bahwa biaya untuk menyelenggarakan Sistem Informasi keuangan ini harus dapat ditekankan sehingga relatif tidak mahal

3. Ruang Lingkup Sistem Informasi Keuangan

a. Ruang lingkup Implementasi aplikasi Sikompak pada Bagian Akuntansi/Pembukuan meliputi pencatatan dan pengolahan data atas transaksi keuangan yang meliput penjurnalan. posting hingga menghasilkan laporan keuangan perusahaan (General Ledger System).

b. Ruang lingkup Sistem Informasi Aktiva Tetap dan Persediaan terdiri dari mutasi penambahan dan pengurangan pada aktiva tetap dan persediaan serta perhitungan penyusutan dan nilai buku aktiva tetap.

c. Ruang Lingkup implementasi Billing System yang telah terkomputerisasi terdiri dari beberapa sub-sistem antara lain sub-sistem 
penyambungan baru, sub-sistem administrasi rekening, sub-sistem pelayanan pelanggan (customer service) dan sub-sistem penagihan dan penerimaan kas.

\section{Kesimpulan}

Sistem Informasi Keuangan adalah sistem informasi yang memberikan informasi kepada orang atau kelompok baik di dalam perusahaan maupun di luar perusahaan mengenai masalah keuangan \& menyediakan informasi mengenai arus uang bagi para pemakai diseluruh perusahaan. Sistem informasi keuangan sering dibutuhkan dalam menghadapi dan memecahkan masalah yang muncul dalam perusahaan, terutama masalah keuangan. Informasi keuangan perusahaan yang dihasilkan harus berkualitas agar informasi tersebut bisa memiliki manfaat yang maksimal yang bisa diandalkan sebagai dasar pengambilan keputusan. Sehingga dengan adanya sistem informasi keuangan dapat mempermudah dan memenuhi kebutuhan manajer ataupun berbagai elemen dilingkungan perusahaan atas informasi yang menjelaskan status keuangan perusahaan. Model sistem informasi keuangan terdiri dari sub sistem input dan sub sistem output. 
Tujuan dari sistem informasi keuangan adalah untuk menyediakan data yang diperlukan tepat pada waktunya dan dapat memenuhi kebutuhan, untuk dapat menjaga keamanan harta milik perusahaan maka Sistem Informasi Akuntansi keuangan harus disusun dengan pertimbangan pengawasan-pengawasan intern, untuk menyelenggarakan Sistem Informasi keuangan ini harus dapat ditekankan sehingga relatif tidak mahal.

\section{SOAL}

1. Apa yang anda ketahui tentang sistem informasi keuangan?

2. Jelaskan perbedaan antara sistem informasi keuangan dengan sistem informasi akuntansi !

3. Jelaskan kriteria informasi keuangan agar dikatakan berkualitas!

4. Jelaskan tujuan umum sistem informasi keuangan!

5. Jelaskan siapa sajakah pihak yang memerlukan informasi keuangan!

6. Jelaskan karakteristik informasi keuangan yang bermanfaat bagi pembuatan keputusan!

7. Jelaskan model sistem informasi keuangan!

8. Jelaskan fungsi sistem informasi keuangan!

9. Sejauh mana peran sistem informasi keuangan bagi perusahaan? 
10. Jelaskan perbedaan antara informasi keuangan dan non keuangan serta berikancontohnya dalam perusahaan!

\section{Daftar Pustaka}

Baridwan, Z. (1996). Sistem Informasi Akuntansi. Yogyakarta: BPFE.

Rochaety, E., Setyowati, T., \& Ridwan, F. (2011). Sistem Informasi Manajemen. Jakarta: Mitra Wacana Media. 


\section{BAB 8}

\section{SISTEM INFORMASI EKSEKUTIF DAN SISTEM PENDUKUNG KEPUTUSAN}

\section{Tujuan instruksional}

Dengan membaca bab ini, mahasiswa diharapkan untuk mampu :

5. Memahami definisi sistem informasi eksekutif

6. Menjelaskan karakteristik sistem informasi eksekutif dan Modelnya

7. Memahami contoh sistem informasi eksekutif dalam organisasi

8. Memahami konsep dan manfaat sistem pendukung keputusan

\section{A. Pendahuluan}

Alasan mengapa teknologi informasi telah banyak digunakan dalam perusahaan dan organisasi adalah karena teknologi informasi terbukti mampu membantu eksekutif dalam mengambil keputusan. System informasi eksekutif dapat membantu para eksekutif dalam mengambil keputusan untuk kebutuhan bisnis organisasi secara tepat, akurat, dan cepat sesuai fakta dan data yang ada. Sistem informasi eksekutif juga mampu menyimpan data 
dan menyajikannya kembali menjadi informasi summary yang dapat didetil oleh eksekutif.

\section{B. Pengertian Sistem Informasi Eksekutif}

Sistem Informasi Eksekutif (SIE) adalah salah satu jenis manajemen sistem informasi untuk memudahkan dan mendukung keterangan dan pembuatan keputusan yang dibutuhkan eksekutif senior dengan menyediakan kemudahan akses terhadap informasi baik dari dalam maupun dari luar yang relevan dengan tujuan organisasi. Menurut Turban \& Aronson (2001) Sistem Informasi Eksekutif adalah suatu sistem berbasis komputer yang melayani kebutuhan informasi para Eksekutif tingkat atas (Top Executive), dimana sistem ini menyediakan akses yang cepat untuk memperoleh informasi yang tepat pada waktunya dan akses langsung kepada laporan - laporan manajemen.

Tingkatan manajemen terdiri dari Manajemen Tingkat Atas Sering disebut juga manajemen pada tingkat perencanaan strategis. Perencanaan strategis menunjukan pengaruh yang timbul dari keputusankeputusan pada seluruh organisasi pada tahun tahun mendatang. Manajemen Tingkat Menengah mencakup manajer wilayah, direktur produk dan kepala divisi. Manajemen Tingkat Bawah Mencakup 
kepala departemen, supervisor, dan pemimpin proyek, yang bertanggungjawab menyelesaikan rencana-rencana yang telah ditetapkan oleh para manajer ditingkat yang lebih tinggi sering disebut juga tingkat pengendalian operasional.

\section{Karakteristik dan Model Sistem Informasi Eksekutif} (SIE)

1. Karakteristik Sistem Informasi Eksekutif

a. Disesuaikan dengan pemakai eksekutif perorangan. Mengekstrasi, menyaring, meringkas, dan menangkap data-data yang penting.

b. Memberikan akses status online, pelaporan kekecualian, analisa trend, dan drill down (memungkinkan pemakai dalam mengakses kerincian atau data pendukung yang berada di bawah yang teringkas).

c. Mengakses dan memadukan jangkauan data internal dengan eksternal bersifat luas.

d. Bersifat user friendly dan dalam menggunakannya hanya dibutuhkan keterampilan yang dapat dilakukan tanpa pelatihan.

e. Digunakan secara langsung oleh eksekutif tanpa perantara. 
f. Menampilkan informasi berupa grafik, tabuler, dan tekstual.

2. Model Sistem Informasi Eksekutif

Menurut Mcleod \& Schell (2001) Model Sistem Informasi Eksekutif adalah suatu model rancangan atau konfigurasi hardware yang mempunyai hubungan satu sama lain sehingga membentuk suatu informasi Eksekutif yang berbasiskan komputer.

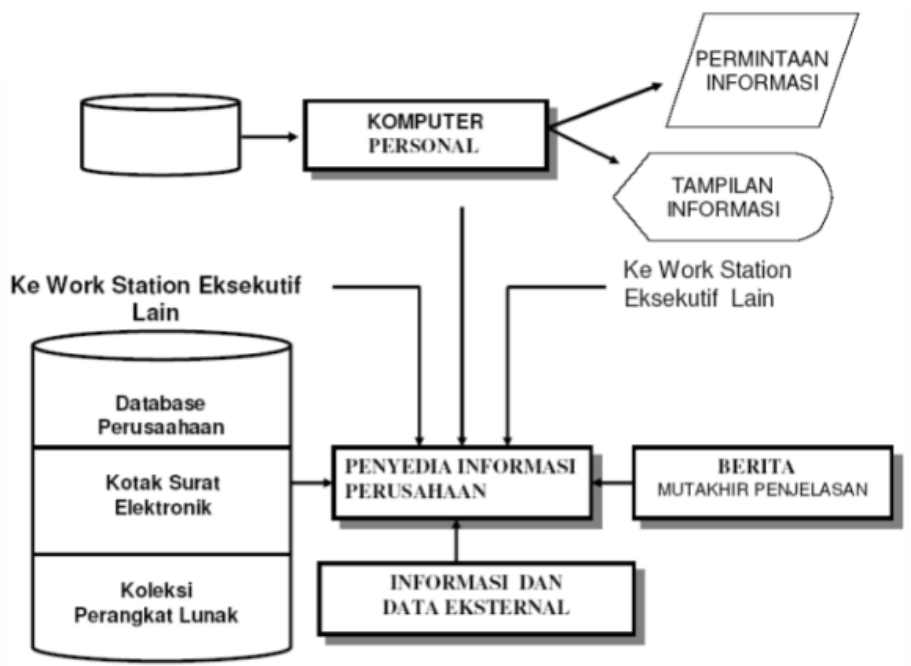

Gambar 1

Mosel Sistem Informasi Eksekutif 


\section{Penerapan SIE Pada suatu Organisasi}

Untuk para eksekutif yang tertarik untuk menggunakan sistem informasi eksekutif (melalui Divisi Teknologi Informasi internal perusahaan), ada hal-hal yang harus diperhatikan untuk menjamin efektivitas sistem sesuai dengan yang diharapkan.

1. Hakekat atau nature dari SIE itu sendiri. Dalam hirarki sistem informasi, sistem informasi eksekutif adalah suatu sistem yang dapat menghasilkan laporan informasi yang tertinggi dalam perusahaan. Perangkat sistem informasi eksekutif melakukan penarikan data (data warehouse) dan mensarikannya (data summarizing) dari suatu sumber data tertentu atau database yang ada di bawahnya. Yang artinya apabila perusahaan yang ingin menggunakan perangkat SIE maka perusahaan sudah harus memiliki suatu gudang data (data warehouse) terlebih dahulu. Perusahaan harus memastikan bahwa sistem SIE yang akan dikembangkan dapat mengakses sistem basis data (database system) yang ada dengan mudah. Jika tidak, maka terpaksa harus dikembangkan suatu sistem antarmuka (interface) tertentu untuk menjembatani kedua hal tersebut. 
2. Features yang harus tersedia dalam suatu paket sistem informasi eksekutif. Setiap eksekutif memiliki caranya masing-masing yang berbeda dalam mengambil suatu keputusan, sehingga bentuk penyajian informasi pada SIE juga harus disesuaikan dengan karakteristik eksekutif tersebut. Beberapa ada yang menyukai bentuk grafik (batang, garis, lingkaran, dsb.) namun ada juga yang lebih memilih dalam bentuk angkaangka sederhana. Paket system informasi eksekutif yang dibeli atau dikembangkan diharapkan dapat mengakomodasikan kepentingan dari perusahaan.

3. Masih berkaitan dengan features system informasi eksekutif yaitu kemampuan untuk melakukan pembuatan informasi yang disajikan dalam bentuk gambar dan angka-angka yang informatif secara cepat. Seorang Direktur terkadang dihadapkan pada suatu hal-hal yang bersifat prioritas pada masa-masa tertentu. Bentuk laporan SIE pada saat akhir bulan mungkin tidak sama dengan yang dibutuhkan per hari atau pada suatu saat tertentu. Dan di sinilah diperlukan fasilitas-fasilitas pada modul SIE yang diharapkan dapat mempermudah pembuatan laporan-laporan bagi eksekutif secara cepat dan 
variatif. Seorang eksekutif sering di hadapkan pada suatu keadaan dimana harus mengontrol beberapa hal di saat yang bersamaan. SIE yang baik diharuskan tetap mempertahankan kesederhanaan dalam melakukan pembuatan laporan walaupun data yang digunakan atau masalah yang dihadapi terasa rumit/kompleks. Fasilitas customizable ini juga dibutuhkan sesuai dengan keperluan eksekutif yang dapat berubahubah dengan cepat dari waktu ke waktu, terutama dalam kondisi bisnis yang serba dinamik.

\section{E. Konsep dan Manfaat Sistem Pendukung Keputusan}

1. Konsep Sistem Pendukung Keputusan

Sistem Pendukung Keputusan (SPK) atau decision support systems (DSS) merupakan bagian dari sistem informasi berbasis komputer (termasuk berbasis pengetahuan) yang dipakai untuk mendukung pengambilan keputusan dalam suatu organisasi atau perusahaan.

SPK memiliki lima karakter pokok (Sprague \& Watson, 1993) antara lain:

a. Dilakukan oleh sistem berbasis komputer.

b. Digunakan untuk membantu pengambilan keputusan. 
c. Digunakan untuk memecahkan masalah rumit yang mustahil dilakukan dengan kalkulasi manual atau riset literasi yang sederhana.

d. Melalui cara simulasi yang interaktif.

e. Data dan model analisis sebagai komponen utama.

2. Manfaat Menggunakan Sistem Pendukung Keputusan

a. Di dalam perusahaan, sistem pendukung keputusan ini juga bisa diterapkan untuk memantau perkembangan karyawan. Misalnya, dalam memilih karyawan yang sesuai kriteria atau keterampilan yang sedang dibutuhkan perusahaan.

b. Bentuk profile-matching ini bisa diterapkan untuk meningkatkan efisiensi kerja perusahaan. Dari berbagai variabel yang dimasukkan, SPK bisa membantu memutuskan karyawan mana yang pantas mendapat kenaikan jabatan atau menentukan perencanaan karier yang terukur.

c. SPK bisa juga memberi rekomendasi atas pengisian jabatan atau posisi pekerjaan yang kosong. Meski tidak memberikan solusi final, 
namun SPK mampu memudahkan kinerja direksi perusahaan.

Secara umum manfaat SPK adalah memperluas kemampuan pengambilan keputusan dalam memproses data dan informasi bagi pemakainya. SPK juga bisa membantu mengambil keputusan dalam memecahkan permasalahan yang terstruktur atau tidak terstruktur.

\section{Kesimpulan}

Sistem Informasi Eksekutif (SIE) merupakan salah satu jenis manajemen sistem informasi untuk memudahkan dan mendukung pembuatan keputusan yang dibutuhkan eksekutif senior dengan menyediakan kemudahan akses terhadap informasi baik dari dalam maupun dari luar yang relevan dengan tujuan organisasi. Karakteristik dari Sistem Informasi Eksekutif adalah menyesuaikan dengan pemakai eksekutif perorangan, memberikan akses status online, mengakses dan memadukan jangkauan data internal dengan eksternal bersifat luas, bersifat user friendly, digunakan secara langsung oleh eksekutif tanpa intermediary (perantara), dan menampilkan informasi grafik, tabuler, tekstual.

Sistem Pendukung Keputusan (SPK) atau decision support systems (DSS) merupakan bagian dari sistem 
informasi berbasis komputer (termasuk berbasis pengetahuan) yang dipakai untuk mendukung pengambilan keputusan dalam suatu organisasi atau perusahaan. Karakter pokok system pendukung keputusan yakni dilakukan oleh sistem berbasis komputer, digunakan untuk membantu pengambilan keputusan, digunakan untuk memecahkan masalah rumit yang mustahil dilakukan dengan kalkulasi manual atau riset literasi yang sederhana, melalui cara simulasi yang interaktif, dan data dan model analisis sebagai komponen utama. Secara umum manfaat SPK adalah memperluas kemampuan pengambilan keputusan dalam memproses data dan informasi bagi pemakainya. SPK juga bisa membantu mengambil keputusan dalam memecahkan permasalahan yang terstruktur atau tidak terstruktur.

\section{SOAL}

1. Apa yang anda ketahui tentang sistem informasi eksekutif ?

2. Apa pentingnya sistem informasi eksekutif bagi perusahaan atau organisasi ?

3. Apa yang perlu dilakukan perusahaan apabila ingin menerapkan sistem informasi eksekutif ?

4. Apa saja faktor-faktor penentu yang dapat menunjang keberhasilan sistem informasi eksekutif? 
5. Jelaskan bagaimana model sistem informasi eksekutif !

6. Jelaskan karakteristik dari sistem informasi eksekutif!

7. Jelaskan keuntungan dan kerugian dari penggunaan sistem informasi eksekutif !

8. Bagaimana peran sistem informasi eksekutif untuk kecenderungan masa depan?

9. Jelaskan komponen dari sebuah sistem informasi eksekutif !

10. Apa perbedaan dari sponsor eksekutif dengan sponsor operasi dalam faktor penentu keberhasilan penerapan sistem informasi eksekutif ?

\section{Daftar Pustaka}

Mcleod, J. R., \& Schell, G. (2001). Management Information System. New Jersey: Prentice Hall International Inc.

Sprague, R. H., \& Watson, H. J. (1993). Decision Support

Systems: Putting Theory Into Practice. New Jersey:

Prentice Hall.

Turban, E., \& Aronson, J. E. (2001). Decision Support

Systems and Intelligent Systems. Upper Saddle River, NJ: Prentice Hall. 


\section{BAB 9}

\section{SISTEM INFORMASI AKUNTANSI}

\section{Tujuan instruksional}

Dengan membaca bab ini, mahasiswa diharapkan untuk mampu :

5. Memahami definisi sistem informasi akuntansi

6. Menjelaskan fungsi sistem informasi akuntansi

7. Menjelaskan jenis sistem informasi akuntansi

8. Menjelaskan bagian-bagian dan keandalan sistem informasi akuntansi

\section{A. Pendahuluan}

Pada era ini akuntansi telah mengalami banyak evolusi. Dahulu akuntansi diartikan sebagai seni dalam mencatat, mengelompokkan, meringkas dan melaporkan transaksi (peristiwa) bisnis. Penggunaan dari istilah sistem dalam akuntansi lebih banyak ditekankan kepada prosedur atau proses akuntansi yang terintegrasi antara sub-sub dalam sistem akuntansi. Sistem informasi yang menghasilkan informasi semacam itu disebut sebagai sistem informasi akuntansi (SIA). Kita mungkin terlibat di dalam sistem informasi akuntansi sebagai penerima informasi. Dilain pihak, Kita mungkin menggunakan 
SIA pada tingkatan yang lebih luas di dalam manajamen perusahaan. Sebagai contoh kita selalu mencatat setiap transaksi yang terjadi ke dalam jurnal-jurnal dan menyiapkan laporan keuangan atas semua transaksi atau aktivitas bisnis yang telah dilakukan.

\section{B. Pengertian Sistem Informasi Akuntansi}

Menurut Bodnar \& Hopwood (2010) Sistem informasi akuntansi adalah kumpulan sumber daya, seperti orang dan peralatan, yang dirancang untuk mengubah data keuangan dan data lainnya menjadi informasi. Informasi ini kemudian dikomunikasikan kepada berbagai pengambil keputusan. Sistem informasi akuntansi melakukan transformasi ini untuk menentukan sistem dasar mereka manual atau komputerisasi secara menyeluruh. Sistem Informasi Akuntansi didefinisikan sebagai suatu sistem yang terdiri dari berbagai formulir, catatan dan laporan yang disusun dan menghasilkan suatu informasi keuangan yang dibutuhkan oleh perusahaan. Dengan begitu manajemen perusahaan dapat melihat dengan jelas bagaimana kondisi keuangan perusahaan melalui sistem tersebut. Dari sistem 
yang digunakan manajemen juga dapat mengontrol bagaimana kinerja sistemnya.

Sistem informasi akuntansi memiliki enam komponen yang saling terkait dan berinteraksi untuk mencapai tujuan. Menurut Romney \& Steinbart (2012) keenam komponen tersebut, yaitu :

1. User atau pengguna sistem.

2. Prosedur dan instruksi-instruksi yang digunakan untuk mengumpulkan, memproses, dan menyimpan data.

3. Data mengenai organisasi dan aktivitas bisnis dalam perusahaan.

4. Software yang digunakan untuk melakukan pemprosesan data.

5. Infrastruktur teknologi informasi yang terdiri dari komputer, peripheral devices, dan perangkat jaringan komunikasi yang digunakan sistem informasi akuntansi.

6. Keamanan dan pengendalian internal yang digunakan untuk mengamankan data sistem informasi akuntansi.

\section{Fungsi Sistem Informasi Akuntansi}

Sistem Informasi Akuntansi sangat diperlukan oleh organisasi perusahaan. Tujuan utama dibangunnya sistem informasi akuntansi adalah untuk mengolah data akuntansi yang berasal dari 
berbagai sumber menjadi informasi akuntansi yang diperlukan oleh berbagai macam pemakai informasi untuk mengurangi resiko pada saat pengambilan keputusan. Para pemakai informasi dapat berasal dari dalam perusahaan seperti manajer maupun dari luar perusahaan seperti pelanggan dan pemasok. Sistem informasi akuntansi memiliki beberapa fungsi dalam keberlangsungan usaha. Berikut beberapa fungsinya:

1. Mengumpulkan semua data kegiatan bisnis perusahaan dan menyimpan data tersebut secara efektif dan efisien. Selain itu, SIA juga dapat mencatat semua sumber daya yang berpengaruh terhadap usaha tersebut dan semua pihak yang terkait. Dengan fungsi ini, tidak akan ada suatu hal dalam perusahaan yang tidak tercatat.

2. Mengambil data yang diperlukan dari berbagai sumber dokumen yang berkaitan dengan aktivitas bisnis. Data yang sudah tersimpan akan lebih mudah diambil karena setiap detail dari data sudah terekam dengan SIA.

3. Membuat dan mencatat data transaksi dengan benar ke dalam jurnal-jurnal yang diperlukan dalam proses akuntansi sesuai dengan urutan dan tanggal terjadinya transaksi. Pencatatan ini bertujuan untuk mempermudah pihak-pihak 
yang bersangkutan dalam pengecekan semua transaksi sehingga apabila terjadi suatu kesalahan maka dapat dikoreksi dengan mudah dan dapat diketahui penyebabnya dengan cepat.

4. Mengubah sekumpulan data menjadi sebuah informasi keuangan yang dibutuhkan perusahaan. Informasi ini berbentuk laporan keuangan baik secara manual maupun secara online yang dibutuhkan oleh berbagai pihak.

5. Sebagai pengendali keuangan agar tidak terjadi suatu kecurangan. Dengan sistem ini, keuangan perusahaan dapat dilacak dengan pasti karena sistem pertanggungjawaban yang lebih detail. Fungsi ini diharapkan dapat menjaga aset perusahaan dan mengurangi risiko-risiko penggelapan aset oleh semua pihak terkait.

\section{Jenis Sistem Informasi Akuntansi}

Terdapat dua jenis sistem informasi akuntansi, yakni :

1. Sistem Informasi Akuntansi Manual

Menurut Hall (2007) Sistem informasi akuntansi manual merupakan proses pencatatan dengan menggunakan dokumen, jurnal, dan buku besar.

a. Dokumen terbagi menjadi tiga jenis, yaitu dokumen sumber, dokumen produk, dan dokumen perputaran. 
- Dokumen sumber adalah dokumen yang diciptakan pada awal transaksi melalui peristiwa ekonomi.

- Dokumen produk adalah dokumen hasil dari pemrosesan transaksi, bukan dokumen yang memicu proses.

- Dokumen perputaran adalah dokumen produk dari satu sistem yang menjadi dokumen sumber dari sistem lainnya.

b. Jurnal (journal) adalah catatan ayat-ayat secara kronologis. Pada titik tertentu dalam proses transaksi, ketika semua fakta yang relevan tentang transaksi diketahui, peristiwa dicatat dalam jurnal secara kronologis. Terdapat dua jenis jurnal, yaitu jurnal khusus dan jurnal umum.

- Jurnal khusus digunakan untuk mencatat kelas transaksi khusus yang muncul dalam volume besar.

- Jurnal umum digunakan untuk mencatat transaksi yang jarang terjadi atau transaksi yang tidak sama.

c. Buku besar (ledger) adalah buku akun keuangan yang mencerminkan pengaruh keuangan dari transaksi setelah dibukukan dari berbagai jurnal. Terdapat dua jenis buku 
besar yakni buku besar umum dan buku besar pembantu.

- Buku besar umum (general ledger) yakni buku yang merangkum aktivitas dari setiap akun perusahaan.

- Buku besar pembantu (subsidiaryledger) yakni buku yang mencakup persediaan, utang, penggajian, dan piutang.

2. Sistem Informasi Akuntansi Berbasis Komputer Menurut Hall (2007) Sistem informasi akuntansi berbasis komputer adalah suatu proses pencatatan yang menggunakan bantuan dari komputer. Pencatatan akuntansi dalam sistem berbasis komputer ini disajikan dalam empat jenis file magnetis, yaitu:

a. File master (master file), biasanya berisi mengenai data akun. Buku besar umum dan buku besar pembantu merupakan contoh dari file master. Nilai data dalam file master diperbarui dari proses transaksi.

b. File transaksi (transaction file), file sementara untuk menyimpan catatan transaksi yang akan digunakan untuk mengubah atau memperbarui sebuah data dalam file master. Contoh dari file transaksi 
adalah pesanan penjualan, penerimaan persediaan, dan penerimaan kas.

c. File referensi (reference file), menyimpan data yang akan digunakan sebagai standar dalam memproses transaksi. File referensi terdiri dari daftar harga yang digunakan untuk menyiapkan faktur pelanggan, daftar pemasok yang telah diotorisasi, jadwal karyawan, dan file kredit pelanggan untuk persetujuan dalam penjualan kredit.

d. File arsip (archive file), berisi mengenai catatan transaksi masa lalu yang disimpan untuk referensi di masa depan. File arsip meliputi jurnal, informasi penggajian dari periode sebelumnya, daftar nama-nama karyawan sebelumnya, catatan mengenai akun yang dihapus, dan buku besar pada periode sebelumnya.

\section{E. Bagian - Bagian dan Keandalan Sistem Informasi Akuntansi}

1. Bagian - bagian sistem informasi akuntansi

- People : pengguna yang mengoperasikan sistem dan melakukan berbagai fungsi.

- Procedure : prosedur dalam mengumpulkan, memproses dan menyimpan data yang berhubungan dengan aktivitas perusahaan. 
- Data : informasi dari kegiatan atau proses bisnis.

- Software : perangkat yang digunakan untuk memproses data yang ada di organisasi.

- Infrastruktur Informasi Teknologi : komputer dan peralatan lainnya.

2. Keandalan sistem informasi akuntansi Menurut American Institute of CPA (AICPA) dan Canadian Institute of Chartered Accountants (CICA), terdapat prinsip dasar yang penting dalam keandalan sistem, yaitu :

- Keamanan : Pembatasan akses ke sistem dan datanya untuk dikontrol dan dibatasi hanya bagi pihak yang berwenang.

- Kerahasiaan : Perlindungan dan penjagaan informasi sensitif untuk menghindari dari pengungkapan yang tidak sah.

- Privasi : Cara yang tepat dan privat dalam pengumpulan, penggunaan, dan pengungkapan informasi pribadi tentang pelanggan.

- Memproses integritas : Otorisasi yang tepat dalam pemrosesan data yang akurat, lengkap, dan tepat waktu. 
- Ketersediaan : Sistem ini tersedia untuk memenuhi kewajiban operasional sesuai dengan kontrak.

\section{Kesimpulan}

Sistem Informasi Akuntansi merupakan suatu sistem yang terdiri dari berbagai formulir, catatan dan laporan yang telah disusun dan menghasilkan suatu informasi keuangan yang dibutuhkan oleh perusahaan. Dengan demikian manajemen perusahaan dapat melihat keuangan dengan jelas melalui sistem tersebut. Sistem informasi akuntansi yang menyediakan informasi memiliki beberapa fungsi dalam keberlangsungan usaha yakni mengumpulkan semua data kegiatan bisnis perusahaan dan menyimpan data tersebut secara efektif dan efisien, mengambil data yang dibutuhkan dari berbagai sumber yang berkaitan dengan aktivitas bisnis, membuat dan mencatat data transaksi dengan benar sesuai dengan urutan dan tanggal terjadinya transaksi ke dalam jurnal-jurnal yang diperlukan dalam proses akuntansi, mengubah sekumpulan data menjadi sebuah informasi keuangan yang dibutuhkan perusahaan, dan sebagai suatu sistem pengendali keuangan agar tidak terjadi suatu kecurangan. 
Terdapat dua jenis sistem informasi akuntansi yakni sistem informasi akuntansi manual dan sistem informasi akuntansi berbasis komputer. Yang merupakan bagian dari SIA adalah people, prosedur, data, software dan infrastruktur informasi teknologi. Keandalan SIA dapat dilihat dari keamanan, kerahasiaan, privasi, integritas, dan ketersediaan.

\section{SOAL}

1. Jelaskan apa yang dimaksud dengan sistem informasi akuntansi !

2. Jelaskan peran sistem informasi akuntansi bagi perusahaan atau organisasi !

3. Sebut dan jelaskan siapa sajakah yang merupakan pengguna sistem informasi akuntansi !

4. Jelaskan fungsi dari sistem informasi akuntansi !

5. Sebut dan jelaskan jenis sistem informasi akuntansi !

6. Jelaskan manfaat komputer dalam sistem informasi akuntansi !

7. Mengapa pengawasan diperlukan di dalam SIA, jelaskan!

8. Jelaskan apa saja yang menjadi bagian dalam sistem informasi akuntansi !

9. Jelaskan kelebihan dan kelemahan dari sistem informasi akuntansi ! 
10. Jelaskan prinsip dasar keandalan sistem informasi akuntansi !

\section{Daftar Pustaka}

Bodnar, G. H., \& Hopwood, W. S. (2010). Accounting Information System. United State of America: Pearson Education Inc.

Hall, J. A. (2007). Sistem Informasi Akuntansi. Jakarta: Salemba Empat.

Romney, M. B., \& Steinbart, P. J. (2012). Accounting Information System. London: Prentice Hall. 


\section{BAB 10}

\section{TEKNIK DOKUMENTASI DAN PENGEMBANGAN SISTEM}

\section{Tujuan instruksional}

Dengan membaca bab ini, mahasiswa diharapkan untuk mampu :

5. Memahami definisi dokumentasi dan pengembangan sistem

6. Memahami dan menjelaskan data flow diagram

7. Memahami dan menjelaskan data flowchart

8. Menjelaskan teknik pengembangan sistem

\section{A. Pendahuluan}

Dokumentasi meliputi bentuk naratif, bagan alir (flowchart), diagram, dan materi tertulis lainnya, yang menjelaskan bagaimana sebuah sistem bekerja. Informasi ini meliputi siapa, apa, kapan, di mana, mengapa, dan bagaimana data dimasukkan (data entry), diproses, disimpan, menghasilkan informasi, serta bagaimana pengendalian sistemnya. Sistem merupakan suatu kesatuan yang terdiri dari komponen atau elemen yang dihubungkan bersamasama untuk memudahkan aliran informasi, materi ataupun energi untuk mencapai suatu tujuan. Istilah ini sering dipergunakan untuk menggambarkan suatu 
entitas yang berinteraksi, di mana suatu model matematika seringkali bisa dibuat. Interaksi antar komponen yang saling berhubungan perlu digambarkan untuk memudahkan perbaikan kesalahan sistem, atau untuk mempermudah pengembangan sistem.

\section{B. Pengertian Dokumentasi dan Pengembangan}

\section{Sistem}

Dokumentasi merupakan bagan, arus, diagram dan penjelasan tertulis yang menjelaskan cara kerja sebuah sistem. Pengertian dokumentasi dibedakan menjadi dua arti, yaitu arti sempit dan arti luas. Dokumentasi dalam arti sempit adalah barangbarang atau benda-benda tertulis, sedangkan dokumentasi dalam arti luas adalah dokumen bukan hanya berwujud tulisan saja tetapi dapat berupa benda-benda peninggalan seperti prasasti dan simbol-simbol lainnya (Widoyoko, 2015). Dokumentasi harus menjelaskan who, what, why, when, and where of systems. Dokumentasi diperlukan untuk merancang sebuah sistem sebagai media komunikasi antar perancang, analis, atau programmer. Dokumentasi juga dapat digunakan untuk mengevaluasi kelemahan dan keunggulan 
suatu sistem oleh analis dan auditor. Dokumentasi juga dapat menjadi media pelatihan karyawan baru.

Pengembangan sistem dapat berarti menyusun suatu sistem yang baru untuk menggantikan sistem yang lama secara keseluruhan atau memperbaiki sistem yang telah ada. Pengembangan sistem menjadi perlu apabila diperlukan informasi baru dari sistem baru. Selain itu, pengembangan sistem diperlukan untuk meningkatkan efektifitas pengendalian akuntansi, perbaikan sistem dan untuk efisiensi biaya.

\section{Diagram Alir Data (DFD)}

Menurut Fatta \& Marco (2015) Data Flow Diagram (DFD) merupakan suatu bagan untuk mewakili arus atau aliran data dalam suatu sistem. Diagram Alir Data (Data Flow Diagram (DFD)) adalah suatu diagram yang menggunakan notasi-notasi untuk menggambarkan arus dari data sistem, yang penggunaannya sangat membantu untuk memahami sistem secara logika, tersruktur dan jelas. DFD merupakan alat bantu dalam menggambarkan atau menjelaskan. DFD ini sering disebut juga dengan nama Bubble chart, Bubble diagram, model proses, diagram alur kerja, atau model fungsi. DFD menggambarkan arus data dari suatu sistem 
informasi, baik sistem lama maupun sistem baru secara logika tanpa mempertimbangkan lingkungan fisik dimana data tersebut berada.

Untuk membaca suatu DFD kita harus memahami dulu elemen-elemen yang menyusun suatu DFD. Ada empat elemen yang menyusun suatu DFD (Fatta, 2007), yaitu :

\section{Proses}

Aktivitas atau fungsi yang dilakukan untuk alasan bisnis yang spesifik, biasa berupa manual maupun terkomputerisasi.

2. Data Flow

Suatu data tunggal atau kumpulan logis suatu data, selalu diawali atau berakhir pada suatu proses.

3. Data Store

Kumpulan data yang disimpan dengan cara tertentu. Data yang mengalir disimpan dalam data store. Aliran data di-update atau ditambah data store.

4. External Entity

Orang, organisasi, atau sistem yang berada diluar sistem tetapi berinteraksi dengan sistem.

Masing-masing elemen pada diagram diberikan simbol-simbol tertentu untuk membedakan satu dengan yang lain. Adapun simbol-simbol yang 
digunakan pada data flow diagram adalah sebagai berikut :

\begin{tabular}{|c|c|c|}
\hline Gane/Sarson & Yourdon/De Marco & Keterangan \\
\hline $\begin{array}{c}\text { Entitas } \\
\text { Ekstemal }\end{array}$ & $\begin{array}{c}\text { Entitas } \\
\text { Ekstemal }\end{array}$ & $\begin{array}{l}\text { Entitas ekstemal dapat } \\
\text { benupa orang/unit terkait } \\
\text { yang berinterkasi dengan } \\
\text { sistem tetapi di luar } \\
\text { sistem. }\end{array}$ \\
\hline Proses & Proses & $\begin{array}{l}\text { Orang/unit yang } \\
\text { mempergunakan atau } \\
\text { melakukan transformasi } \\
\text { data. Komponen fisik } \\
\text { tidak diidentifikasikan. }\end{array}$ \\
\hline$\stackrel{\text { Aliran Data }}{\longrightarrow}$ & $\stackrel{\longrightarrow}{\longrightarrow}$ & $\begin{array}{l}\text { Aliran data dengan arah } \\
\text { khusus dari sumber ke } \\
\text { tujuan }\end{array}$ \\
\hline Data Store & Data Store & $\begin{array}{l}\text { Penyimpanan data atau } \\
\text { tempat data dilihat oleh } \\
\text { proses. }\end{array}$ \\
\hline
\end{tabular}

Gambar 1

Daftar simbol-simbol data flow diagram

\section{Data Flowchart (Bagan Alir)}

Menurut Romney \& Steinbart (2014) bagan alir (flowchart) merupakan teknik analitis bergambar yang digunakan untuk menjelaskan tentang 
prosedur-prosedur yang terjadi di dalam perusahaan secara ringkas dan jelas. Bagan alir (flowchart) biasanya digambar dengan menggunakan software seperti Microsoft Visio, Microsoft Word, ataupun Microsoft Power Point. Flowchart adalah tipe diagram yang merepresentasikan alogritma, workflow proses dan langkah-langkah pada setiap jenis kotak yang berbeda. Flowchart digunakan untuk mempermudah perancangan sistem. Data flowchart memberikan ilustrasi yang jelas dalam memvisualisasikan suatu sistem.

Menurut Romney \& Steinbart (2014) simbol bagan alir (flowchart) dibagi menjadi 4 kategori yaitu simbol input/output, simbol pemrosesan, simbol penyimpanan, simbol arus dan lain-lain.

1. Simbol input/output memperlihatkan input/output dari suatu sistem.

2. Simbol pemrosesan memperlihatkan data-data yang sedang diolah di dalam sistem, data tersebut dapat diolah secara elektronik ataupun dengan tangan.

3. Simbol penyimpanan memperlihatkan dimana data-data perusahaan disimpan.

4. Simbol arus dan lain-lain memperlihatkan arus data, darimana bagan alir dimulai dan berakhir, bagaimana suatu keputusan dibuat dan cara-cara 


\section{yang digunakan untuk menambah catatan}

\section{penjelas untuk bagan alir.}

\section{Simbol-simbol umum dan penjelasan yang}

\section{terdapat di dalam bagan alir dapat dilihat pada}

\section{gambar dibawah ini.}

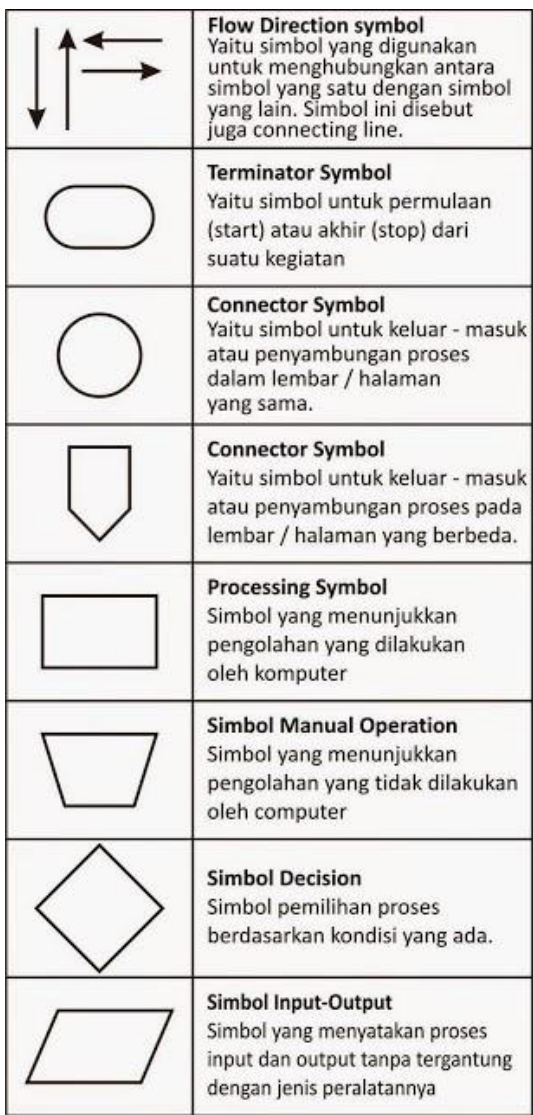

\begin{tabular}{|c|c|}
\hline & $\begin{array}{l}\text { Simbol Manual Input } \\
\text { Simbol untuk pemasukan data } \\
\text { secara manual on-line keyboard }\end{array}$ \\
\hline & $\begin{array}{l}\text { Simbol Preparation } \\
\text { Simbol untuk mempersiapkan } \\
\text { penyimpanan yang akan } \\
\text { digunakan sebagai tempat } \\
\text { pengolahan di dalam storage. }\end{array}$ \\
\hline & $\begin{array}{l}\text { Simbol Predefine Proses } \\
\text { Simbol untuk pelaksanaan suatu } \\
\text { bagian (sub-program)/prosedure }\end{array}$ \\
\hline & $\begin{array}{l}\text { Simbol Display } \\
\text { Simbol yang menyatakan peralatan } \\
\text { output yang digunakan yaitu layar, } \\
\text { plotter, printer dan sebagainya. }\end{array}$ \\
\hline & $\begin{array}{l}\text { Simbol disk and On-line Storage } \\
\text { Simbol yang menyatakan input } \\
\text { yang berasal dari disk atau } \\
\text { disimpan ke disk. }\end{array}$ \\
\hline & $\begin{array}{l}\text { Simbol magnetik tape Unit } \\
\text { Simbol yang menyatakan input } \\
\text { berasal dari pita magnetik atau } \\
\text { output disimpan ke pita magnetik }\end{array}$ \\
\hline & $\begin{array}{l}\text { Simbol Punch Card } \\
\text { Simbol yang menyatakan bahwa } \\
\text { input berasal dari kartu atau } \\
\text { output ditulis ke kartu }\end{array}$ \\
\hline & $\begin{array}{l}\text { Simbol Dokumen } \\
\text { Simbol yang menyatakan input } \\
\text { berasal dari dokumen dalam } \\
\text { bentuk kertas atau output } \\
\text { dicetak ke kertas. }\end{array}$ \\
\hline
\end{tabular}

Gambar 2

Daftar simbol-simbol flowchart 


\section{E. Pengembangan Sistem}

Terdapat dua bagan penting dalam pengembangan sistem, diantaranya IPO (input process output) dan HIPO (hierarchy plus input process output). Bagan IPO dapat mendeskripsikan masukan yang dibutuhkan untuk menghasilkan keluaran slstem yang diinginkan. Bagan HIPO memberikan rincian tambahan atas proses pada bagian bagan IPO.

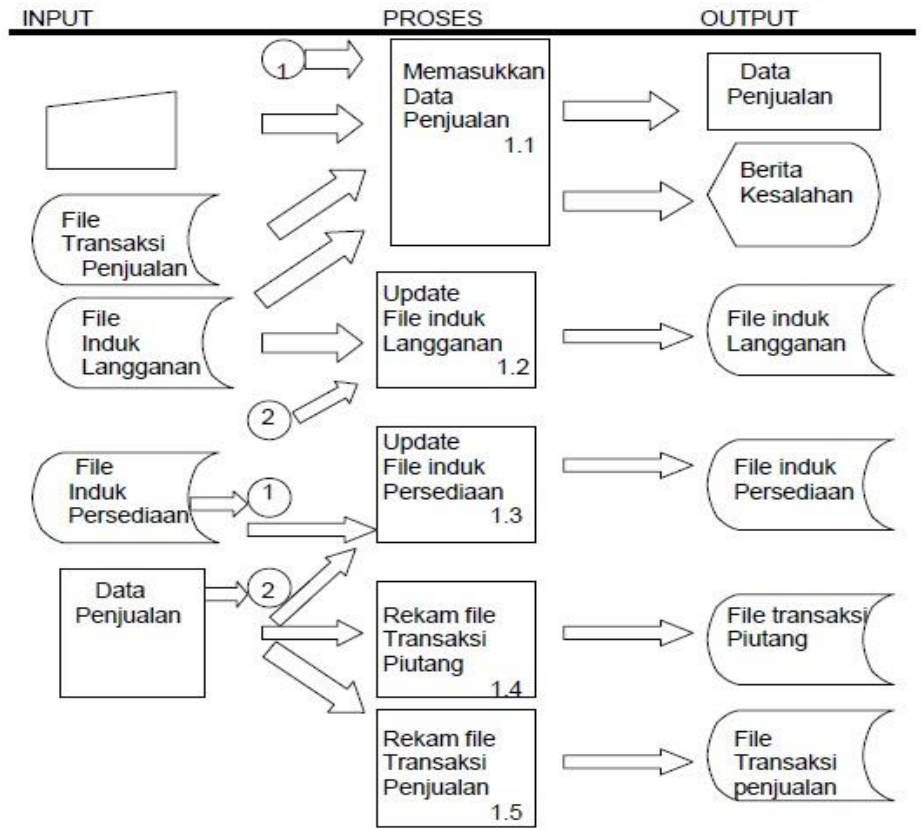

Gambar 3

Bagan IPO dan HIPO 
Prinsip dasar pengembangan sistem adalah :

1. Sistem yang dikembangkan adalah untuk manajemen

2. Sistem yang dikembangkan adalah investasi modal yang besar Investasi modal harus mempertimbangkan 2 hal, yaitu :

a. Semua alternatif yang ada harus diinvestigasi

b. Investasi yang terbaik harus bernilai

3. Sistem yang dikembangkan memerlukan orang yang terdidik

4. Proses pengembangan sistem tidak harus urut

5. Jangan takut membatalkan proyek

6. Dokumentasi harus ada untuk pedoman dalam pengembangan sistem.

Tahapan utama siklus hidup Pengembangan Sistem terdiri dari :

1. Perencanaan Sistem (Systems Planning)

2. Analisis Sistem (System Analysis)

3. Perancangan Sistem (Systems Design) Secara Umum

4. Seleksi Sistem (System Selection)

5. Perancangan Sistem (Systems Design) Secara Umum 
6. Implementasi dan Pemeliharaan Sistem (System Implementation \& Maintenance)

\section{Kesimpulan}

Dokumentasi meliputi bentuk naratif, bagan alir (flowchart), diagram, dan materi tertulis lainnya, yang menjelaskan bagaimana sebuah sistem bekerja. Informasi ini meliputi siapa, apa, kapan, di mana, mengapa, dan bagaimana data dimasukkan (data entry), diproses, disimpan, menghasilkan informasi, serta bagaimana pengendalian sistemnya.

Data Flow Diagram (DFD) adalah suatu diagram yang menggunakan notasi-notasi untuk menggambarkan arus dari data sistem, yang penggunaannya sangat membantu untuk memahami sistem secara logika, tersruktur dan jelas.

Flowchart adalah tipe diagram yang merepresentasikan alogritma, workflow proses dan langkah-langkah pada setiap jenis kotak yang berbeda. Flowchart digunakan untuk mempermudah perancangan sistem. Data flowchart memberikan ilustrasi yang jelas dalam memvisualisasikan suatu sistem.

Pengembangan sistem dapat berarti menyusun suatu sistem yang baru untuk menggantikan sistem yang lama secara keseluruhan atau memperbaiki sistem yang telah ada. Pengembangan sistem menjadi perlu apabila 
diperlukan informasi baru dari sistem baru. Selain itu, pengembangan sistem diperlukan untuk meningkatkan efektifitas pengendalian akuntansi, perbaikan sistem dan untuk efisiensi biaya.

\section{SOAL}

1. Jelaskan apa yang anda ketahui tentang teknik dokumentasi !

2. Jelaskan apa yang anda ketahui tentang pengembangan sistem !

3. Uraikan 3 tingkatan pemahaman seseorang terhadap dokumentasi !

4. Sebut dan jelaskan 4 simbol yang digunakan dalam diagram arus data!

5. Uraikan manfaat diagram arus data dalam teknik pendokumentasian!

6. Sebut dan jelaskan 4 kategori simbol bagan alir !

7. Jelaskan keunggulan bagan alir dibandingkan dengan diagram arus data!

8. Jelaskan prinsip dasar pengembangan sistem !

9. Jelaskan tahapan utama siklus hidup pengembangan sistem !

10. Jelaskan mengapa perlu dilakukannya pengembangan sistem ! 


\section{Daftar Pustaka}

Fatta, H. Al, \& Marco, R. (2015). Analisis Pengembangan dan Perancangan Sistem Informasi Akademik Smart Berbasis Cloud Computing Pada Sekolah Menengah Umum Negeri (SMUN) di Daerah Istimewa Yogyakarta. Jurnal Telematika, Vol 8 No., 63.

Fatta, Hanif Al. (2007). Analisis dan Perancangan Sistem Informasi. Yogyakarta: Andi.

Romney, M. B., \& Steinbart, P. J. (2014). Accounting Information Systems. London: Prentice Hall. Widoyoko, E. P. (2015). Teknik Penyusunan Instrumen Penelitian. Yogyakarta: Pustaka Pelajar. 


\section{BAB 11}

\section{PENGENDALIAN DAN SISTEM INFORMASI AKUNTANSI}

\section{Tujuan instruksional}

Dengan membaca bab ini, mahasiswa diharapkan untuk mampu :

5. Memahami konsep pengendalian internal

6. Memahami dan menjelaskan kerangka pengendalian

7. Memahami dan menjelaskan aktivitas pengendalian

8. Memahami dan menjelaskan lingkungan internal pengendalian

\section{A. Pendahuluan}

Mengapa ancaman terhadap sistem informasi akuntansi meningkat? Karena beberapa kegagalan utama dalam mengendalikan keamanan dan integritas sistem komputer yakni informasi tersedia untuk sejumlah pekerja yang tidak pernah ada, pengendalian yang sulit terhadap informasi pada jaringan komputer, pihak luar seperti pelanggan dan pemasok memiliki akses ke sistem dan data satu sama lain.

Alasan-alasan dari organisasi yang belum melindungi data dengan baik : 
1. Perusahaan memandang kehilangan atas informasi penting merupakan sebuah ancaman yang tidak mungkin terjadi.

2. Pemahaman yang kurang terhadap implikasi pengendalian atas pemindahan dari sistem komputer tersentralisasi ke sistem berbasis internet.

3. Banyak perusahaan yang tidak menyadari bahwa informasi merupakan sebuah sumber daya strategi dan perlindungan informasi harus menjadi sebuah ketentuan strategis.

4. Mengabaikan ukuran-ukuran pengendalian yang memakan waktu pada produktivitas dan penekanan biaya.

\section{B. Konsep Pengendalian}

Pengendalian internal adalah suatu proses yang dijalankan oleh dewan komisaris, manajemen, dan personel lain dari suatu entitas yang didesain untuk memberikan keyakinan memadai tentang pencapaian tujuan berikut ini: (a) efektifitas dan efisiensi operasi, (b) keandalan laporan keuangan, dan (c) kepatuhan hukum dan peraturan yang berlaku (Tunggal, 2013). Menurut Mulyadi (2017) Pengendalian internal adalah rencana organisasi dan 
metode bisnis yang dipergunakan untuk menjaga aset, memberikan informasi yang akurat dan andal,mendorong dan memperbaiki efisiensi jalannya organisasi, serta mendorong kesesuaian dengan kebijakan yang telah ditetapkan.

Pengendalian internal (internal control) dilakukan untuk menjamin bahwa tujuan pengendalian akan dipenuhi. Tujuan-tujuan tersebut adalah:

1. Pengamanan aset untuk mencegah atau mendeteksi perolehan, penggunaan, atau penempatan aset yang tidak sah.

2. Pengelolaan catatan dengan detail dan baik untuk melaporkan aset-aset perusahaan secara akurat dan wajar.

3. Pemberian informasi yang sesuai, akurat, dan juga reliabel.

4. Penyediaan laporan keuangan yang sesuai dengan kriteria yang telah ditentukan.

5. Mendorong dan memperbaiki efisiensi kegiatan operasional.

6. Mendorong ketaatan terhadap kebijakan manajerial yang telah ditetapkan.

7. Mematuhi hukum dan aturan-aturan yang berlaku.

Menurut Arens, et al (2015) bahwa pengendalian internal memiliki tiga tujuan umum yang efektif yaitu: 
1. Reliabilitas pelaporan keuangan,

2. Efisiensi dan efektivitas operasi,

3. Ketaatan pada hukum dan peraturan

Fungsi penting yang dijalankan pengendalian internal:

1. Pengendalian preventif (preventive control) merupakan pengendalian yang mencegah suatu masalah sebelum masalah timbul. Contoh: merekrut personel/pegawai yang berkualifikasi, memisahkan tugas-tugas pegawai, dan mengendalikan akses fisik atas aset-aset dan informasi.

2. Pengendalian detektif (detective control) merupakan pengendalian yang dibuat untuk menemukan masalah dalam pengendalian yang tidak terelakkan. Contoh: duplikasi pengecekan kalkulasi dan menyiapkan rekonsiliasi bank serta neraca saldo tahunan.

3. Pengendalian korektif (corrective control) merupakan pengendalian yang mengidentifikasi dan memperbaiki masalah serta memulihkan dari kesalahan-kesalahan yang terjadi. Contoh: menjaga duplikasi backup pada file, perbaikan kesalahan memasukkan data, dan mengumpulkan ulang transaksi-transaksi untuk pemrosesan selanjutnya. 


\section{Kerangka Pengendalian}

terdapat tiga kerangka pengendalian untuk mengembangkan sistem pengendalian internal :

1. Kerangka Cobit

Control Objective for Information and Related Technology (COBIT) merupakan kerangka keamanan dan pengendalian yang memungkinkan :

a. manajemen untuk membuat tolak ukur praktik keamanan dan pengendalian dalam lingkungan $\mathrm{Tl}$;

b. para pengguna layanan TI diberikan jaminan dengan adanya keamanan dan pengendalian yang memadai;

c. para auditor memperkuat opini dalam pengendalian internal dan melakukan pertimbangan masalah keamanan $\mathrm{TI}$ dan pengendalian yang dilakukan.

5 prinsip utama tata kelola dan manajemen $\mathrm{TI}$ (COBIT 5):

a. Memenuhi keperluan para pihak yang berkepentingan.

b. Mencakup perusahaan dari ujung ke ujung.

c. Mengajukan kerangka yang terintegrasi dan tunggal.

d. Memungkinkan pendekatan holistik. 
e. Memisahkan tata kelola dari manajemen.

2. Kerangka Pengendalian Internal COSO

a. Committee of Sponsoring Organizations (COSO) merupakan kelompok dari sektor swasta yang terdiri atas Asosiasi Akuntansi Amerika (American Accounting Association), AICPA, Ikatan Auditor Internal (Institute of Management Accountans), serta Ikatan Eksekutif Keuangan (Financial Executives Institute).

b. Pengendalian Internal (Internal Control)Kerangka Terintegrasi-IC merupakan kerangka COSO yang menjelaskan mengenai pengendalian internal dan memberikan panduan dan instruksi untuk mengevaluasi dan meningkatkan sistem pengendalian internal.

3. Kerangka Manajemen Risiko Perusahaan COSO Manajemen Risiko Perusahaan (Enterprise Risk Management)- Kerangka Terintegrasi (Integrated Framework)-ERM merupakan kerangka cOSO yang memperbaiki proses manajemen risiko dengan memperluas (menambahkan tiga elemen tambahan) Pengendalian Internal COSOTerintegrasi. Prinsip-prinsip dasar dibalik ERM : 
a. Perusahaan dibentuk agar dapat menciptakan nilai bagi para pemiliknya.

b. Manajemen harus memutuskan jumlah ketidakpastian yang akan ia terima pada saat menciptakan nilai.

c. Ketidakpastian menghasilkan risiko, yang berarti bahwa sesuatu secara negatif kemungkinan mempengaruhi kemampuan perusahaan dalam menghasilkan atau mempertahankan nilai.

d. Ketidakpastian menghasilkan peluang, yang berarti bahwa sesuatu secara positif memungkinkan memengaruhi kemampuan perusahaan dalam menghasilkan atau mempertahankan nilai.

e. Kerangka ERM dapat mengelola ketidakpastian, menciptakan dan mempertahankan nilai.

\section{Aktivitas Pengendalian}

Aktivitas pengendalian (control activities) merupakan kebijakan, prosedur, dan aturan yang memberikan jaminan yang memadai bahwa tujuan pengendalian telah dicapai dan juga respons risiko telah dilakukan. Manajemen juga harus memastikan bahwa: 
1. Pengendalian yang dipilih dan dikembangkan bertujuan untuk membantu dalam pengurangan risiko hingga level yang dapat diterima

2. Pengendalian umum yang sesuai telah dipilih dan dikembangkan dengan teknologi

3. Aktivitas dalam pengendalian diimplementasikan dan dijalankan sesuai dengan kebijakan dan prosedur perusahaan yang sudah ditentukan.

Prosedur pengendalian dilakukan dalam kategori-kategori berikut:

1. Otorisasi transaksi dan aktivitas yang layak. a. Otorisasi (authorization): penetapan kebijakan bagi para pegawai untuk diikuti dan kemudian memberdayakan mereka guna melakukan fungsi organisasi tertentu. Otorisasi sering didokumentasikan dengan penandatanganan, penginisialisasian, atau pemasukan kode pengotorisasian pada sebuah dokumen atau catatan.

b. Tanda tangan digital (digital signature): cara penandatanganan sebuah dokumen secara elektronik dengan data yang tidak dapat dipalsukan. 
c. Otorisasi khusus (specific authorization): persetujuan khusus yang dibutuhkan oleh seorang pegawai agar diizinkan untuk menangani sebuah transaksi.

d. Otorisasi umum (general authorization): otorisasi yang diberikan kepada pegawai untuk menangani transaksi rutin tanpa persetujuan khusus.

2. Pemisahan tugas.

Pemisahan tugas terdiri dari beberapa jenis, yakni :

a. Pemisahan Tugas Akuntansi

Pemisahan tugas akuntansi (segregation of accounting duties) merupakan pemisahan dari fungsi akuntansi otorisasi, penyimpanan, dan pencatatan untuk meminimalkan kemampuan pegawai dalam melakukan tindakan penipuan. Pemisahan tugas akuntansi akan efektif apabila fungsifungsi berikut dipisahkan:

- Otorisasi - penyetujuan transaksi dan keputusan.

- Pencatatan - dokumen sumber disiapkan; data dimasukkan ke dalam sistem komputer, 
pemeliharaan jurnal, buku besar, file, atau database; dan juga mempersiapkan rekonsiliasi dan laporan kinerja.

- Penyimpanan - menangani kas, peralatan, persediaan, atau aktiva tetap; menerima cek dari pelanggan yang datang; menulis cek. Kolusi (collusion) merupakan kerja sama antara dua orang atau lebih yang berupaya untuk menggagalkan pengendalian internal.

b. Pemisahan Tugas Sistem

Pemisahan tugas sistem (segregation of system duties) merupakan penerapan dari prosedur-prosedur pengendalian dalam membagi wewenang dan tanggung jawab secara jelas pada fungsi sistem informasi. Wewenang dan tanggung jawab sebaiknya dibagi dengan jelas menurut fungsi-fungsi berikut:

- Administrator sistem (system administrator) yakni orang yang bertanggung jawab untuk 
memastikan sistem beroperasi berjalan dengan lancar dan efisien.

- Manajemen jaring (network manager) yakni orang yang bertanggung jawab untuk memastikan perangkat yang berlaku ditautkan ke jaringan perusahaan dan juga memastikan bahwa jaringan beroperasi dengan baik.

- Manajemen keamanan (security management) yakni orang yang bertanggung jawab untuk memastikan jika sistem yang ada telah aman dan terlindungi baik dari ancaman internal maupun eksternal.

- Manajemen perubahan (change management) yakni proses untuk memastikan bahwa perubahan dibuat dengan lancar dan efisien serta tidak akan mempengaruhi keterandalan, keamanan, kerahasiaan, integritas, dan ketersediaan sistem secara negatif.

- Pengguna (users) yakni orang yang melakukan pencatatan transaksi, 
melakukan otorisasi data untuk diproses dan juga menggunakan output sistem.

- Analisis sistem (system analysis) yakni orang yang membantu pengguna dalam menentukan kebutuhan informasi mereka dan mendesain sistem yang sesuai dengan kebutuhan tersebut.

- Pemrograman (programmer) yakni orang yang membuat desain analisis serta mengembangkan, mengodekan, dan menguji program komputer.

- Operasi komputer (computer operator) yakni orang yang akan mengoperasikan komputer perusahaan.

- Perpustakaan sistem informasi (information system library) yakni sebuah koleksi database, file, dan juga program perusahaan yang akan disimpan di dalam sebuah area penyimpanan terpisah dan dikelola oleh pustakawan sistem.

- Kelompok pengendalian data (data control group) yakni orang yang 
akan memastikan bahwa sumber data telah disetujui dengan semestinya, mengawasi alur kerja melalui komputer, merekonsiliasi input dan output, memelihara catatan input untuk memastikan kebenaran dan kepatuhannya kembali, serta mendistribusikan output sistem.

3. Pengembangan proyek dan pengendalian akuisisi (perolehan).

a. Komite pengarah (steering committee) merupakan sebuah komite tingkat eksekutif yang bertujuan untuk merencanakan dan mengawasi fungsi sistem informasi.

b. Rencana induk strategis (strategic master plan) merupakan sebuah rencana multi tahunan yang menjabarkan proyek perusahaan yang harus diselesaikan agar mencapai tujuan jangka panjangnya dan sumber daya yang dibutuhkan untuk mencapai rencana tersebut.

c. Rencana pengembangan proyek (project development plan) merupakan 
sebuah dokumen yang menunjukkan mengenai cara penyelesaian sebuah proyek.

d. Tonggak proyek (project milestones) merupakan poin-poin dari kemajuan yang ditinjau dan waktu penyelesaian aktual serta perkiraan dibandingkan.

e. Jadwal pengolahan data (data processing schedule) merupakan sebuah jadwal yang menunjukkan waktu pengerjaan dari tiap-tiap tugas pengolahan data.

f. Pengukuran kinerja sistem (system performance measurement) merupakan cara-cara dalam mengevaluasi dan menilai sebuah sistem.

g. Output per unit waktu (throughtput) merupakan jumlah pekerjaan yang harus dilakukan oleh sebuah sistem selama periode waktu tertentu.

h. Pemanfaatan (utilization) merupakan persentase waktu dalam penggunaan sebuah sistem.

i. Waktu respons (response time) merupakan lama waktu yang 
diperlukan oleh sebuah sistem untuk merespon.

j. Tinjauan pasca - implementasi (postimplementation review) merupakan tinjauan yang dilakukan guna memastikan hal itu sesuai dengan tujuan yang telah ditencanakan setelah sistem baru beroperasi untuk periode waktu yang singkat.

k. Sistem integrator (system integrator) merupakan pihak luar yang dipekerjakan untuk mengelola usaha dalam pengembangan sistem perusahaan. Perusahaan juga harus melakukan:

- Mengembangkan spesifikasi yang jelas.

- Mengawasi proyek.

4. Mengubah pengendalian manajemen.

Organisasi merubah sistem yang berjalan untuk merefleksikan praktik-praktik bisnis baru serta untuk memanfaatkan penggunaan TI.

5. Mendesain dan menggunakan dokumen serta catatan.

Desain dan penggunaan dokumen elektronik dan kertas yang tepat dapat membantu dalam 
memastikan pencatatan yang akurat serta lengkap dari seluruh data transaksi yang relevan.

6. Pengamanan aset, catatan, dan data.

Sebuah perusahaan harus melakukan perlindungan kas dan aset fisik beserta informasinya. Selain itu penting juga melakukan:

a. Menciptakan dan menegakkan kebijakankebijakan dan prosedur-prosedur yang tepat.

b. Memelihara catatan akurat dari seluruh asset yang ada.

c. Membatasi akses terhadap asset yang ada.

d. Melindungi catatan dan dokumen yang penting.

7. Pengecekan kinerja yang independen. Dilakukan dengan:

a. Tinjauan tingkat atas.

b. Tinjauan analitis

c. Rekonsiliasi catatan-catatan yang dikelola secara independen.

d. Perbandingan terhadap kuantitas aktual dengan jumlah dicatat.

e. Akuntansi double-entry.

f. Tinjauan independen. 


\section{E. Lingkungan Internal}

Lingkungan internal (internal environment) adalah budaya perusahaan yang menjadi fondasi dari seluruh elemen ERM lainnya, karena hal ini memengaruhi bagaimana cara organisasi dalam menetapkan strategi dan tujuannya; membuat struktur aktivitas; dan mengidentifikasi, menilai, serta merespons risiko. Lingkungan internal mencakup:

1. Filosofi Manajemen, Gaya Pengoperasian, dan Selera Risiko

Selera risiko (risk appetite) yakni jumlah risiko yang ingin diterima dari sebuah perusahaan untuk mencapai tujuan dan tujuannya. Untuk menghindari risiko yang tidak semestinya, maka selera risiko harus selaras dengan strategi perusahaan.

2. Komitmen Terhadap Integritas, Nilai Etis, dan Kompetensi

Perusahaan mendukung integritas dengan:

a. Mengajarkan serta mensyaratkannya secara aktif.

b. Menghindari pengharapan atau insentif yang tidak realistis.

c. Memberikan penghargaan terhadap kejujuran dan memberikan label verbal 
pada perilaku jujur dan tidak jujur secara konsisten.

d. Mengembangkan sebuah kode etik tertulis yang menjelaskan secara eksplisit mengenai perilaku-perilaku jujur dan tidak jujur.

e. Mewajibkan pegawai dalam melaporkan tindakan tidak jujur atau ilegal dan mendisiplinkan pegawai yang diketahui tidak melaporkannya.

f. Membuat sebuah komitmen untuk kompetensi.

3. Pengawasan Pengendalian Internal Oleh Dewan Direksi

Komite audit (audit committee) yakni sejumlah anggota dewan direksi yang berasal dari luar dan bersifat independen yang bertanggung jawab dalam pelaporan keuangan, kepatuhan terhadap peraturan, pengendalian internal, serta perekrutan dan pengawasan auditor internal dan eksternal.

4. Struktur Organisasi

Aspek-aspek penting dari struktur organisasi:

a. Sentralisasi atau desentralisasi wewenang. 
b. Hubungan pengarahan atau matriks pelaporan.

c. Organisasi berdasarkan industri, lini produk, lokasi, atau jaringan pemasaran.

d. Bagaimana alokasi tanggung jawab memengaruhi ketentuan informasi.

e. Organisasi dan garis wewenang untuk akuntansi, pengauditan, dan fungsi sistem informasi.

f. Ukuran dan jenis aktivitas perusahaan.

5. Metode Penetapan Wewenang dan Tanggung Jawab

Kebijakan dan prosedur manual (policy and procedures manual): sebuah dokumen yang menjelaskan praktik bisnis yang sesuai, mendeskripsikan pengetahuan dan pengalaman yang dibutuhkan, menjelaskan cara menangani transaksi serta mendata sumber daya yang tersedia untuk melaksanakan tugas-tugas tertentu.

6. Standar Sumber Daya Manusia yang Menarik, Mengembangkan, serta Mempertahankan Individu yang Kompeten Kekuatan pengendalian terbesar adalah kejujuran pegawai dan salah satu kelemahan pengendalian terbesar adalah ketidakjujuran 
pegawai. Dengan adanya kebijakan dan praktik-praktik yang mengatur kondisi kerja, maka insentif pekerjaan, dan kemajuan karier dapat menjadi kekuatan untuk mendorong kejujuran, efisiensi, dan layanan yang loyal dari pegawai. Untuk mendapatkan individu yang kompeten maka diperlukan:

a. Perekrutan

Pengecekan latar belakang para pegawai atau calon pegawai yang memasukkan verifikasi pendidikan dan pengalaman kerja mereka, berbicara berdasarkan referensi, pengecekan catatan kriminal atau masalah kredit, serta pemeriksaan informasi lain yang tersedia secara publik.

b. Mengompensasi, Mengevaluasi, dan Mempromosikan

Pembayaran upah / gaji yang wajar dan insentif bonus yang sesuai dapat membantu memotivasi dan memperkuat kinerja pegawai yang hebat. Para pegawai yang diberi penilaian kinerja periodik dapat membantu mereka dalam memahami kekuatan dan kelemahan mereka.

c. Pelatihan 
Pelatihan penting untuk dilakukan mengajarkan pegawai baru akan tanggung jawab mereka.

d. Pengelolaan Para Pegawai yang Tidak Puas

Perusahaan membutuhkan prosedur untuk mengidentifikasi para pegawai yang merasa tidak puas dan membantu mereka dalam mengatasi perasaan itu untuk memindahkan mereka dari pekerjaan yang sensitif.

e. Pemberhentian

Pegawai yang diberhentikan harus segera dipindahkan dari pekerjaan yang sensitif dan menolak aksesnya ke dalam sistem informasi.

f. Liburan dan Rotasi Kerja

Melakukan rotasi tugas pegawai secara periodik serta membuat pegawai mengambil liburan dapat membantu mencapai kepuasan pegawai sehingga pegawai juga akan melakukan yang terbaik dalam kinerjanya. 
g. Perjanjian Kerahasiaan dan Asuransi Ikatan Kesetiaan

Seluruh pegawai, pemasok, dan kontraktor harus menandatangani serta mematuhi sebuah perjanjian kerahasiaan. Asuransi ikatan kesetiaan melingkupi para pegawai merupakan kunci yang melindungi perusahaan dari kerugian yang timbul akibat tindakan penipuan yang disengaja.

h. Menuntut dan Memenjarakan Pelaku Perusahaan harus berani dalam membuat kebijakan dalam menuntut dan memenjarakan pelaku penipuan. Sebagian besar penipuan tidak dilaporkan karena:

- Perusahaan segan untuk melaporkan penipuan karena dapat merusak nama baik dan menjadi sebuah bencana hubungan publik.

- Penegak hukum dan pengadilan lebih sibuk dengan kasus kriminal kekerasan dibandingkan dengan penipuan.

- Sulitnya melakukan penyelidikan dan menuntut penipuan karena membutuhkan biaya, dan memakan waktu. 
- Banyak oknum petugas penegak hukum, pengacara dan hakim yang kurang memiliki kecakapan dalam komputer yang diperlukan untuk menyelidiki dan menuntut kejahatan komputer.

- Hukuman bagi penipu untuk kasus penipuan biasanya ringan.

\section{Pengaruh Eksternal}

Pengaruh eksternal dapat meliputi persyaratan-persyaratan yang diajukan oleh bursa efek, Financial Accounting Standars Board (FASB), PCAOB, dan SEC.

\section{Kesimpulan}

Pengendalian internal (internal control) merupakan proses dan prosedur yang dijalankan agar dapat menyediakan jaminan yang memadai dan memastikan bahwa tujuan pengendalian dipenuhi. Pengendalian internal menjalankan tiga fungsi penting yakni pengendalian preventif, pengendalian detektif, dan pengendalian korektif . Ada tiga kerangka pengendalian untuk mengembangkan sistem pengendalian internal yakni kerangka COBIT, kerangka pengendalian internal COSO, dan kerangka manajemen risiko perusahaan coso. 
Aktivitas pengendalian (control activities) merupakan kebijakan, prosedur, dan aturan yang memberikan jaminan yang memadai bahwa tujuan dari pengendalian telah dicapai dan respon risiko telah dilakukan. Manajemen juga harus memastikan bahwa pengendalian yang dipilih dan dikembangkan dalam membantu mengurangi risiko hingga level yang dapat diterima, pengendalian umum yang sesuai dipilih dan dikembangkan melalui teknologi, aktivitas pengendalian diimplementasikan dan dijalankan telah sesuai dengan kebijakan dan prosedur perusahaan yang sudah ditentukan.

Lingkungan internal (internal environment) merupakan budaya perusahaan yang menjadi fondasi dari seluruh elemen ERM lainnya karena dapat memengaruhi bagaimana cara organisasi dalam menetapkan strategi dan tujuannya; membuat struktur aktivitas; dan mengidentifikasi, menilai, serta merespons risiko. Sebuah lingkungan internal biasanya mencakup filosofi manajemen, gaya pengoperasian, selera risiko, komitmen terhadap integritas, nilai-nilai etis, serta kompentensi, pengawasan pengendalian internal oleh dewan direksi, struktur organisasi, metode penetapan wewenang dan tanggung jawab, standar-standar 
sumber daya manusia yang menarik, mengembangkan, dan mempertahankan individu yang kompeten dan pengaruh eksternal.

\section{SOAL}

1. Jelaskan apa yang anda ketahui tentang pengendalian internal!

2. Jelaskan apa sajakan keterbatasan pengendalian internal!

3. Jelaskan apa sajakah yang menjadi komponen pengendalian internal !

4. Jelaskan tujuan pengendalian internal!

5. Jelaskan bagaimana kerangka pengendalian internal !

6. Jelaskan bagaimana cara mengimplementasikan pengendalian internal dalam sebuah perusahaan !

7. Jelaskan apa saja aktivitas dalam pengendalian internal!

8. Jika pengendalian internal berjalan dengan baik, apa saja keuntungan yang diperoleh perusahaan? jelaskan!

9. Jelaskan pengaruh eksternal dalam pengendalian internal! 
10. Apabila salah satu unsur sistem informasi akuntansi tidak berjalan dengan baik apakah pengendalian internal masih berjalan dengan baik? jelaskan!

\section{Daftar Pustaka}

Arens, A. A., Elder, R. J., \& Beasley, M. S. (2015).

Auditing \& Jasa Assurance. Jakarta: Salemba Empat.

Mulyadi. (2017). Sistem Akuntansi. Jakarta: Salemba Empat.

Tunggal, A. W. (2013). The Fraud Audit: Mencegah dan

Mendeteksi Kecurangan Akuntansi. Jakarta:

Harvarindo. 


\section{DAFTAR PUSTAKA}

Arens, A. A., Elder, R. J., \& Beasley, M. S. (2015). Auditing \& Jasa Assurance. Jakarta: Salemba Empat.

Azhar, S. (2002). Sistem Informasi Manajemen : Konsep dan Pengembangannya. Bandung: Lingga Jaya.

Azhar, S. (2017). Sistem Informasi Akuntansi. Bandung: Lingga Jaya.

Baridwan, Z. (1996). Sistem Informasi Akuntansi. Yogyakarta: BPFE.

Bodnar, G. H., \& Hopwood, W. S. (2010). Accounting Information System. United State of America: Pearson Education Inc.

Connolly, T., \& Begg, C. (2015). Database Systems A Practical Approach to Design, Implementation, and Management. Harlow: Pearson Education Limited. Connolly, T. M., \& Begg, C. E. (2005). Database System : A Practical Approach to Design, Implementation, and Management. United State of America: Education Limited.

Fatta, H. Al, \& Marco, R. (2015). Analisis Pengembangan dan Perancangan Sistem Informasi Akademik Smart Berbasis Cloud Computing Pada Sekolah Menengah Umum Negeri (SMUN) di Daerah Istimewa Yogyakarta. Jurnal Telematika, Vol 8 No., 63.

Fatta, Hanif Al. (2007). Analisis dan Perancangan Sistem Informasi. Yogyakarta: Andi.

Hall, J. A. (2007). Sistem Informasi Akuntansi. Jakarta: Salemba Empat.

Hanafi, M. M., \& Halim, A. (2014). Analisis Laporan 
Keuangan. Yogyakarta: UPP AMP YKPN.

Hapsari, R. (2019). Sistem Manajemen Basis Data.

Hasibuan, M. S. P. (2002). Manajemen Sumber Daya

Manusia. Jakarta: PT. Bumi Perkasa.

Jay, H., \& Barry, R. (2005). Operations Management. Jakarta: Salemba Empat.

Jogiyanto. (2005). Analisis \& Desain Sistem Informasi :

pendekatan terstruktur teori dan praktek aplikasi

bisnis. Yogyakarta: Andi.

Kadir, A. (2001). Dasar Pemrograman Web Dinamis Menggunakan PHP. Yogyakarta: Andi.

Kotler, \& Keller. (2009). Manajemen Pemasaran. Jakarta:

Erlangga.

Kotler, P. (2005). Manajemen Pemasaran. Jakarta:

Prenhalindo.

Laudon, K. C., \& Laudon, J. P. (2008). Sistem Informasi

Manajemen. Jakarta: Salemba Empat.

McLeod. (2004). Sistem Informasi Manajemen. Jakarta:

PT. Indeks.

Mcleod, J. R., \& Schell, G. (2001). Management

Information System. New Jersey: Prentice Hall International Inc.

Mulyadi. (2017). Sistem Akuntansi. Jakarta: Salemba Empat.

Mulyani, S. (2016). Metode Analisis dan Perancangan

Sistem. Bandung: Abdi Sistematika.

O’Brien, J. A., \& George M Marakas. (2016). Analisa

Sistem Informasi (1st ed.). Yogyakarta: Andi.

Oetomo, B. S. D. (2002). Perencanaan dan Pembangunan

Sistem Informasi. Yogyakarta: Andi. 
Rivai, V. (2009). Manajemen Sumber Daya Manusia Untuk Perusahaan Dari Teori ke Praktik. Jakarta: Raja Grafindo Persada.

Rochaety, E., Setyowati, T., \& Ridwan, F. (2011). Sistem Informasi Manajemen. Jakarta: Mitra Wacana Media.

Romney, M. B., \& Steinbart, P. J. (2012). Accounting Information System. London: Prentice Hall.

Romney, M. B., \& Steinbart, P. J. (2014). Accounting Information Systems. London: Prentice Hall.

Sprague, R. H., \& Watson, H. J. (1993). Decision Support

Systems: Putting Theory Into Practice. New Jersey:

Prentice Hall.

Tunggal, A. W. (2013). The Fraud Audit: Mencegah dan

Mendeteksi Kecurangan Akuntansi. Jakarta:

Harvarindo.

Turban, E., \& Aronson, J. E. (2001). Decision Support

Systems and Intelligent Systems. Upper Saddle River, NJ: Prentice Hall.

Widoyoko, E. P. (2015). Teknik Penyusunan Instrumen

Penelitian. Yogyakarta: Pustaka Pelajar.

Wignjosoebroto, S. (2006). Pengantar Teknik dan

Manajemen Industri. Surabaya: Guna Widya. 


\section{BIODATA PENULIS}

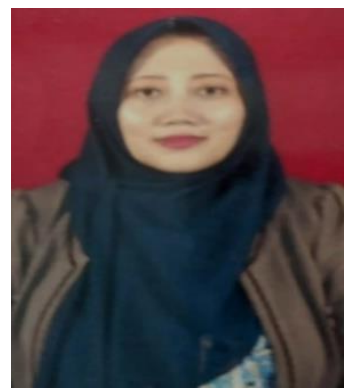

Imelda

Dian

Rahmawati.,

SE.Ak.M.Ak.CA lahir di Sidoarjo, 13

Oktober 1978. Menyelesaikan studi S1 di Universitas Brawijaya Malang pada program studi akuntansi pada tahun 2002. Studi S2 diselesaikan pada tahun 2010 pada program Magister Akuntansi Universitas Airlangga Surabaya dan pada saat ini sedang menyelesaikan pada studi doctoral akuntansi pada universitas yang sama. Penulis terdaftar sebagai dosen tetap universitas Muhammadiyah sidoarjo pada tahun 2002. Penulis terlibat sebagai peneliti, abdimas dan pembicara di berbagai seminar dan workshop yang diselenggarakan instansi pemerintah maupun non pemerintah.

Ir. Sumarno, MM. lahir di Sidoarjo, 27 Mei 1961. Beliau aktif dalam tri dharma Perguruan Tinggi, baik pengajaran, penelitian, maupun pengabdian masyarakat baik yang didanai internal UMSIDA maupun DIKTI.

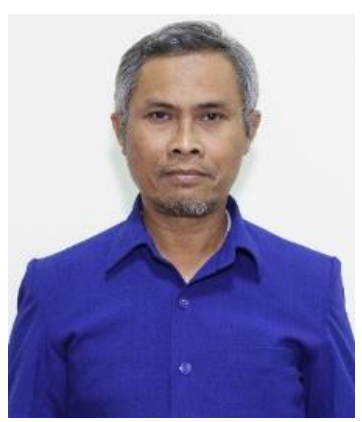


